PAULA CHRISTINA GONZALES PRAXEDES

Aspectos da qualidade higiênico-sanitária de alimentos consumidos e comercializados na comunidade São Remo, São Paulo, Capital. 


\section{ASPECTOS DA QUALIDADE HIGIÊNICO-SANITÁRIA DE ALIMENTOS CONSUMIDOS E COMERCIALIZADOS NA COMUNIDADE SÃO REMO, SÃO PAULO, CAPITAL}

Dissertação apresentada ao Programa de Pós Graduação em Epidemiologia Experimental e Aplicada às zoonoses para obtenção do titulo de Mestre, junto à Faculdade de Medicina Veterinária e Zootecnia da Universidade de São Paulo.

Departamento:

Medicina Veterinária Preventiva e Saúde Animal

Área de Concentração:

Epidemiologia Experimental e aplicada ao controle das Zoonoses.

Orientadora:

Profa. Dra. Simone de Carvalho Balian 
Autorizo a reprodução parcial ou total desta obra, para fins acadêmicos, desde que citada a fonte.

DADOS INTERNACIONAIS DE CATALOGAÇÃO-NA-PUBLICAÇÃO

(Biblioteca da Faculdade de Medicina Veterinária e Zootecnia da Universidade de São Paulo)

T.1312

FMVZ
Praxedes, Paula Christina Gonzales

Aspectos da qualidade higiênico-sanitária de alimentos consumidos e comercializados na comunidade São Remo, São Paulo, Capital / Paula Christina Gonzales Praxedes - São Paulo : P. C. G. Praxedes, 2003.

$$
120 \mathrm{f} \text { : : il. }
$$

Dissertação (mestrado) - Universidade de São Paulo. Faculdade de Medicina Veterinária e Zootecnia. Departamento de Medicina Veterinária Preventiva e Saúde Animal, 2003.

Programa de Pós-graduação: Epidemiologia Experimental e Aplicada às Zoonoses.

Área de concentração: Epidemiologia Experimental e Aplicada às Zoonoses.

Orientador: Profa. Dra. Simone de Carvalho Balian.

1. Alimentos. 2. Bactérias. 3. Manipuladores (treinamento). 4. Higiene. 5. Educação em saúde. I. Título. 


\section{FOLHA DE AVALIAÇÃO}

Nome da autora: PRAXEDES, Paula Christina Gonzales

Título: Aspectos da qualidade higiênico-sanitária de alimentos consumidos e comercializados na comunidade São Remo, São Paulo, Capital

Dissertação apresentada para obtenção de titulo de Mestre, junto à Faculdade de Medicina Veterinária e Zootecnia da Universidade de São Paulo.

Data:

\section{Banca Examinadora}

Prof. Dr. Instituição:

Assinatura: Julgamento:

Prof. Dr. Instituição:

Assinatura: Julgamento:

Prof. Dr. Instituição:

Assinatura: Julgamento: 


\section{DEDICATÓRIA}

À Reinará, que conseguiu me apressar e fazer esse trabalho nascer antes dela! Ao Fernando, meu amor, por todo apoio, principalmente nos dia de desânimo... Aos meus pais, que me apoiaram em tudo o que eu decidi fazer, Aos meus irmãos, avós, tios, tias, primos e primas, Aos moradores da São Remo, Aos brasileiros que esperam e lutam para ter um País melhor! 


\section{AGRADECIMENTOS}

À minha orientadora Profa. Dra.Simone de Carvalho Balian pelo apoio a um projeto tão alternativo.

Às Profas. Dras. Evelise O. T. Ramos e Sônia Regina Pinheiro pelas orientações e atenções que me dedicaram.

Ao pessoal da biblioteca da FMVZ-USP pelas orientações, atenção, paciência e eficiência.

A todos do Laboratório de Bioestatística, em especial Fernando Ferreira e Ricardo Augusto Dias pelo apoio estatístico fundamental.

Ao Bispo e Sandrinha por tudo!

A todos do VPS, docentes, residentes, funcionários e pós-graduandos pelos encontros e conversas de corredor.

A todos os graduandos da 67,65,64, 63 e Equipe 66 que voluntariamente me ajudaram a realizar as entrevistas, em especial ao Zorba (65), por comparecer até o fim, inclusive em dias de chuva!

Aos moradores e proprietários de estabelecimentos de alimentos da Comunidade São Remo, por terem sido tão receptivos e porque sem eles esse trabalho não existiria!

Ao Didi Jackson, Presidente da Associação de Moradores da Comunidade São Remo em 2001, pelo apoio ao projeto.

A VET 62, a melhor turma dessa Faculdade! 
"Quem me dera, ao menos uma vez, que o mais simples fosse visto como o mais importante..." 


\section{RESUMO}

PRAXEDES, P. C. G., Aspectos da qualidade higiênico-sanitária de alimentos consumidos e comercializados na comunidade São Remo, São Paulo, Capital. [Foodsafety aspects about consumed and comercialized food at São Remo Community, São Paulo, Capital]. 2003. 120 f. Dissertação (Mestrado em Epidemiologia Experimental e Aplicada às Zoonoses) - Faculdade de Medicina Veterinária e Zootecnia, Universidade de São Paulo, São Paulo, 2003.

A segurança alimentar é um tema que está ganhando importância a cada dia. A ocorrência de casos e surtos de doenças transmitidas por alimentos é grande e traz prejuízos tanto à saúde quanto à economia. O presente trabalho tem por objetivos levantar alguns aspectos da qualidade higiênico-sanitária e do padrão de consumo de alimentos na comunidade São Remo, São Paulo, Capital, no que se refere aos conhecimentos e hábitos higiênicos em relação aos alimentos. Foram colhidas amostras de alimentos para análise microbiologia e realizadas entrevistas com os moradores da Comunidade e com os comerciantes de alimentos da mesma área. Constatou-se a existência de alimentos com risco de intoxicação alimentar e a falta de informação aprofundada sobre os microrganismos e sobre como evitar sua multiplicação no ambiente da cozinha. Concluiu-se que há necessidade de treinamento dos comerciantes e da população priorizando a características da Comunidade e participação da população.

Palavras-chave: Alimentos, Bactérias, Educação em saúde, Higiene, Manipuladores (treinamento). 


\begin{abstract}
PRAXEDES, P. C. G. Food-safety aspects about consumed and comercialized food at São Remo Community, São Paulo, Capital. [Aspectos da qualidade higiênico-sanitária de alimentos consumidos e comercializados na comunidade São Remo, São Paulo, Capital].2003. 120 f. Dissertação (Mestrado em Epidemiologia Experimental e Aplicada às Zoonoses)- Faculdade de Medicina Veterinária e Zootecnia, Universidade de São Paulo, São Paulo, 2003.
\end{abstract}

Food safety is a very serious issue and it is gaining more and more importance every day. The number of single cases and outbreaks of food borne diseases is high as are high the costs to health and economy generated by it. The aim of this study is to bring to light aspects of food-safety, hygiene as well as the standards of food consumed at São Remo Community, São Paulo, Capital. Samples of food were collected for microbiological analysis and interviews were carried out with inhabitants along with traders of the community. The survey not only found a real threat of food poisoning but also a deep lack of information about microorganisms and how to avoid their multiplication in a kitchen environment. It was concluded that training should be given to the population and to anyone somehow related to the food business. This training should priorize popular attendance and respect and understand the characteristics of the Community.

Key-words: Health education, Food, Bacteria, Hygiene, Food-handlers (training). 


\section{LISTA DE GRÁFICOS}

Gráfico 1- Idade dos entrevistados, homens e mulheres, proprietários de estabelecimentos de alimentos na comunidade São Remo, São Paulo, 2001.

Gráfico 2- Nível de escolaridade dos entrevistados, homens e mulheres, nos estabelecimentos de alimentos da comunidade São Remo, São Paulo, 2001.

Gráfico 3- Experiências anteriores: Estabelecimentos de alimentos onde os proprietários já trabalharam. São Paulo, 2001.

Gráfico 4- Estabelecimentos que comercializam alimentos existentes na Comunidade São Remo, separados por tipo. São Paulo, 2001.

Gráfico 5- Tipos de alimentos comercializados nos estabelecimentos da Comunidade São Remo, São Paulo, 2001.

Gráfico 6- Número de funcionários dos estabelecimentos entrevistados na Comunidade São Remo, São Paulo, 2001.

Gráfico 7- Critérios utilizados para a aquisição de matérias primas pelos comerciantes da Comunidade São Remo, São Paulo, 2001.

Gráfico 8- Causas relatadas pelos comerciantes de alimentos da Comunidade São Remo para a devolução de produtos alimentícios, São Paulo, 2001.

Gráfico 9- Situações e procedimentos relatados pelos proprietários de estabelecimentos de alimentos, como responsáveis por situações onde os alimentos podem causar danos à saúde do consumidor, São Paulo, 2001.

Gráfico 10- Principal cuidado que o proprietário de estabelecimento de alimentos tem na hora de cozinhar, São Paulo, 2001.

Gráfico 11- Produtos utilizados para a limpeza e desinfecção dos utensílios, piso e banheiros nos estabelecimentos de alimentos da Comunidade São Remo. São Paulo, 2001. 
Gráfico 12- Locais onde as bactérias podem ser encontradas segundo os comerciantes da Comunidade São Remo.

São Paulo, 2001.

Gráfico 13- Formas para destruir as bactérias na opinião dos comerciantes de alimentos da Comunidade São Remo. São Paulo, 2001.

Gráfico 14- Alterações que os proprietários gostariam de fazer em seus estabelecimentos, São Remo, São Paulo, 2001.

Gráfico 15- Opinião dos comerciantes da Comunidade São Remo sobre para o que serve as análises realizadas nos alimentos. São Paulo, 2001.

Gráfico 16- Caracterização dos moradores da Comunidade São Remo quanto à idade. São Paulo, 2001.

Gráfico 17- Grau de instrução da população entrevistados na Comunidade São Remo, São Paulo, 2001.

Gráfico 18- Ocupação dos entrevistados na Comunidade São Remo. São Paulo, 2001.

Gráfico 19- Número de pessoas que residem nos domicílios entrevistados da Comunidade São Remo, São Paulo, 2001.

Gráfico 20- Local onde a população entrevistada da Comunidade São Remo adquire os alimentos. São Paulo, 2001.

Gráfico 21- Características observadas no rótulo das mercadorias compradas pelos moradores da Comunidade São Remo, São Paulo, 2001.

Gráfico 22- Alimentos que já foram desprezados por algum motivo pelos moradores da Comunidade São Remo, São Paulo, 2001.

Gráfico 23- Razões pelas quais os alimentos estragam, segundo os entrevistados na Comunidade São Remo, São Paulo, 2001.

Gráfico 24- Alimentos que estragam mais rápido, segundo os entrevistados da Comunidade São Remo, São Paulo, 2001.

Gráfico 25- Razão pela qual alguns alimentos estragam mais rápido que outros, segundo a população entrevistada na Comunidade São Remo, São Paulo, 2001. 
Gráfico 26- O que é considerado falta de higiene, na opinião dos moradores da Comunidade São Remo, São Paulo, 2001.

Gráfico 27- Alimentos suspeitos de terem causado intoxicação alimentar nos entrevistados da Comunidade São Remo, São Paulo, 2001.

Gráfico 28- Locais onde os alimentos suspeitos de terem causado intoxicação alimentar foram ingeridos. São Paulo, 2001.

Gráfico 29- Sintomas apresentados após a ingestão de alimentos suspeitos. São Paulo, 2001.

Gráfico 30- Palavras que vem à cabeça dos entrevistados quando pensam em bactérias. São Paulo, 2001.

Gráfico 31- Locais onde as bactérias podem ser encontradas, segundo os moradores da Comunidade São Remo, São Paulo, 2001.

Gráfico 32- Formas de destruir as bactérias de acordo com os locais onde se encontram, segundo os moradores entrevistados da Comunidade São Remo, São Paulo, 2001.

Gráfico 33- Razões pelas quais o alimento pode estar estragado sem ter qualquer alteração organoléptica, na opinião dos moradores da Comunidade São Remo, São Paulo, 2001.

Gráfico 34- Principais cuidados que os entrevistados tem na hora de cozinhar. São Paulo, 2001.

Gráfico 35- Doenças que podem ser transmitidas pelos alimentos, segundo a população da Comunidade São Remo, São Paulo, 2001.

Gráfico 36- Como evitar as doenças transmitidas pelos alimentos de acordo com os moradores da Comunidade São Remo, São Paulo, 2001.

Gráfico 37- Alimentos que os entrevistados consideram perigosos. São Paulo, 2001.

Gráfico 38- Veículos de comunicação utilizados pelos entrevistados para obter informação, na Comunidade São Remo, São Paulo, 2001. 
Gráfico 39- Melhor forma de aprofundar os conhecimentos sobre higiene de alimentos na Comunidade São

Remo, São Paulo, 2001. 


\section{LISTA DE FIGURAS}

Figura 1- Delimitações da Comunidade São Remo e Região onde está localizada. São Paulo, 2002.

Figura 2- Estabelecimentos onde foram obtidas amostras e os tipos de alimentos colhidos para análise microbiológica . São Paulo, 2001. 


\section{LISTA DE TABELAS}

Tabela 1- Alimentos colhidos para análise microbiológica separados por tipo e por tipo de análise realizada, São Paulo, 2001

Tabela 2- Temas relevantes para os funcionários que manipulam alimentos citados pelos proprietários de estabelecimentos que comercializam alimentos na Comunidade São Remo,São Paulo, 2001

Tabela 3- Palavras associadas às bactérias de acordo com os proprietários de estabelecimentos da Comunidade São Remo. São Paulo, 2001

Tabela 4- Problemas na Comunidade enfrentados pelos proprietários de estabelecimentos da Comunidade São Remo. São Paulo, 2001

Tabela 5-Soluções apontadas pelos proprietários de estabelecimentos da Comunidade São Remo. São Paulo, 2001

Tabela 6- Principais problemas existentes na Comunidade São Remo segundo os moradores. São Paulo, 2001

Tabela 7- Soluções apontadas pelos moradores para os problemas existentes na Comunidade São Remo São Paulo, 2001

Tabela 8- Dúvidas apontadas pelos moradores sobre a questão dos alimentos. São Remo, 2001.

Tabela 9- Características do armazenamento dos alimentos in natura nos estabelecimentos de alimentos da Comunidade São Remo. São Paulo, 2001

Tabela 10- Características do armazenamento dos alimentos prontos para o consumo nos estabelecimentos. São Paulo, 2001

Tabela 11- Resultado das análises feitas em amostras de Carne Seca, São Paulo, 2001

Tabela 12- Resultados das análises feitas em amostras de Requeijão do Norte, São Paulo, 2001

Tabela 13- Resultados da pesquisa de Coliformes totais e fecais (NMP/g) realizadas nas amostras dos demais alimentos in natura.São Paulo, 2001 
Tabela 14- Resultado das análises realizadas em alimentos preparados, São Paulo, 2001 
SUMÁRIO

1. INTRODUÇÃO................................................................................................18

2. REVISÃO DE LITERATURA............................................................

3. MATERIAL E MÉTODOS...................................................................32

3.1 MODALIDADE DE PESQUISA....................................................................32

3.2 LOCALIZAÇÃO DA COMUNIDADE.........................................................33

3.3 ESTUDO DESCRITIVO..................................................................................33

3.4 ANÁLISE MICROBIOLÓGICA DOS ALIMENTOS...................................39

4. RESULTADOS E DISCUSSÃO.................................................................42

4.1 ENTREVISTA COM A POPULAÇÃO DA COMUNIDADE....................42

4.2 ENTREVISTA COM OS COMERCIANTES DE ALIMENTOS.............70

4.3 ANÁLISE MICROBIOLÓGICA DOS ALIMENTOS................................97

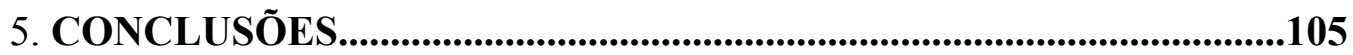

REFERÊNCIAS............................................................................................108

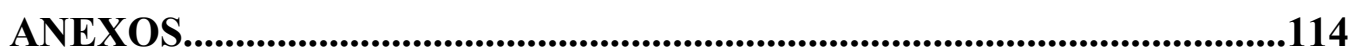




\section{INTRODUÇÃO}

Nos últimos anos, diversos eventos têm ocorrido no cenário internacional e chamam a atenção para a segurança alimentar na saúde e o desenvolvimento humano. Um exemplo é a Conferência Internacional em Nutrição da FAO/OMS (Organização Mundial de Saúde), ocorrida em 1992, que reconheceu que o acesso ao alimento nutricionalmente adequado e seguro é um direito de todo o indivíduo e apontou que centenas de milhares de pessoas sofrem de doenças causadas por alimentos DTAs ou pela água contaminada. (WHO, 2001).

Alimentos de origem animal, como carnes e derivados, ovos, leite e seus derivados são os mais freqüentemente envolvidos em DTAs. Os agentes patogênicos veiculados por esses alimentos são na sua maioria bactérias: Salmonella spp. Staphylococcus aureus, Escherichia coli, Clostridium perfringens, Bacillus cereus, Campylobacter jejuni entre outros. Dados da Vigilância sanitária do Paraná revelam que tem havido um grande número de surtos em domicílios e nos restaurantes e que tais números são ainda subestimados, dada a deficiente notificação das ocorrências (GERMANO, 2001). Na maioria destes surtos a contaminação dos alimentos se dá pela manipulação inadequada e pelo armazenamento incorreto. Hábitos como a má higienização das mãos antes do preparo dos alimentos; o cozimento inadequado, o armazenamento sob temperaturas incorretas e a aquisição de produtos de origem desconhecida ou duvidosa (produtos sem identificação, data de fabricação e validade) são algumas das situações mais freqüentes que colocam o alimento e a saúde do consumidor em risco (GERMANO, 2001). 
Para minimizar estes riscos, a atuação dos serviços de saúde e vigilância são de suma importância e a inclusão de projetos educativos nesse setor é indispensável. Isso porque a maioria das situações acima descritas ocorre pela falta de informação do manipulador a respeito das causas e conseqüências da manipulação inadequada dos alimentos. O desenvolvimento de uma postura crítica como consumidor também é fundamental para atingir a produção de alimentos seguros e depende fundamentalmente de investimentos em educação. Qualquer projeto educativo somente será eficaz se levar à conscientização da população e sua real mudança de atitude, promovendo a inocuidade dos alimentos.

Para que um projeto educativo seja eficiente é necessário conhecer o públicoalvo, identificando o conhecimento prévio que este traz em relação ao assunto, seu grau de preocupação sobre as questões abordadas e o interesse que demonstra em receber informações novas, entre outros aspectos.

Quando se toma como alvo uma comunidade carente, são vários os fatores que dificultam as práticas de higiene, abrangendo aspectos como o saneamento básico, o controle de animais sinantrópicos e a salubridade das moradias. A precariedade desses fatores aumenta o risco de contaminação dos alimentos e a ocorrência de DTAs.

Associado à isso, a falta de informação sobre a relação alimento-doença contribui fortemente para a ocorrência de casos e surtos de DTAs. Isso evidencia a necessidade e importância do desenvolvimento de trabalhos que tenham por objetivo definir as relações estabelecidas entre pessoas, alimento e meio ambiente, suas crenças e hábitos em relação aos alimentos, quais as possíveis formas de incrementar a qualidade de vida da população e reduzir o risco de ocorrência de DTAs e quais os meios de comunicação mais aceitos para serem utilizados nesse processo. 
Análises microbiológicas são importantes recursos para monitorar as condições higiênicas e sanitárias de equipamentos e utensílios que entram em contato com os alimentos e também dos manipuladores de alimentos (FRANCO, 1992).

Sob estes critérios, o presente trabalho tem por objetivo determinar alguns aspectos relativos à qualidade higiênico-sanitária e ao padrão de consumo de alimentos na comunidade São Remo, São Paulo (Capital), servindo como subsídio para elaboração de um diagnóstico educativo a respeito de higiene de alimentos, visando conhecer a população e os comerciantes de alimentos desta comunidade. 


\section{REVISÃO DE LITERATURA}

O interesse público em relação aos alimentos transgênicos, irradiação, resíduos químicos nos alimentos e o possível risco de transmissão da doença da "vaca louca" pela ingestão de carne vem crescendo nos últimos anos e mantendo o tema alimento e saúde constantemente em destaque (KÄFERSTEIN; ABDUSSALAM, 1999).

O crescimento urbano desordenado, a resistência microbiana aos antibióticos e a diminuição do suprimento de alimento e água às populações são exemplos das mudanças globais que o mundo está sofrendo no século 21 e que devem merecer maior atenção pelas organizações nacionais e internacionais (KÄFERSTEIN; ABDUSSALAM, 1999).

A Organização Mundial da Saúde (OMS) relata que as doenças de origem alimentar são consideradas o maior problema de saúde pública em todo o mundo (CALIFANO, 2000; MUSAIGER,1995). Diarréia de origem alimentar e hídrica continua sendo a causa mais comum de doença na infância e também a causa mais freqüente de mortalidade infantil nos países em desenvolvimento. A Organização Mundial da Saúde reportou que em 1998, 1,8 milhões de crianças morreram devido à diarréia. Contribui para esse quadro a desnutrição, com graves conseqüências para o crescimento e a resistência das crianças. Entre 12 a 13 milhões de crianças morrem por ano no mundo em virtude dessa combinação diarréia $\mathrm{X}$ desnutrição (CALIFANO, 2000).

De acordo com a Organização Mundial da Saúde (OMS), a Segurança Alimentar deve assegurar que toda a população disponha de acesso físico e econômico a alimentos inócuos e nutritivos, que permitam manter uma vida sadia, ativa e 
plenamente produtiva. (OPAS/OMS, 2001). Já o conceito brasileiro de segurança alimentar, elaborado em Julho de 1994 na I Conferência Nacional de Segurança Alimentar, enfatiza que deve ser garantido o acesso aos alimentos para todas as pessoas, todos os dias, em quantidade suficiente (incluindo energia, proteínas e micronutrientes) para assegurar uma vida ativa e saudável, contemplando ainda o acesso suficiente, regular e a baixo custo dos alimentos básicos, simultaneamente à melhoria das condições de vida e ao acesso à informação (SESC, 1999).

Os direitos dos consumidores, ao mesmo tempo, incluem, entre outros, o direito de ter uma oferta suficiente de alimentos adequados, inócuos, de boa qualidade e a preços competitivos. Também se consideram direitos do consumidor o de receber uma adequada informação sobre os componentes, quantidade, qualidade e riscos para a saúde, bem como orientações para manter uma dieta sadia e equilibrada (NIELLO, 2001). No artigo sexto, item III da Lei 8.078/90 (BRASIL, 1990), constam como direitos do consumidor a informação adequada e clara sobre os diferentes produtos e serviços com especificação correta de quantidade, características, composição, qualidade e preço, bem como sobre os riscos que apresentem.

As contaminações químicas e biológicas durante a produção, processamento e consumo em decorrência das práticas inadequadas aumentam substancialmente o risco de ocorrência de DTAs (KÄFERSTEIN,1999). A migração não planejada das áreas rurais para as urbanas e o conseqüente crescimento da população nas cidades leva a formação de favelas que aumentam a poluição do ambiente e das águas. A falta de suprimento de água potável e rede de esgoto representam risco de disseminação de patógenos, particularmente em países em desenvolvimento (KÄFERSTEIN,1999). A probabilidade de contrair DTAs também aumentaram devido a mudanças globais que facilitaram o transporte dos alimentos perecíveis de locais distantes; a mudança no 
padrão de consumo e a falta de conhecimento dos consumidores a respeito de preparação segura dos alimentos. (SHEWMAKE, 1998).

As DTAs, de qualquer forma, ocorrem tanto em países desenvolvidos como em países em desenvolvimento (KÄFERSTEIN,1999). Nos Estados Unidos, são registrados cerca de 9 milhões de casos de doenças de origem alimentar com mais de 9 mil mortes a cada ano. Sabe-se que estes valores são subestimados, pois muitos não são notificados pela rotina de vigilância epidemiológica (MEAD, 1999; SHEWMAKE, 1998). O CDC (Centro de Controle e Prevenção de Doenças dos Estados Unidos, ou Center for Disease Control and Prevention) estima que 97\% de todos os casos de toxinfecção alimentar são causados por manipulação inadequada dos alimentos; 79\% são de alimentos preparados em estabelecimentos comerciais ou instituições e $21 \%$ por alimentos preparados nas residências. De acordo com a Organização Panamericana de Saúde, (OPAS, 2003), a ocorrência de surtos em domicílios é consistente em diversas regiões da América, destacando-se a América Central, com 50\% dos surtos ocorridos em ambientes domiciliares. As práticas mais comuns que levam à ocorrência destes surtos são a manutenção dos alimentos em temperaturas que propiciam o crescimento bacteriano, cozimento ou reaquecimento inadequados, contaminação cruzada e deficiência do estado de saúde e hábitos de higiene do manipulador (SHEWMAKE, 1998).

Mais de 200 doenças transmitidas pelos alimentos são conhecidas. As causas incluem vírus, bactérias, protozoários, fungos, parasitas, toxinas, metais e príons (MEAD, 1999). Nos Estados Unidos, dois terços dos surtos de DTAs são causados por bactérias. Segundo SHEWMAKE (1998), as mais comumente envolvidas nos surtos são a Salmonella, bacilo Gram negativo do tipo não tifóide; Staphylococcus aureus, associado a $25 \%$ dos surtos registrados e Clostridium perfringens, responsável por 
cerca de $17 \%$ dos casos. Alguns grupos de bactérias são considerados emergentes como causadoras de intoxicação alimentar como por exemplo Cryptosporidium, Cyclospora, Campylobacter jejuni, e Escherichia coli $\mathrm{O}$ 157:H7, entre outros.

As principais doenças transmitidas por alimentos de origem microbiana, possuem como características comuns um curto período de incubação e um quadro clínico gastrointestinal manifestado por diarréia, náuseas, vômitos e dor abdominal, acompanhado ou não por febre. Em geral há recuperação total do paciente. No entanto, indivíduos muito jovens, idosos ou debilitados podem apresentar complicações graves, muitas vezes levando à morte (UNGAR, 1992).

Há conseqüências econômicas das doenças de origem alimentar tanto para os indivíduos que contraem a doença, quanto para seus familiares, empregadores e para os órgãos oficiais de saúde. Na Inglaterra e no País de Gales em 1991, aproximadamente 23 mil casos de salmonelose tiveram custos estimados de 40 e 50 milhões de libras. $\mathrm{O}$ FDA (Food and Drug Administration) - agência federal americana que regulamenta os alimentos produzidos e comercializados no país, e atua na prevenção e investigação de DTAs, - tem um gasto de 5 até 17 bilhões de dólares devido às enfermidades causadas pela ingestão de alimentos contaminados (FORSYTHE, 2002).

A prevenção de DTAs nos Estados Unidos é baseada no programa de redução de patógenos, controle dos perigos no processamento dos alimentos, vigilância epidemiológica das doenças de origem alimentar e manipulação segura dos alimentos pelos consumidores e pelos trabalhadores da área de alimentos (ALTEKRUSSE, 1995).

É importante ressaltar que os manipuladores representam uma considerável fonte de disseminação de microrganismos seja através de seu próprio organismo, quando acometido por alguma enfermidade ou carreando naturalmente algumas 
bactérias na pele e mucosas, quanto pelos procedimentos inadequados que ele executa, como a manipulação e acondicionamento inadequados dos alimentos.

Para garantir a qualidade higiênico-sanitária dos alimentos tem sido utilizadas ferramentas como as boas práticas de fabricação e manipulação dos alimentos, chamadas de GMP (Good Manufacturing Practices) e o sistema de Análise de Perigos e Pontos Críticos de Controle (APPCC ou Hazards Analysis and Critical Control PointsHACCP). A implementação desses programas deve contar com o auxílio de programas de educação em saúde continuada para todos os envolvidos na cadeia de produção de alimentos, visando a capacitação e conscientização dos mesmos para a promocão da higiene, da saúde e da segurança alimentar(ZACCARELLI, 2000).

O monitoramento microbiológico dos manipuladores e das estruturas que com estes estabelecem contato representa importante instrumento para o controle da qualidade higiênica e sanitária dos alimentos em todas as fases de produção. Existem padrões, estabelecidos pelos órgãos oficiais competentes que devem ser seguidos pelos estabelecimentos (FRANCO, 1992).

As estratégias para reduzir as ocorrências de DTAs envolvem a implementação de programas educativos para consumidores e manipuladores capacitando-os a reconhecer as causas da contaminação dos alimentos, as formas de prevenção e principalmente a adotar as práticas que diminuem os riscos de contaminação (YANG, 1998). Práticas corretas de higiene, uniformização adequada, hábitos corretos durante a manipulação (não falar, não espirrar sobre os alimentos, lavar as mãos após ir ao banheiro, entre outros), cuidados para evitar contaminações cruzadas e multiplicação bacteriana exagerada e manutenção dos alimentos em temperatura adequada são 
exemplos do que pode ser feito para reduzir substancialmente o risco de contaminação dos alimentos.

A educação em saúde constitui um dos caminhos pelos quais a promoção da saúde se torna viável. Por promoção de saúde no âmbito da alimentação, entende-se o conjunto de ações dos setores público e privado, de indivíduos e grupos, que tenham por finalidade garantir a segurança dos alimentos (GERMANO, 2002). A educação em saúde deve buscar desenvolver a autonomia dos indivíduos, já que permite desenvolver habilidades pessoais, estimular o diálogo entre saberes, fornecer os elementos para a análise crítica e o reconhecimento dos fatores determinantes sobre seu estado de saúde além de decidir sobre as ações mais apropriadas para promover a própria saúde e a de sua comunidade, entre outros fatores (GERMANO, 2002). Segundo RECKS, (1994), o pensamento crítico é necessário para a sobrevivência nesse mundo com tão rápidas modificações.

Para implementar qualquer projeto ou programa educativo para manipuladores e consumidores é importante conhecer o público-alvo. Antes que a educação da população e programas de treinamento sejam planejados e materiais didáticos sejam produzidos, é necessário que os profissionais da área identifiquem o que os consumidores sabem a respeito da segurança alimentar e das práticas de preparação em casa (ANGELILLO, 2001; MANNING, 1994; WILLIAMSON, 1992). A manipulação dos alimentos e os hábitos de consumo são influenciados por crenças e hábitos (FEIN, 1995). A educação em saúde tem que se adequar ao meio e aos problemas a ele relacionados, de modo que os conhecimentos de saúde sejam colocados em prática, caso contrário o resultado da educação em saúde não é satisfatório (SANTOS, 2003).

Nesse contexto de educação em saúde, percebe-se a necessidade da participação de profissionais de diversas áreas, caracterizando equipes multidisciplinares. Para Pezza 
(in SANTOS, 2003), o médico veterinário é um agente de educação em saúde, já que sua atividade contribui para a proteção da saúde do homem, seja através do controle de zoonoses, ou pelo controle higiênico-sanitário dos alimentos de origem animal.

A participação da comunidade vem sendo introduzida nos projetos educativos atuais e está contemplada como uma das estratégias para a solução de problemas relacionados com a proteção dos alimentos e a prevenção das doenças transmitidas por estes. Um exemplo são os Programas Regionais de Cooperação Técnica em Proteção de Alimentos da OPAS/OMS executada pelo Instituto Panamericano de Proteção dos Alimentos e Zoonoses (INPPAZ), cujo mote é a mobilização da comunidade para motivar sua participação como agente de mudança (OPAS/OMS, 2001). Países como o Peru, Chile, México e Colômbia desenvolveram ações educativas nesse campo com a cooperação da OPAS/OMS e outras organizações como a FAO, e nas quais foram utilizados meios de comunicação, em especial televisão e rádio. Apesar da ampla cobertura, faltaram atividades de avaliação que permitiriam conhecer uma resposta do receptor a respeito das mudanças de atitude (OPAS/OMS, 2001). Isso confirma a importância da avaliação, tanto no início de um projeto educativo como no final, a fim de conhecer as estratégias bem sucedidas que tiveram resultado satisfatório e aquilo que deve ser modificado.

Para que a educação seja efetiva, o homem deve ser visto interagindo com a realidade que ele sente, percebe e sobre a qual exerce uma prática transformadora. A educação deve ser um processo de constante libertação do homem. O educador, num processo de conscientização, tem o direito a opções, o que não tem é o direito de impôlas. A educação como prática da liberdade não é uma transferência ou transmissão de saber, não é a extensão de conhecimentos técnicos, não é o ato de depositar informes ou fatos nos educandos, não é o esforço de adaptação do educando a seu meio. Educador e 
educando são ambos sujeitos cognoscentes, diante de objetos cognoscíveis que os mediatizam. Em outras palavras, educador e educando estão ambos aprendendo sobre o assunto em questão, uma vez que todos possuem algum conhecimento, o que é diferente é o ponto de vista (FREIRE, 1977; REICKS, 1994). Por esta razão torna-se imprescindível conhecer o sujeito (cognoscente) e sua relação com o assunto (objeto congoscível) antes de dar início a um projeto de controle de DTAs em uma comunidade. Assim, será possível definir os propósitos do projeto e os mecanismos de avaliação do mesmo.

Este conceito de educação até então citado não chega a ser algo novo, mas pouco utilizado principalmente nos programas e projetos de educação em saúde. O que se fazia era exatamente o contrário: a imposição do saber por parte do educador sem levar em conta os conhecimentos, os hábitos, enfim, a cultura do educando. Uma grande parte das práticas de educação popular nos serviços de saúde estão hoje voltadas para a superação do fosso cultural existente entre a instituição e a população, em que um lado não compreende a lógica e as atitudes do outro. Nessas experiências, isso é feito com base em uma perspectiva de compromisso com os interesses políticos das classes populares, mas reconhecendo, cada vez mais sua diversidade e heterogeneidade. Estas práticas começam atuando em problemas de saúde específicos e utilizam metodologias que buscam entender, sistematizar e difundir as lógicas, os conhecimentos e os princípios que regem a subjetividade dos vários atores envolvidos no processo educador-educando de forma a superar as incompreensões e malentendidos (VASCONCELOS, 2001).

O passo inicial para conhecer a população e assim conseguir desenvolver um projeto educativo nos moldes descritos, ou seja, com profundo respeito ao educando e visando também o aprendizado durante o processo, é fazer contato com os interessados 
tentando identificar suas expectativas, os problemas da situação, as características da população e outros aspectos que permitem elaborar o chamado "diagnóstico". No contexto do serviço social, o diagnóstico é visto como "processo" e como "produto". De acordo com a primeira acepção, trata-se de um "processo de identificação dos problemas de uma situação e decisão de meios adequados para encontrar soluções". Na segunda, o diagnóstico é constituído pelas informações a partir das quais são estabelecidas metas de ação (THIOLLENT,1994).

As entrevistas são ferramentas de extrema utilidade dentro de um projeto educativo. Estes métodos de levantamento de informações são utilizados na etapa denominada de "diagnóstico educativo" cujos propósitos básicos são definir com exatidão os limites do programa educativo e medir as mudanças, através das informações que são obtidas e referem-se ao problema a ser abordado, seus fatores determinantes e condicionantes e sua dimensão (SECRETARIA DA EDUCAÇÃO DO ESTADO DO CEARÁ, 1983). Apesar de serem largamente utilizadas, tanto nas áreas humanas e sociais quanto nas ciências naturais, as entrevistas freqüentemente recebem críticas enquanto método de coleta de dados. As principais críticas dizem respeito à influência que o entrevistado recebe do entrevistador, possibilitando alterações nas suas respostas e na incompreensão por parte do entrevistado do objetivo das questões formuladas (OLIVAL, 2002). Não há como reverter esses efeitos, mas as entrevistas possuem diversas vantagens que fazem com que seja o meio mais apropriado para um diagnóstico inicial: $\mathrm{O}$ entrevistado não precisa ser alfabetizado, o entrevistador pode explicar as perguntas que não ficaram claras e ver as circunstâncias em que as informações foram dadas (FEUERSTEIN, 1990). Além disso, a realização de pré-testes para ajustes e adequações são indispensáveis e contribuem na redução dessas falhas. 
O formulário para as entrevistas pode ter questões abertas, fechadas ou mistas. Nas questões fechadas existem alternativas às respostas. Nas questões abertas não há qualquer tendência de resposta, o entrevistado pode responder com suas próprias palavras e há possibilidade do desenvolvimento de questões fechadas em uma etapa posterior, na elaboração de um questionário mais específico. Alguns pontos como a dificuldade na interpretação e análise das respostas e produção de muitas variáveis podem transformar as questões abertas em uma opção mais trabalhosa (OLIVAL, 2003).

Elaborado o instrumento de pesquisa, parte-se para a escolha do público-alvo, que podem ser freqüentadores ou moradores de um mesmo local, usuários de um mesmo serviço ou consumidores de um mesmo produto. Enfim, devem ter algo em comum. Esta é a definição de comunidade: um agrupamento de pessoas em torno de um objetivo comum, a ser alcançado por todos. Uma comunidade pode ser definida por limites geográficos contendo uma população definida por residências, ruas, estrutura comercial, hábitos e práticas que a caracterizam. Esse conceito explica a escolha de uma comunidade específica para a realização deste trabalho. Além do objetivo comum, que pode ser simplesmente morar, outras condições favoreceram essa escolha, pois trata-se de uma comunidade carente, ou favela, com uma ausência de infra-estrutura sanitária que leva seus moradores a lançarem seus dejetos ao ar livre ou diretamente a córregos ou represas. Por comunidade carente ou favela, entende-se:

“Um aglomerado de moradias de reduzidas dimensões, construídas com resíduo industrial ( madeira velha, zinco, lata) e, distribuídas irregularmente em terrenos quase sempre desprovidos de serviços urbanos e de equipamentos sociais, compondo um complexo de problemas de ordem social, econômica, sanitária, educacional e urbanística. Localiza-se quase sempre em terrenos baldios públicos ou de propriedade particular, próximos a zonas que possam oferecer ao favelado algum tipo de sobrevivência" (in TANAKA, 1993). 
A favela surge como expressão física das contradições urbanas de uma sociedade pobre e concentradora da pouca riqueza que tem. Embora a precariedade seja evidente, houve melhoria nas condições de vida do contingente favelado nos anos 90, que agora tem acesso à energia elétrica domiciliar, água corrente e coleta de lixo.Tratase de um aglomerado de trabalhadores pobres que optaram pela favela como estratégia possível de sobrevivência (TASCHNER, 1997). A possibilidade de ocorrência de doenças transmitidas por alimentos e água nessas localidades é grande devido a esses problemas de edificação e saneamento. A educação em saúde visando a segurança alimentar procura minimizar esses fatores tornando a população consciente de como prevenir os agravos que essas condições podem trazer e apta a mudar seu comportamento adotando práticas mais adequadas com os alimentos. 


\section{MATERIAL E MÉTODOS}

\subsection{MODALIDADE DE PESQUISA}

O trabalho foi dividido em duas partes, sendo a primeira o estudo descritivo da população e dos comerciantes da Comunidade São Remo no que se refere a conhecimentos e práticas de higiene com os alimentos. Esses dados foram obtidos a partir de entrevistas. Os instrumentos de pesquisa (questionários para a comunidade e para os comerciantes) foram submetidos a teste prévio. As entrevistas com os comerciantes foram feitas no mês de Maio de 2001 e com a população, no período de Agosto a Novembro do mesmo ano.

A segunda parte consistiu em analisar alimentos comercializados na comunidade a fim de caracterizar alguns perigos biológicos oferecidos pelos alimentos. Foram pesquisados alguns microrganismos patogênicos e indicadores da qualidade higiênico sanitária dos alimentos. As amostras foram processadas no Laboratório de Higiene Alimentar do Departamento de Medicina Veterinária Preventiva e Saúde Animal da Faculdade de Medicina Veterinária e Zootecnia da USP no período de Outubro a Novembro de 2001. 


\subsection{LOCALIZAÇÃO DA COMUNIDADE SÃO REMO}

A Comunidade São Remo localiza-se na zona Oeste do Município de São Paulo. Tem como limites a Cidade Universitária, o $16^{\circ}$ Batalhão da Polícia Militar e a Avenida

Corifeu de Azevedo Marques (Figura 1). Dados do Instituto Brasileiro de Geografia e Estatística, IBGE, censo de 2000, revelam a existência de cerca de 1576 domicílios com 6.304 moradores.

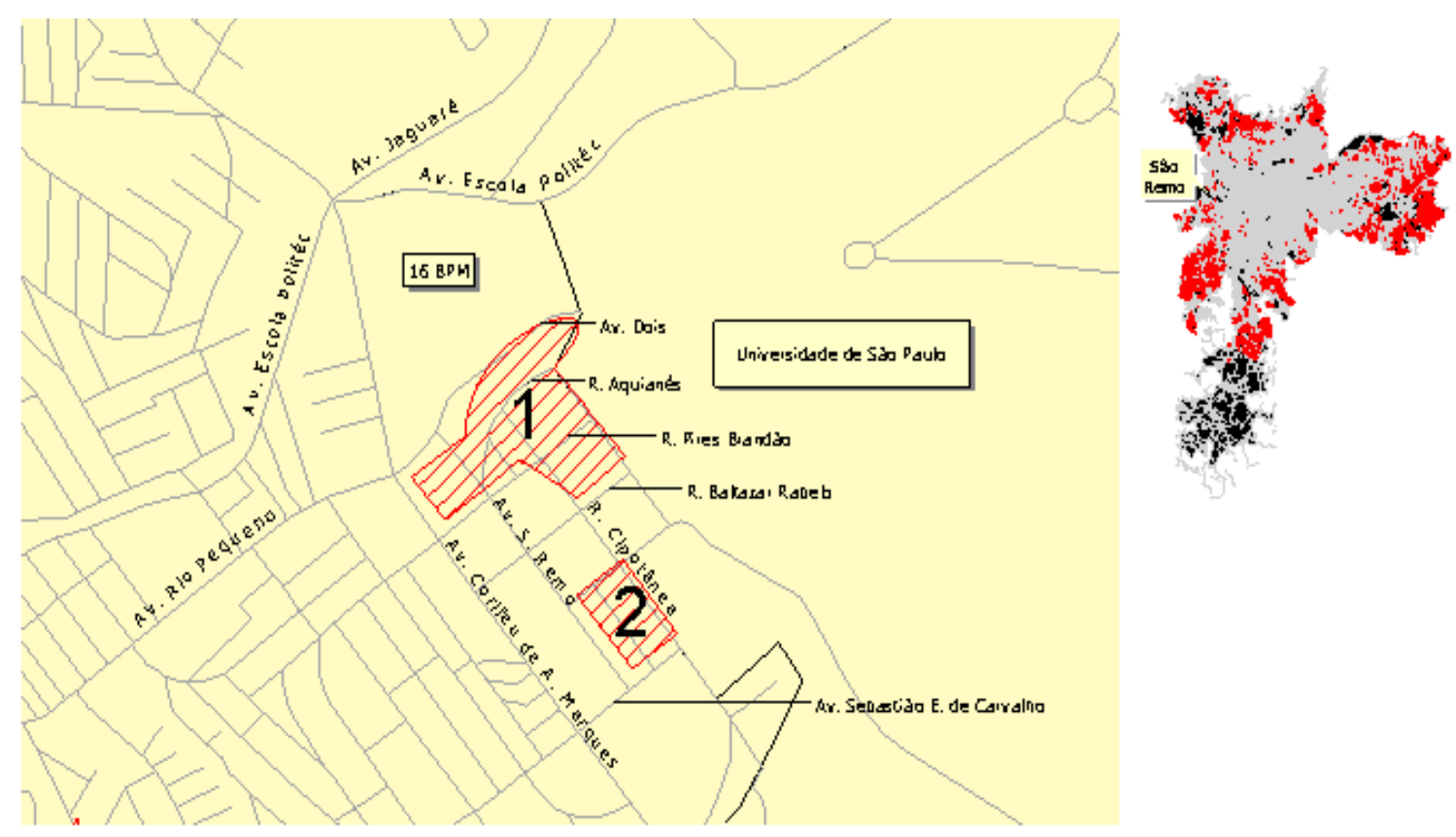

Figura 1- Delimitações da Comunidade São Remo e localização no Município. São Paulo, 2002

\subsection{ESTUDO DESCRITIVO}

Amostra 
A amostra da população estudada foi definida tomando como base uma freqüência de ocorrência dos eventos referentes aos conhecimentos sobre higiene e microbiologia dos alimentos de 50\%. Foi atribuído um nível de confiança de $95 \%$ e precisão de 5\%. Utilizou-se o programa Epinfo 2000, no qual os valores referentes a tamanho da população, freqüência de ocorrência do evento, nível de confiança e precisão eram fornecidos e obtinha-se o tamanho da amostra. O número encontrado foi de 309 domicílios. O processo de entrevistas nos domicílios teve início em uma rua aleatória da comunidade, escolhendo-se a primeira residência também dessa forma. A partir daí, a cada cinco domicílios, um era entrevistado.

Durante a realização da pesquisa identificou-se o número de pontos de vendas de alimentos na comunidade, chegando a um total de 100 estabelecimentos. A amostra dos estabelecimentos foi definida por conveniência. Durante a pesquisa, 66 concederam entrevista válida para o trabalho, correspondendo a $66 \%$ dos pontos de venda de alimentos. Os demais encontravam-se fechados ou não autorizaram a pesquisa. A maioria dos estabelecimentos está localizada nas ruas principais da favela. Em algumas dessas ruas a presença de comércio é predominante em relação a domicílios.

Instrumento de pesquisa

Foram utilizados dois questionários, ambos semi-estruturados. Um questionário para a população contendo 32 questões e um para os comerciantes com 26 questões. Utilizou-se questões fechadas ou semi-fechadas a fim de identificar o grau de conhecimento a respeito de: a) microbiologia de alimentos; b) riscos que o alimento pode oferecer à saúde do consumidor e c) boas práticas de manipulação de alimentos. Foram empregadas questões abertas para que os entrevistados pudessem expressar 
opiniões a respeito dos problemas enfrentados enquanto comerciante ou habitante da comunidade.

As entrevistas foram feitas pela pesquisadora responsável e por auxiliares de pesquisa, recrutados e treinados para a atividade. Utilizaram-se fins de semana e alguns dias da semana para procedê-las.

Recrutamento e treinamento dos auxiliares de pesquisa

Foram recrutados alunos de graduação do curso de Medicina Veterinária e Zootecnia da Universidade de São Paulo (FMVZ-USP) a partir de convite por escrito para todas as turmas, do primeiro a quinto ano. Foram esclarecidos os objetivos da pesquisa e a metodologia de trabalho. Os interessados assinavam uma lista e previamente à realização dos trabalhos fazia-se uma reunião de orientação. Para as entrevistas nos estabelecimentos, contou-se com o auxílio de onze graduandos do segundo ao quinto ano e para as entrevistas da população contou-se com 15 (quinze) auxiliares que compareceram alternadamente.

As reuniões prévias às entrevistas abordavam: objetivos da pesquisa; características da comunidade; comportamento como pesquisador; ética para com o entrevistado; como proceder a entrevista (apresentar-se, apresentar a pesquisa e pedir permissão verbal para realizá-la); leitura do questionário e discussão e esclarecimento de dúvidas. Os pesquisadores foram esclarecidos de que deveriam escrever o questionário com letra legível, tomando o cuidado de não influenciar a resposta do entrevistado e de transcrever, sem interpretar, as palavras do entrevistado. 
Pré-teste do instrumento de pesquisa

O pré-teste foi realizado na própria comunidade. Foram entrevistados 15 proprietários de estabelecimentos comerciantes de alimentos e 20 moradores de diferentes áreas da Comunidade. $\mathrm{O}$ pré-teste foi realizado pela pesquisadora responsável e pelos auxiliares. Após a aplicação foram discutidos diversos aspectos do questionário, como a clareza e objetividade das questões e impressões a respeito dos entrevistados. Com isso, algumas questões foram modificadas, obtendo-se o questionário definitivo.

Questionários

Para cada um dos públicos-alvo do estudo (comerciantes de alimentos e moradores da comunidade), elaborou-se um questionário que encontram-se nos anexos A e B.

Questionário para os comerciantes de alimentos

Abordaram-se os seguintes aspectos:

1. Características do comerciante: Nome, sexo, idade, experiência anterior na área de alimentos, tempo que possui o atual comércio, se esta é sua única fonte de renda;

2. Aquisição das Matérias-primas: Quais os aspectos considerados na aquisição das matérias primas e no recebimento do produto; 
3. Microrganismos: O que são, onde são encontrados;

4. Definição de falta de higiene e suas implicações;

5. Procedimentos de higiene para com os alimentos e no estabelecimento (freqüência de limpeza, produtos utilizados), e higiene pessoal;

6. Doenças transmitidas pelos alimentos;

7. Questões relativas à comunidade: Quais as dificuldades enfrentadas enquanto comerciante, quais os problemas mais relevantes da comunidade, quais tem sido as soluções para tais problemas;

8. Receptividade a projetos educativos;

9. Conhecimento sobre legislação no setor de alimentos, análise microbiológica de alimentos, etc.

Questionário para os moradores da comunidade

1. Características dos moradores e do domicílio; Nome, sexo, idade, escolaridade, profissão, número de pessoas residentes no domicílio e alimentos preparados com maior freqüência;

2. Aquisição dos alimentos: Características observadas no produto, freqüência de compra, condições do armazenamento;

3. Microrganismos: O que são, onde são encontrados;

4. Definição de falta de higiene e suas implicações;

5. Procedimentos de higiene para com os alimentos e higiene pessoal;

6. Doenças transmitidas pelos alimentos (DTAs);

7. Envolvimento em ocorrência de DTAs (alimento envolvido, sintomas apresentados, providências tomadas); 
8. Dificuldades relativas à comunidade: possíveis soluções;

9. Receptividade a projetos educativos;

Aplicação do teste

As idas ao local eram sempre feitas em grupos que se dividiam dentro da comunidade, ficando todos com um celular e os números de telefone do restante da equipe. Ao final das entrevistas, todos se encontravam em um local previamente combinado e retornavam juntos. Fazia-se uma discussão sobre as dificuldades e peculiaridades enfrentadas durante a execução das entrevistas e os questionários eram entregues ao coordenador. Havia também, no próprio questionário, um espaço para que o pesquisador escrevesse suas impressões a respeito do entrevistado ou do questionário.

Processamento e análise dos dados

As respostas das questões semi-estruturadas e abertas foram agrupadas em categorias de acordo com a semelhança identificada entre elas. Comentários relevantes emitidos pelos entrevistados foram transcritos.

Os dados foram organizados e armazenados em um banco de dados do programa Microsoft Access ${ }^{\circledR}$. Em seguida foram processados no programa SPSS 9.0 for Windows (SPSS, 1999) para obtenção da freqüência de aparecimento das respostas. 


\subsection{ANÁLISE DOS ALIMENTOS}

Amostra

Escolheu-se analisar os alimentos para a pesquisa de indicadores da qualidade higiênica (coliformes totais, bolores e leveduras), da qualidade higiênico-sanitária (coliformes fecais e Staphylococcus coagulase positiva) e pesquisa de patogênicos (Salmonella spp). Analisou-se 40 amostras de alimentos, sendo 20 de alimentos in natura e 20 de alimentos prontos para o consumo.

Análises microbiológicas

Para os alimentos in natura, as análises realizadas foram enumeração de coliformes totais e coliformes fecais e pesquisa de Salmonella spp. Para os alimentos prontos para o consumo, realizou-se enumeração de Coliformes totais e fecais e pesquisa de Staphylococcus coagulase positiva. Dentre os produtos escolhidos constavam carne bovina (em pedaço, bife ou moída), frango temperado e frango fresco, carne seca, peixe congelado e lingüiça (embutida e frescal), como produtos in natura e pastéis (sabores carne, bauru e frango), salgados fritos (coxinha de frango, risoles de queijo, de presunto e de frango), esfiha, cachorros quentes, refeições e queijo tipo requeijão do norte como alimentos prontos para o consumo (Tabela 1). As análises escolhidas para cada tipo de alimento levaram em conta as características intrínsecas ( $\mathrm{pH}$, atividade de água, potencial redox, conteúdo em nutrientes e estrutura biológica) e 
extrínsecas do mesmo (temperatura de manutenção, umidade, presença e concentração de gases) que os deixam mais suscetíveis à contaminação por um ou outro tipo de microrganismo (GERMANO, 2001). A metodologia utilizada baseou-se em "Métodos de análise microbiológica para alimentos” (1992), do Ministério da Agricultura do Abastecimento e da Reforma Agrária.

Tabela 1- Alimentos colhidos para análise microbiológica separados por tipo e por tipo de análise realizada, São Paulo, 2001

\begin{tabular}{|c|c|c|c|c|c|c|}
\hline & \multirow[t]{2}{*}{ Tipo de alimento } & \multirow{2}{*}{$\begin{array}{l}\text { Quanti- } \\
\text { dade }\end{array}$} & \multicolumn{4}{|c|}{ Análises realizadas } \\
\hline & & & Col. & Sal. & Sta. & B/L \\
\hline \multirow{5}{*}{$\begin{array}{l}\text { Alimento in } \\
\text { natura }\end{array}$} & Carne seca & 5 & $\mathrm{X}$ & $\bar{X}$ & $\bar{X}$ & $\bar{X}$ \\
\hline & Lingüiça paio/ fresca & 4 & $\mathrm{X}$ & $\mathrm{X}$ & & \\
\hline & $\begin{array}{l}\text { Frango fresco/ frango } \\
\text { temperado }\end{array}$ & 4 & $X$ & $X$ & & \\
\hline & Peixe congelado & 2 & $\mathrm{X}$ & $\mathrm{X}$ & & \\
\hline & $\begin{array}{l}\text { Carne bovina inteira/ } \\
\text { moída }\end{array}$ & 5 & $\mathrm{X}$ & $\mathrm{X}$ & & \\
\hline \multirow{5}{*}{$\begin{array}{c}\text { Alimento } \\
\text { pronto } \\
\text { para o } \\
\text { consumo }\end{array}$} & $\begin{array}{l}\text { Pastel (carne, bauru e } \\
\text { frango) }\end{array}$ & 5 & $\mathrm{X}$ & $\mathrm{X}$ & $X$ & \\
\hline & $\begin{array}{l}\text { Salgados (coxinha, } \\
\text { esfiha) }\end{array}$ & 5 & $\mathrm{X}$ & $\mathrm{X}$ & $\mathrm{X}$ & \\
\hline & Cachorro quente & 2 & $X$ & $X$ & $X$ & \\
\hline & Requeijão do Norte & 5 & $X$ & & $\mathrm{X}$ & \\
\hline & Refeição & 3 & $X$ & $\mathrm{X}$ & $\mathrm{X}$ & \\
\hline Total & & 40 & 40 & 35 & 25 & 5 \\
\hline
\end{tabular}

Colheita e processamento das amostras

Foram obtidas 40 amostras de alimentos, de 16 tipos diferentes de produtos, entre Outubro e Novembro de 2001. As amostras eram acondicionadas em saco plástico estéril, mantendo-se a embalagem original, quando presente. As amostras eram identificadas e acondicionadas em caixa isotérmica, com gelox ${ }^{\circledR}$ sendo encaminhadas ao laboratório de Higiene Alimentar do Departamento de Medicina Veterinária Preventiva e Saúde Animal-VPS em um período máximo de três horas. Os alimentos 
prontos para o consumo eram os primeiros a serem submetidos às análises, enquanto que aqueles "in natura" e congelados eram mantidos em geladeira (entre $4^{\circ}$ a $10^{\circ}$ ) e processados 24 horas depois. Os resultados das análises foram comparados aos valores padrão estabelecidos pela legislação em vigor ,RDC n॰ 12 de Janeiro de 2001 (BRASIL, 2001).

Entrega dos resultados das análises

Os resultados das análises laboratoriais foram entregues aos comerciantes juntamente com um folheto educativo contendo informações a respeito de microbiologia dos alimentos (ANEXO C). Com alguns dos comerciantes foi possível discutir os resultados obtidos nas análises e o conteúdo do folheto de orientação sobre higiene dos alimentos. Salientou-se que a ausência do microrganismo pesquisado não significa que o produto esteja isento de outros microrganismos, formas de resistência, toxinas ou de resíduos de substâncias tóxicas. 


\section{RESULTADOS E DISCUSSÃO}

\subsection{ENTREVISTA COM OS COMERCIANTES DE ALIMENTOS DA COMUNIDADE SÃO REMO}

Caracterização dos entrevistados

Do total de entrevistados, $42(63,6 \%)$ eram do sexo masculino e $24(36,4 \%)$ eram do sexo feminino. O gráfico 1 caracteriza os comerciantes de acordo com a faixa etária, sendo predominante as pessoas entre 30 e 50 anos de idade (56,1\%). A predominância do sexo masculino na atividade e a presença de pessoas com idade acima de 30 anos, revela ser esta uma atividade alternativa para as pessoas que não conseguem uma colocação no mercado de trabalho. Esta suposição se apóia também no fato de que para 35 (53\%) comerciantes, essa é a única ou a principal fonte de renda da família (questão $\mathrm{n}^{\mathrm{o}}$ 3).

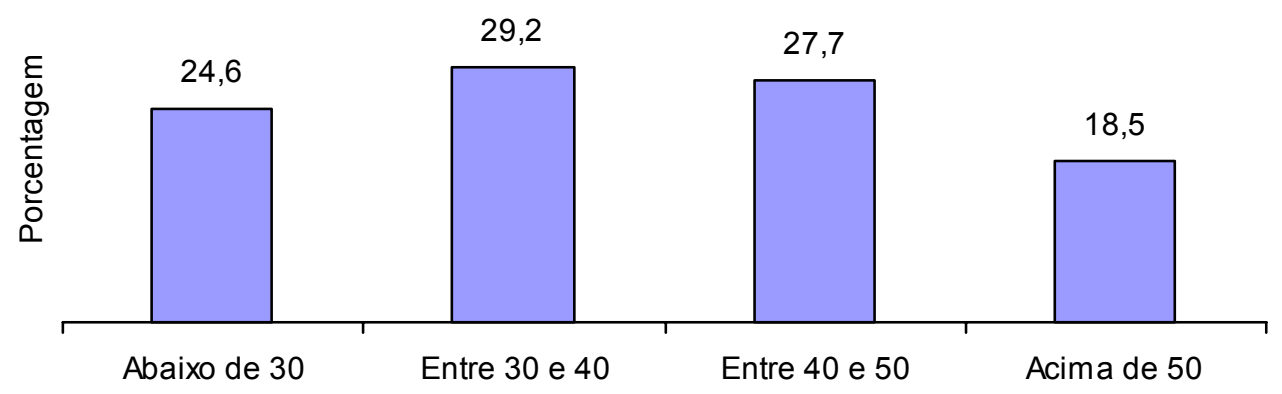


Gráfico 1- Idade dos entrevistados, homens e mulheres, proprietários de estabelecimentos que comercializam alimentos na comunidade São Remo, São Paulo, 2001.

O gráfico 2 apresenta o nível de escolaridade dos entrevistados. Há uma concentração de pessoas que cursaram o ensino fundamental: 48 (73,8\%), tendo ou não concluído esta etapa. Esta constatação é de grande importância no auxílio da escolha do meio de comunicação-educação a ser adotado em um projeto de treinamento dos comerciantes. Isso porque o veículo utilizado deve ser adequado ao público, ou seja, para pessoas que não tem muita intimidade com a leitura ou não sabem ler, devem ser exploradas formas de contato direto, como reuniões ou palestras, ou meios onde a escrita não seja fundamental, como rádio, teatro e televisão. Deve-se sempre considerar o educando como parte ativa do processo de educação, onde ele não apenas "recebe" aquilo que será "passado" pelo educador, mas opina e modifica a informação de modo a aplicá-la em sua realidade:

“Enquanto na prática 'bancária’da educação, antidialógica por essência, por isto, não comunicativa , o educador deposita no educando o conteúdo programático da educação, que ele mesmo elabora ou elaboram para ele, na prática problematizadora, dialógica por excelência, este conteúdo, que jamais é 'depositado', se organiza e se constitui na visão de mundo dos educandos, em que se encontram seus temas geradores" (FREIRE, 2001).

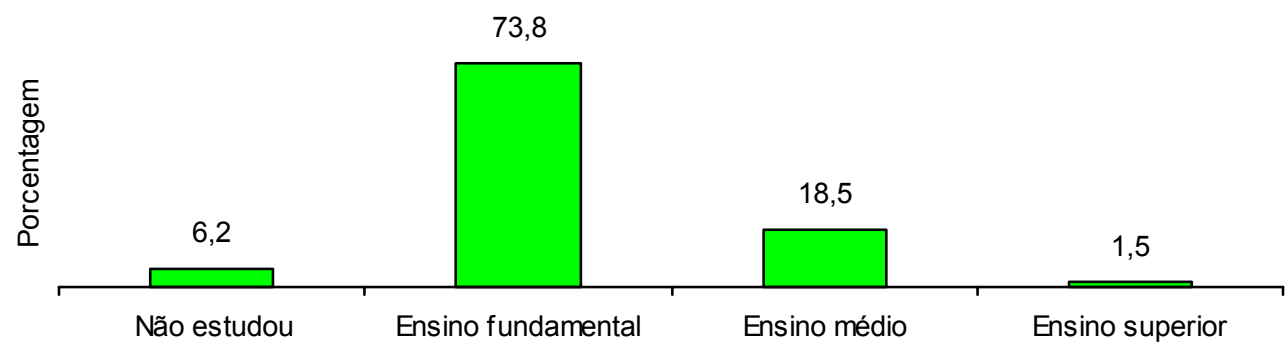

Gráfico 2- Nível de escolaridade dos entrevistados, homens e mulheres, nos estabelecimentos de alimentos da comunidade São Remo, São Paulo, 2001. 
A questão 1 refere-se ao tempo de funcionamento dos estabelecimentos, sendo que $43(65,1 \%)$ estão presentes entre um e cinco anos, $10(15,2 \%)$ existem há mais de cinco anos e $13(19,7 \%)$ existem há mais de dez anos. O grande número de estabelecimentos novos parece refletir a situação social-econômica de dificuldades pela qual o País está passando. O comércio de gêneros alimentícios surge como uma alternativa "possível”, em virtude da aparente facilidade de aquisição, preparo e comercialização destes produtos. Isso também ocorre com o comércio de rua, que aumenta em épocas econômicas desfavoráveis.

"As dificuldades econômicas encontradas nos países de terceiro mundo levaram a uma deterioração das condições sócio-econômicas das populações de baixa renda e das áreas rurais, o que provocou uma onda crescente de migração para os centros urbanos. Quando estes migrantes alcançam as cidades, as poucas oportunidades de trabalho e a falta de treinamento fazem-nos sair à busca de formas alternativas de ganhar a vida, sendo uma delas o trabalho no mercado informal, incluindo o trabalho ambulante. Esta atividade representa um fenômeno sócio-econômico que emprega um grande número de pessoas, ajudando a reduzir os níveis de pobreza e marginalização. Apesar desses reconhecidos benefícios, a prática representa risco à população, já que na maioria dos casos os alimentos são preparados em condições precárias de higiene e por pessoas sem treinamento adequado para manipular alimentos" (WHO, 1996).

A indústria da comida de rua emprega 6 a $25 \%$ da força de trabalho em diversos países em desenvolvimento (ABDUSSALAM ; KÄFERSETEIN, 1993). De acordo com estudos do Instituto de Pesquisas Econômicas Aplicadas-IPEA, órgão vinculado ao ministério do planejamento, de Setembro de 1994 a Setembro de 1995, $17 \%$ do pessoal empregado passou da economia formal para o mercado informal, aumentando assim, o desamparo social, o trabalho precário sem mecanismos regulatórios por parte do estado e a instabilidade (IBANHES, 1999). A esse contexto social, não podemos deixar de somar a idade dos comerciantes e seu baixo nível de 
escolaridade, o que dificulta ainda mais a possibilidade de obter uma colocação no mercado formal.

Na questão 2, quando perguntados a respeito da experiência que possuíam na área de alimentos, constatou-se que menos de $50 \%$ dos entrevistados (31) tinham experiência. O gráfico 3 apresenta os diferentes segmentos na área de alimentos nos quais os comerciantes com experiências prévias desenvolveram alguma atividade. As freqüências observadas indicam que a comercialização de alimentos é uma alternativa viável na situação de desemprego, porém traz também um risco associado, uma vez que muitas destas pessoas não têm conhecimentos mínimos relativos à manipulação higiênica dos alimentos, ignorando que os alimentos podem servir como via de transmissão de doenças.

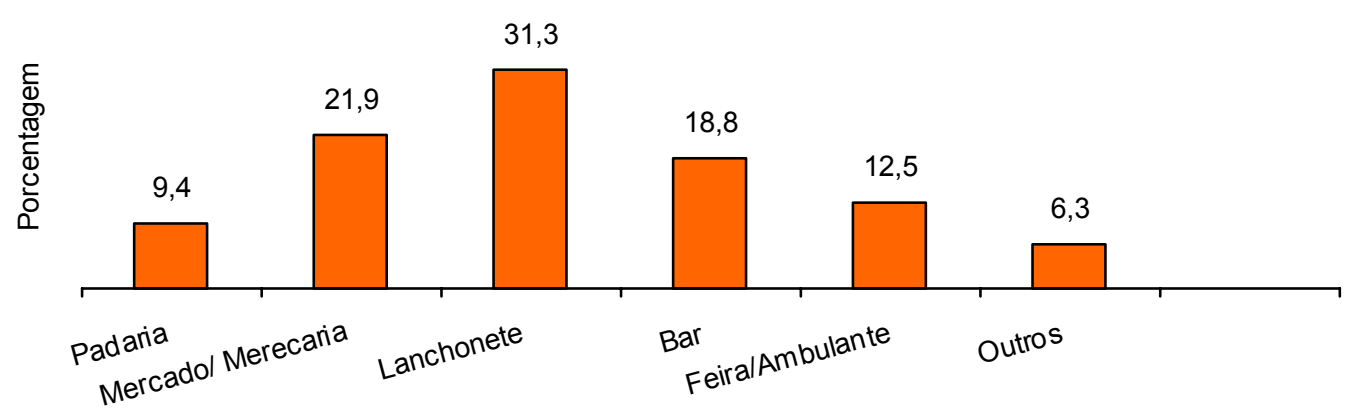

Gráfico 3- Experiências anteriores: Estabelecimentos de alimentos onde os proprietários já trabalharam. São Paulo, 2001.

A questão 8 procurou determinar se os comerciantes de alimentos da Comunidade São Remo já receberam algum tipo de treinamento para exercer esta atividade. Onze entrevistados $(16,7 \%)$ responderam afirmativamente. Com relação ao local, seis pessoas relataram ter recebido o treinamento no emprego anterior. Foi citada uma entidade que oferece treinamentos e capacitação (SENAI), onde o entrevistado fez 
um curso para produção de sorvete, além da Faculdade de Veterinária da USP (FMVZ), na qual um entrevistado recebeu treinamento dos alunos de graduação em medicina veterinária através EJAV (Empresa Júnior de Assistência Veterinária).

Caracterização dos Estabelecimentos:

Os estabelecimentos varejistas que comercializam alimentos estão classificados em diversas categorias, de acordo com a Portaria CVS 16/2003 (BRASIL, 2003). No entanto, cada proprietário definiu o tipo de estabelecimento que pertencia (gráfico 4), o qual também informou o(s) tipo(s) de produto(s) comercializado(s). Não houve grande discrepância entre a informação dada pelo comerciante e as categorias constantes na portaria nas quais os estabelecimentos se encaixam como: restaurante, açougue, padaria, supermercado, mercearia, quitanda e lanchonetes (onde ficam incluídos os bares, botecos e "Casas do Norte").

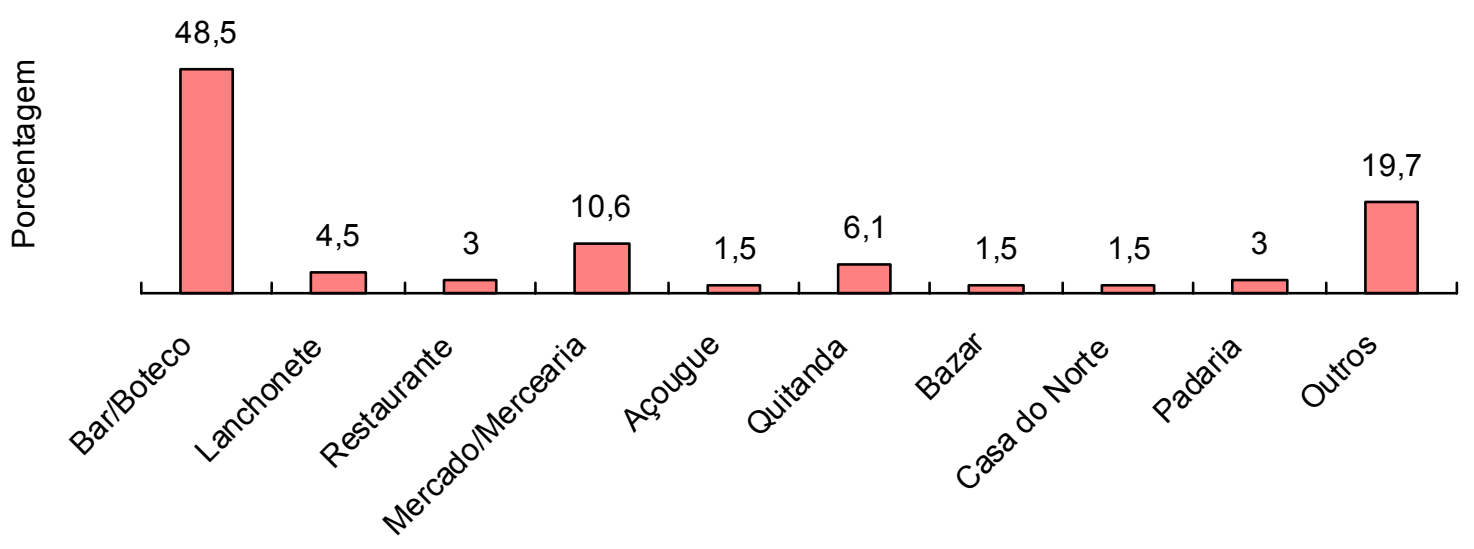

Gráfico 4- Estabelecimentos que comercializam alimentos existentes na Comunidade São Remo, separados por tipo. São Paulo, 2001.

Quanto aos produtos comercializados que foram questionados na pergunta 5, obteve-se: bebidas (51), pastel (9), leite e derivados (21), doces (32), produtos 
industrializados (enlatados, salgadinhos, bolachas) (41) refeições (8), porções (12), frutas (6) e produtos cárneos (20). Os valores em porcentagem encontram-se no gráfico 5. Em alguns estabelecimentos constatou-se a comercialização dos alimentos junto a outros produtos, em especial produtos de limpeza em mercadinhos e em um açougue e produtos de papelaria em uma mercearia. De acordo com a legislação citada, apenas os mercados e mercearias podem comercializar outros produtos que não alimentos, pois são definidos como comércio varejista de produtos predominantemente alimentícios.

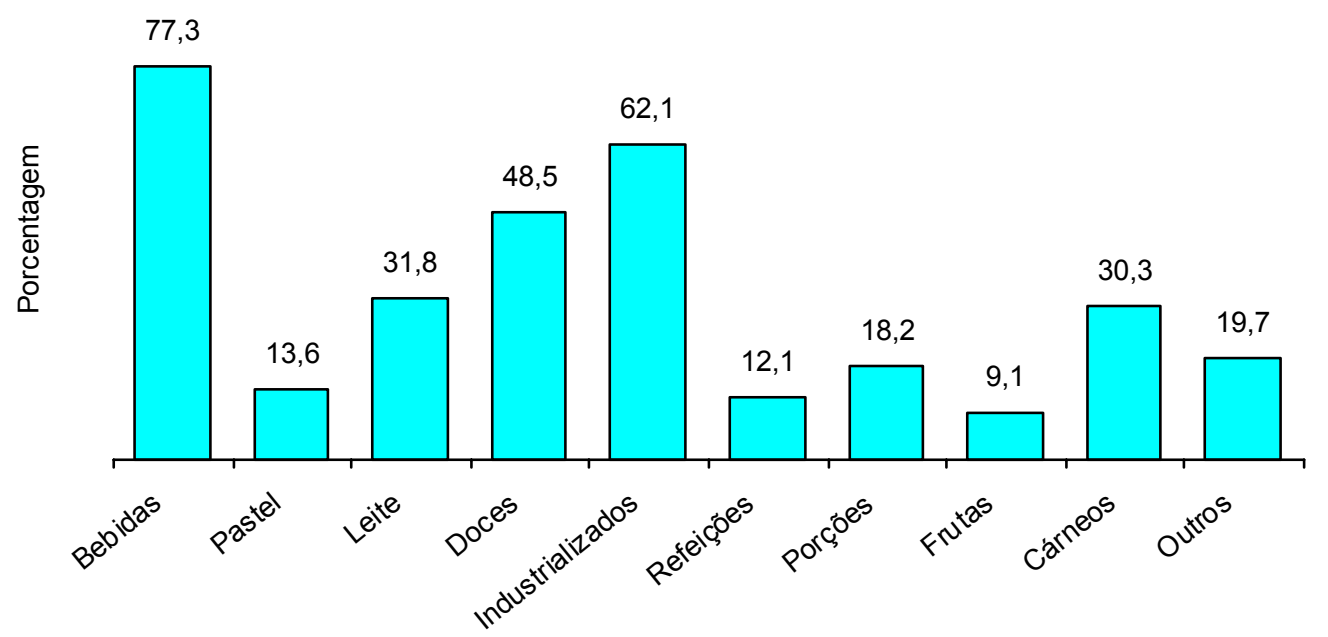

Gráfico 5- Tipos de alimentos comercializados nos estabelecimentos da Comunidade São Remo, São Paulo, 2001.

O número de estabelecimentos que realizam alguma etapa de manipulação do alimento, tais como descascar, rechear, fritar, cortar, porcionar, cozinhar, assar, dessalgar, entre outras é de cerca de $74,2 \%$ do total. Os estabelecimentos que realizam etapas de manipulação do alimento merecem que sejam discutidos em projetos educativos, questões referentes às boas práticas de aquisição, recebimento e armazenamento dos alimentos, enfocando os critérios para a escolha dos fornecedores, recebimento das matérias primas, forma de armazenamento dos alimentos, higiene 
pessoal, controle de temperatura durante a cocção dos alimentos e depois, na área de venda, além dos procedimentos de higiene dos equipamentos e utensílios.

Mesmo aos estabelecimentos que não fazem qualquer manipulação no alimento como os bares, que apenas comercializam produtos industrializados, é importante que sejam abordados os assuntos acima.

A questão 4, referia-se ao número de funcionários presentes nos estabelecimentos. Constatou-se que em 27 pontos de venda há apenas o proprietário; em 30 há entre um e dois funcionários e, em 9 estabelecimentos existem mais de dois funcionários (gráfico 6). O número máximo de funcionários por estabelecimento foi 8 , em apenas um estabelecimento. Do total de estabelecimentos com mais de um funcionário (39 estabelecimentos, ou 59,1\%) 87,4\% deles possuem apenas membros da família trabalhando no local, em um estabelecimento o funcionário não tem parentesco, e nos outros quatro, trabalham parentes e não parentes do proprietário.

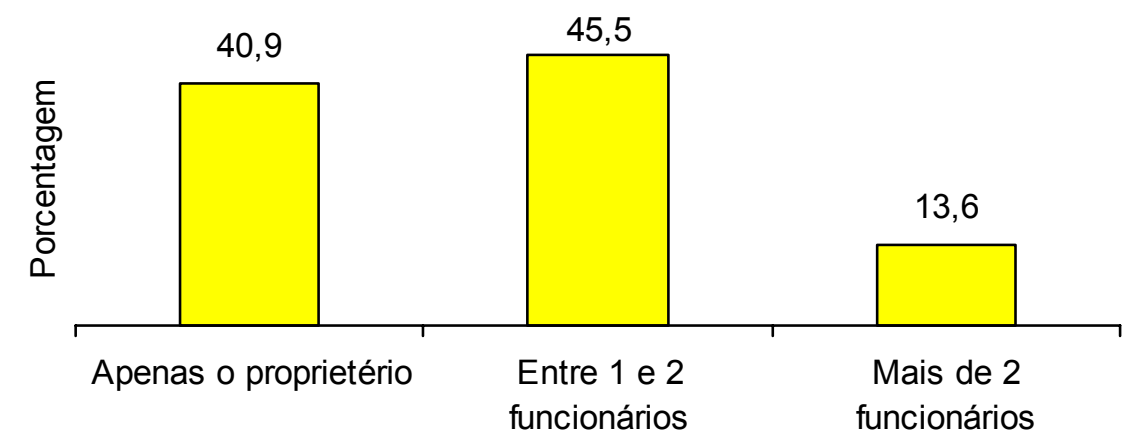

Gráfico 6- Número de funcionários dos estabelecimentos entrevistados na Comunidade São Remo, São Paulo, 2001.

Fica caracterizado que a Comunidade dispõe somente de estabelecimentos de pequeno porte e, em sua maioria, de natureza familiar, possibilitando trabalho para vários membros da família.

“Em países pobres, os processos em pequena escala, que são os principais responsáveis pela produção, estocagem, distribuição e venda de alimentos, estão baseados 
em suprimento de água imprópria, ambiente anti-higiênico e uso inadequado ou deficiente de técnicas de embalagem e estocagem. Além disso, o suprimento de energia elétrica é deficiente e pode prejudicar os esforços para a preservação dos alimentos na geladeira ou freezer" (IGBEDIOH, \& AKINYELE, 1992).

A presença de um grande número de familiares trabalhando no estabelecimento evidencia a falta de critérios relevantes para a admissão dos funcionários no estabelecimento. De acordo com a ASSOCIAÇÃO BRASILEIRA DE PROFISSIONAIS DA QUALIDADE DE ALIMENTOS-PROFIQUA,1995, todas as pessoas que tenham contato com o processo, matérias primas, material de embalagem, produto em processo e produto terminado, equipamentos e utensílios devem ser treinadas e conscientizadas a praticar as medidas de higiene e segurança de produto para proteger os alimentos de contaminações químicas, físicas e microbianas. Este assunto foi abordado na questão 9, onde perguntou-se se o proprietário passava algum tipo de instrução aos seu funcionários. A questão não especificou se eram instruções relativas aos alimentos, além disso, era uma questão aberta e as respostas foram agrupadas (tabela 9). Vinte e um proprietários de estabelecimentos, 31,8\% oferecem algum tipo de orientação para o trabalho, para seus funcionários e somente $15 \%$ destes (três entrevistados) oferecem instruções relativas ao tema higiene. Percebemos então a falta de capacitação dos funcionários para lidar com os alimentos.

Tabela 2- Temas relevantes para os funcionários que manipulam alimentos citados pelos proprietários de estabelecimentos que comercializam alimentos na Comunidade São Remo,São Paulo, 2001

\begin{tabular}{ccc}
\hline Orientação ao funcionário & $\mathbf{n}^{\circ}$ respostas & \% respostas \\
\hline Higiene & 3 & 15 \\
Atendimento & 4 & 20 \\
Atendimento, manipulação & 4 & 20 \\
Recebimento/Armazenamento & 3 & 15 \\
Higiene/atendimento & 1 & 5 \\
Troco certo/Não vender fiado & 3 & 15 \\
Outros & 2 & 10 \\
\hline \hline
\end{tabular}




\section{Total}

20

100

Sobre o item Atendimento/manipulação, os entrevistados diziam ensinar ao funcionário aquilo que eles sabiam, proveniente de empregos e experiências anteriores, como foi o caso do proprietário de um açougue que relatou orientar seus funcionários o procedimento de desossa.

A questão 13 abordou a presença e o controle de insetos e roedores. Trinta e oito comerciantes $(57,6 \%)$ afirmaram já ter observado ratos e/ou baratas em seu estabelecimento. $60,5 \%$ relataram terem feito uso de ratoeiras ou raticidas/inseticidas comerciais; $9,3 \%$ relataram que mataram a praga, quando encontrada; $4,7 \%$ citaram realizar a retirada de lixo e reparos nas edificações, como vedação de frestas; $20,9 \%$ referiram o uso de serviços de controle de pragas realizado por terceiros e 4,7\% não tomaram nenhuma providência . A área externa, se não for livre de acúmulo de entulhos e não possuir adequado destino do esgoto pode agravar o problema de pragas. De acordo com (TASCHNER, 1997), a ausência de infra-estrutura sanitária nas favelas de São Paulo é dramática, com 56\% dos domicílios em 1987 e 77,1\% em 1993 lançando dejetos ao ar livre e/ou diretamente a córregos ou represas.

Pelos relatos, supõe-se que a ocorrência de pragas em uma Comunidade como a São Remo é constante. A aplicação do Programa de Controle Integrado de Pragas prevê um conjunto de ações fundamentais que visam eliminar ou minimizar os riscos de ocorrência de insetos, roedores e pragas de grãos. De maneira geral, é necessário impedir o acesso, dificultar a permanência e não oferecer alimento e abrigo para estes animais. São diversas as recomendações, desde as instalações, que devem ser livres de possíveis entradas de pragas no ambiente, como falhas de vedação em tubulações, ralos sem proteção, portas e janelas mal vedadas e sem telas; livres de azulejos mal assentados ou quebrados, onde as pragas podem se alojar ou onde há acúmulo de 
resíduos difíceis de limpar; ausente de vazamentos e água empoçada; ausente de entulhos e materiais sem uso dentro e nas imediações do estabelecimento; com acondicionamento adequado do lixo; limpeza rigorosa dos equipamentos, utensílios e instalações, para que não deixem resíduos que servirão de alimentos para os insetos e roedores e armazenamento em condições adequadas. (GIORDANO, 2002).

\section{Caracterização da Matéria-Prima}

A qualificação dos fornecedores e o recebimento das matérias-primas são etapas bastante importantes no controle da higiene e qualidade dos alimentos. É interessante visitar o fornecedor e solicitar documentos com relação à procedência dos alimentos, observar as condições de armazenamento dos produtos além da higiene e organização do local, atentando às características das instalações, da área externa e à presença ou não de vestígios de insetos e roedores. Um armazenamento incorreto desde o fornecedor coloca o alimento em risco e mesmo que se façam todos os controles necessários no próprio estabelecimento, não é possível recuperar a qualidade e inocuidade perdidas. $\mathrm{O}$ mesmo vale para o transporte, que deve ser apropriado para o tipo de alimento que está sendo transportado, os entregadores devem estar devidamente uniformizados e os alimentos devem ser transportados em temperaturas adequadas de acordo com a exigência de cada um. As questões 6 e 7 levantaram aspectos importantes relacionados à aquisição de matérias-primas e produtos a serem comercializados. Sobre a questão 7, que indagava sobre a forma de aquisição da matéria-prima, dez proprietários $(15,2 \%)$ responderam que adquirem matérias-primas de fornecedores que entregam diretamente os produtos em seus estabelecimentos. Desta forma não conhecem as suas instalações; 42 proprietários $(63,6 \%)$ compram pessoalmente seus 
produtos em diferentes pontos de venda e 14 pessoas $(21,2 \%)$ responderam utilizar as duas formas anteriormente citadas para adquirir produtos.

Quanto aos critérios usados para aquisição da matéria prima, os mais observados constam no gráfico 7 , atentando que o preço é ainda fator preponderante na escolha dos produtos.

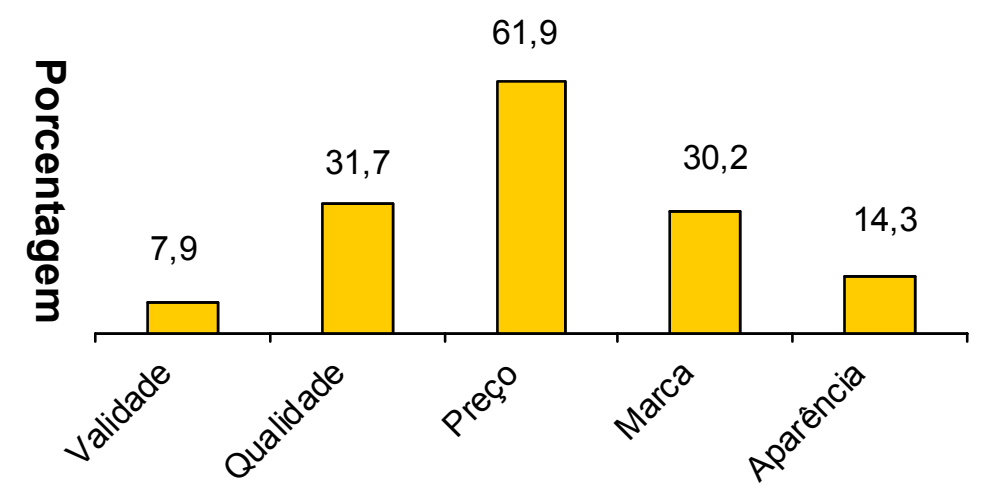

Gráfico 7- Critérios utilizados para a aquisição de matérias primas pelos comerciantes da Comunidade São Remo, São Paulo, 2001.

Quanto a questão 6, onde os entrevistados eram perguntados se costumavam olhar o rótulo dos produtos, e, se sim, o que procuraram, a maioria 77,3\% (51) dos entrevistados relata ler o rótulo dos produtos que adquire. Deste total, 85,2\% observam apenas a data de validade, 5,6\% atentam para a validade e composição do alimento e 9,3\% procuram informações quanto à validade e outros aspectos, como marca, características da embalagem, para que serve, como utilizar o produto e se são produtos são nacionais ou importados. No momento da compra ou do recebimento da mercadoria devem ser observadas as condições do transporte, como mencionado anteriormente e características dos produtos, como integridade das embalagens, data de validade, temperatura (se está de acordo com o especificado pelo fabricante), procedência 
(registro no serviço de inspeção federal ou estadual no caso dos produtos de origem animal), itens que não foram citados nas entrevistas. A temperatura dos alimentos, principalmente os perecíveis deve ser checada com o auxílio de um termômetro a fim de certificar com exatidão a manutenção correta deste alimento pelo fornecedor.

O item c) da questão 7 abordava critérios para inutilização ou devolução de produtos.Vinte e um $(31,8 \%)$ entrevistados já devolveram ou inutilizaram alguma matéria-prima, pelos seguintes motivos: Produto vencido (6), produto estragado ou velho (4), embalagem danificada ( 3) (gráfico 8). Trata-se de um número relativamente alto e que pode ser minimizado adotando-se as medidas citadas para o recebimento e armazenamento, não adquirindo grande quantidade de produtos, procedendo ao empilhamento correto dos produtos, garantindo a ventilação entre os mesmos e a saída dos produtos mais próximos ao vencimento antes dos outros.

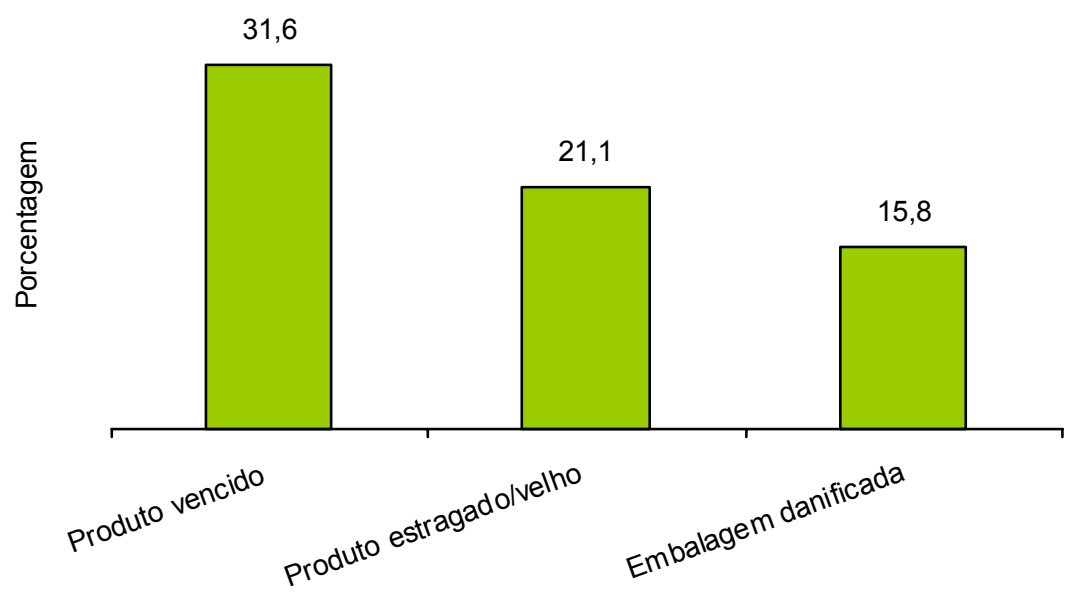

Gráfico 8- Causas relatadas pelos comerciantes de alimentos da Comunidade São Remo para a devolução de produtos alimentícios, São Paulo, 2001. 


\section{Conhecimentos sobre Higiene}

A questão 10 pergunta se a falta de higiene durante a preparação dos alimentos pode causar doenças ou mal estar nas pessoas. Sessenta entrevistados (90,9\%) acreditam que sim. Dentre as respostas que ilustram a concepção de falta de higiene por parte dos entrevistados ,item a) da mesma questão, obteve-se: não lavar as mãos (51); não guardar os alimentos na geladeira (29); não cozinhar os alimentos adequadamente (34) e outros (55), onde a afirmação "Não lavar os alimentos adequadamente", referindo-se tanto para os vegetais quanto para produtos cárneos foi a mais citada. Os valores em porcentagem encontram-se no gráfico 9. Outras afirmações como não lavar os utensílios, reaproveitar embalagens, fumar cigarro, ter barba e unhas compridas, apareceram como respostas a essa questão. Todas as respostas citadas ilustram procedimentos anti-higiênicos e que podem colocar os alimentos em situação de risco de contaminação e proliferação de bactérias, exceto a lavagem das carnes, prática que não tem nenhuma eficácia na destruição de bactérias e que ainda contribui para a remoção de nutrientes da superfície do alimento. É importante explorar mais o conceito de higiene e ilustrar a razão pela qual tais procedimentos são um risco para o alimento, citando a presença dos três tipos de contaminação, física (presença de corpos estranhos no alimento), química (presença de resíduos de agrotóxicos, venenos, produtos de limpeza entre outros) e principalmente a biológica (presença de bactérias, fungos, parasitas e outros organismos que podem causar doenças). 


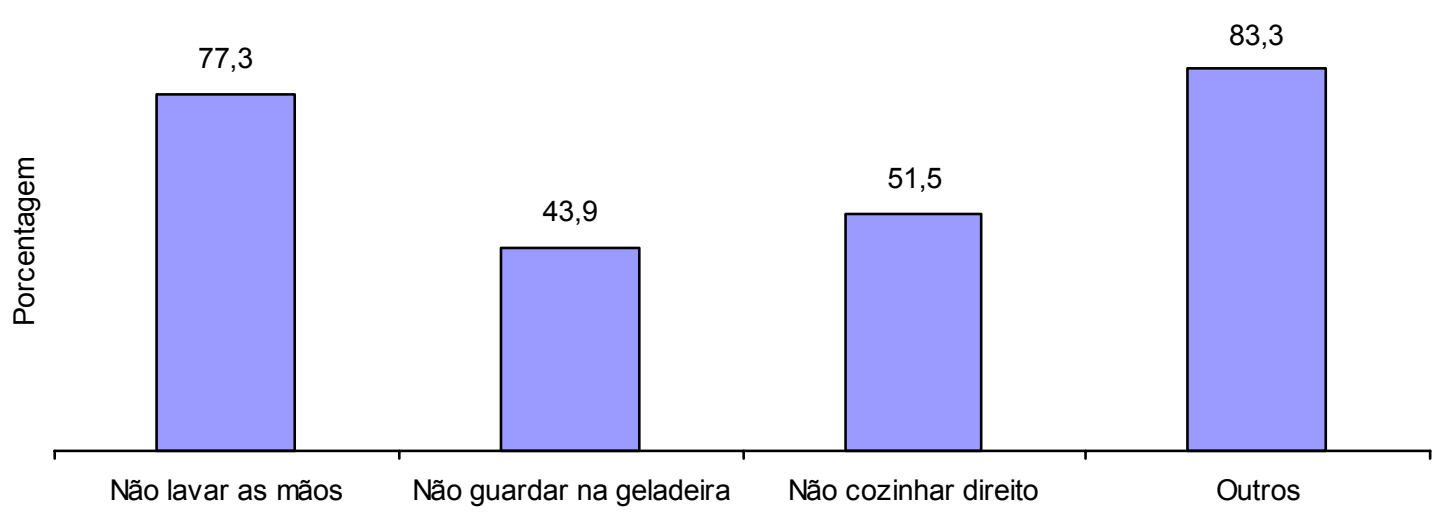

Gráfico 9- Situações e procedimentos relatados pelos proprietários de estabelecimentos de alimentos, como responsáveis por situações onde os alimentos podem causar danos à saúde do consumidor, São Paulo, 2001.

Quando perguntados sobre qual o principal cuidado na hora de cozinhar (questão 11), obtivemos as seguintes categorias de respostas: Cuidados com os utensílios (jogar água quente nas panelas antes de usá-las, por exemplo): (11); Higiene pessoal (lavar as mãos, usar touca ou boné, usar avental e luva, manter unhas cortadas e limpas): (35); Higiene geral ou com os alimentos (tampar as panelas, olhar a validade dos produtos, colocar no congelador, manter os alimentos bem embalados etc): (26) e Higiene do ambiente (8). Um entrevistado relatou não tomar nenhum cuidado (gráfico $10)$.

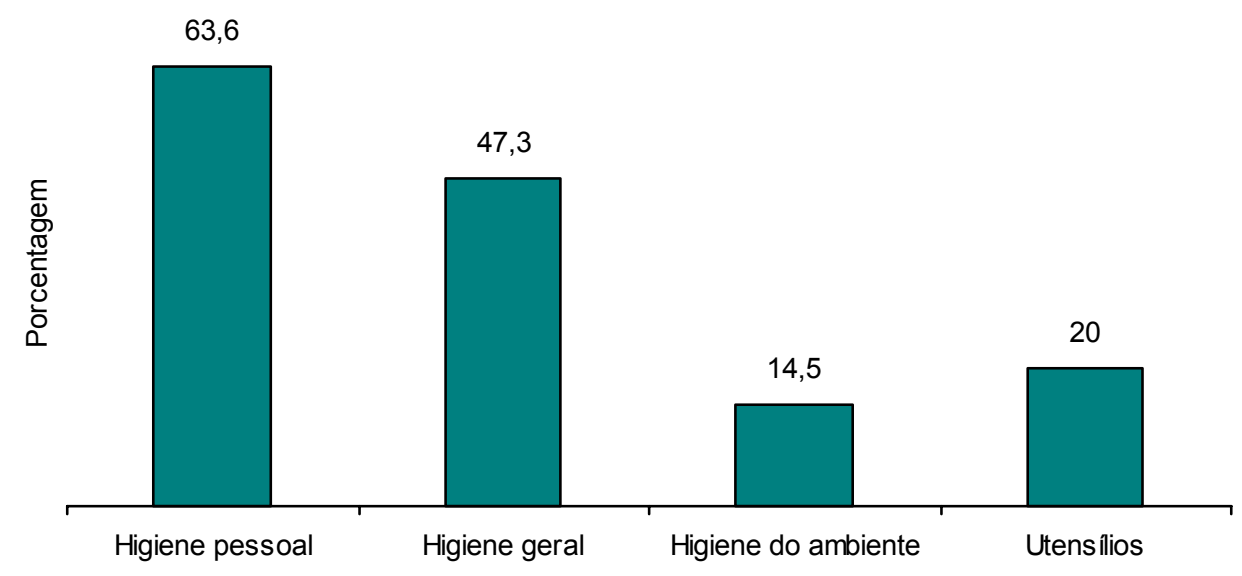

Gráfico 10- Principal cuidado que o proprietário de estabelecimento de alimentos tem na hora de cozinhar, São Paulo, 2001. 
Mais de $50 \%$ das pessoas citaram higiene pessoal como um dos principais cuidados que toma. Isso é uma informação importante uma vez que o manipulador contribui com $12 \%$ das causas de ocorrência de surtos de doenças de origem alimentar. (FORSYTHE, 2002) e foi responsável por 55\% dos fatores contribuintes para a ocorrência de surtos de intoxicação alimentar no Paraná de 1978 a 1999. (MANUAL de elementos de apoio para o sistema APPCC, 2001). O principal agente relacionado ao manipulador é o Staphylococcus aureus, presente nas mucosas, pele e feridas dos seres humanos. (UDO, 1999). Cerca de 3,8 a 35,3\% dos manipuladores carregam S. aureus em suas mãos (MIWA, 2001). Este microrganismo é capaz de se proliferar e produzir toxina termoestável, isto é, mesmo com o cozimento ou reaquecimento do produto, a toxina permanece e causa doença com sintomas como náuseas, vômitos, dor abdominal e diarréia e em um curto período de incubação ( 2 a 6 horas após a ingestão da toxina pré-formada) (BALABAN, 2001). Apesar disso, restam quase 50\% dos entrevistados que não citaram este item, sendo um valor considerável e que deve ser incansavelmente abordado em treinamentos e projetos educativos futuros.

Com relação à questão $\mathrm{n}^{\mathrm{o}} 12$ sobre se o entrevistado tem muita perad com alimentos estragados, a maioria 86,4\% (57 entrevistados) respondeu que não. Para evitar a perda, item a) da questão, os procedimentos tomados são: Guardar na geladeira (47\%), guardar os alimentos no freezer $(42,4 \%), 43,9 \%$ fazer ou comprar uma quantidade pequena de alimentos. O conceito estragado foi usado exatamente para diferir do conceito de contaminado, afinal, só se descarta um alimento quando existem alterações organolépticas, isto é, de cor, sabor, cheiro e aparência, alterações estas, características de microrganismos deteriorantes e não dos patogênicos, foco do estudo. De qualquer forma, a pergunta serviu para definir os procedimentos das pessoas em relação a conservação dos alimentos: ficam muito tempo na geladeira? São 
descongelados e recongelados? Quase não produz sobras? As mesmas são descartadas? As respostas obtidas estão muito próximas, sendo possível concluir que existe uma preocupação com a quantidade de alimento preparado, mais no sentido de se evitar o desperdício de alimentos. Resta discutir mais a respeito dos critérios de reaproveitamento de sobras no comércio de alimentos, formas de identificação dos alimentos para que sejam armazenados, validades dos alimentos após manipulação, disposição dos alimentos na geladeira, formas de descongelamento, entre outros, de acordo com a legislação, principalmente a Portaria CVS 06/99, que aborda estes e outros aspectos de boas práticas de manipulação (BRASIL, 1999).

Procedimentos de limpeza

As questões de número 14 a 16 são relacionadas aos procedimentos de limpeza do estabelecimento em si e dos equipamentos, tendo sido solicitadas informações a respeito da freqüência destes procedimentos e dos tipos de produtos utilizados. Este é um item importante nas boas práticas, já que uma higienização inadequada não elimina ou sequer reduz os riscos microbiológicos dos equipamentos, utensílios e superfícies. Entende-se por higienização os procedimentos de limpeza e desinfecção necessários para assegurar que os alimentos cheguem ao consumidor em condições apropriadas para o consumo. Limpeza é definida como a remoção de sujidades de qualquer superfície suja e desinfecção é o ato ou efeito de eliminar os microrganismos presentes na forma vegetativa (ASSOCIAÇÃO BRASILEIRA DE PROFISSIONAIS DA QUALIDADE DE ALIMENTOS-PROFIQUA, 1995).

Os produtos utilizados para limpeza dos utensílios, citados pelos entrevistados encontram-se no gráfico 11 e são, principalmente: detergente (tendo sido citado por 50 
comerciantes que responderam à pergunta) e sabão, citado 4 vezes. Os produtos ou procedimentos utilizados para higienização do piso são : pano úmido (17), vassoura (3) cândida (22), sabão em pó (25), água (19), desinfetante (22), detergente (9), cera (2). A freqüência de limpeza do piso dos estabelecimentos é de uma vez por dia para $43,4 \%$ (28) dos comerciantes e uma ou mais de uma vez por semana para a mesma quantidade de pessoas. 9,4\% (6) tem uma freqüência de mais de uma vez por dia. Foi relatada a aquisição dos produtos de limpeza vendidos a granel, em automóveis, tratando-se de produtos sem registro no ministério da agricultura, e sem a rotulagem adequada, que deve indicar o princípio ativo presente no produto, concentração, diluição e forma de uso do mesmo. Não é possível saber se os procedimentos de limpeza e desinfecção são efetivos com o uso destes materiais.

Dos estabelecimentos pesquisados, 68,2\% (45) possuem banheiro. Sendo 88,6\% destes (39), apresentando apenas um banheiro, 9,1\% tem dois banheiros e 2,3\% (apenas um estabelecimento) apresenta 3 banheiros. A freqüência de limpeza dos banheiros é de uma vez por dia para $62,2 \%$ dos estabelecimentos, uma ou mais de uma vez por semana $(22,2 \%)$ e mais de uma vez por dia para $11,1 \%$. Os produtos utilizados são sabão (19), cândida (28), água (10), detergente (5), álcool (2), desinfetante/pinho sol (25) e pano úmido (4) (gráfico 11). Os sanitários são áreas importantes do estabelecimento porque também serão utilizados pelo manipulador de alimentos, e se não estiverem em boas condições de limpeza e se não oferecerem condições para uma adequada higienização das mãos, contribuirão para que o manipulador seja um importante foco de contaminação dos alimentos. 


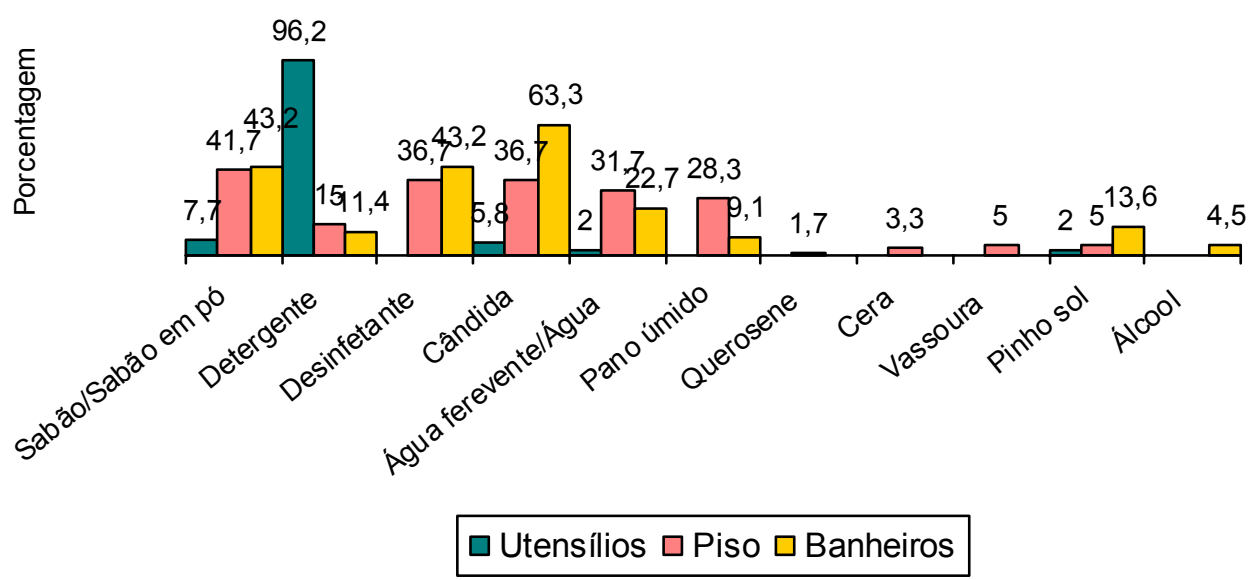

Gráfico 11- Produtos utilizados para a limpeza e desinfecção dos utensílios, piso e banheiros nos estabelecimentos de alimentos da Comunidade São Remo. São Paulo, 2001.

Alguns entrevistados demonstraram considerar a higiene do banheiro algo de grande importância, referindo-se ao sanitário como um "espelho" do estabelecimento. Além da limpeza, outros itens são importantes no sanitário dos funcionários do estabelecimento. Seguindo a Portaria CVS 06/99, deve haver sabonete líquido, papel toalha, lixeira e vasos com tampa e porta com mola. O manipulador deve ter condições adequadas de higienização das mãos após usar o banheiro.

De acordo com a referida portaria, a limpeza do piso e dos sanitários deve ser diária, sendo as etapas do processo de higienização ambiental: lavagem com água e sabão ou detergente, enxágüe, desinfecção química: deixar o desinfetante em contato mínimo de 15 minutos, enxágüe. O detergente desempenha papel básico nos processos de limpeza, reduzindo o tamanho e separando as partículas de resíduos e removendo as sujidades sem induzir a corrosão dos materiais submetidos à limpeza. A etapa de desinfecção com agente sanitizante tem por objetivo promover a redução dos microrganismos da flora normal e patogênica presentes nas superfícies dos 
equipamentos que entram em contato com os alimentos. A maioria dos agentes sanitizantes, tais como Quaternários de amônio, compostos inorgânicos do cloro e iodóforos não é efetiva se houver matéria orgânica presente na superfície (alimentos, sujeira). (ASSOCIAÇÃO BRASILEIRA DE PROFISSIONAIS DA QUALIDADE DE ALIMENTOS-PROFIQUA, 1995). O procedimento realizado pelos proprietários é, portanto, insuficiente para eliminar efetivamente os riscos microbiológicos da edificação, equipamentos e utensílios dos estabelecimentos.

Conhecimentos sobre micróbios e bactérias

As perguntas a seguir ( número 17, itens $\mathrm{a}, \mathrm{b}, \mathrm{e} \mathrm{c}$ ), referiam-se às bactérias $\mathrm{e}$ foram formuladas de modo a não interferir ou induzir a resposta dos entrevistados. Quando perguntados se já haviam ouvido falar em micróbios e bactérias, 65 (98,5\%) apresentaram resposta afirmativa e apenas um relatou nunca ter ouvido falar. A primeira palavra que vem à cabeça das pessoas quando pensam em bactérias foi categorizada, mostrando os seguintes grupos de respostas, que encontram-se na tabela 3:

Tabela 3- Palavras associadas às bactérias de acordo com os proprietários de estabelecimentos da Comunidade São Remo. São Paulo, 2001

\begin{tabular}{ccc}
\hline PALAVRA & FREQUENCIA & PORCENTAGEM \\
\hline \hline Doença & 20 & 31,7 \\
Falta de higiene, sujeira & 15 & 23,8 \\
Prevenir, ter limpeza & 6 & 9,5 \\
Combater & 2 & 3,2 \\
Relacionada a onde estão & 1 & 1,6 \\
Bichinho, verme, micróbio & 14 & 22,2 \\
Não sei, não existe & 5 & 7,9 \\
\hline \hline Total & 63 & 100 \\
\hline
\end{tabular}


A palavra doença foi citada ou mencionou-se alguma doença específica, como cólera e diarréia, entre outras.

O item a) questionou a respeito dos locais onde os entrevistados julgavam poder encontrar as bactérias (Gráfico 12).

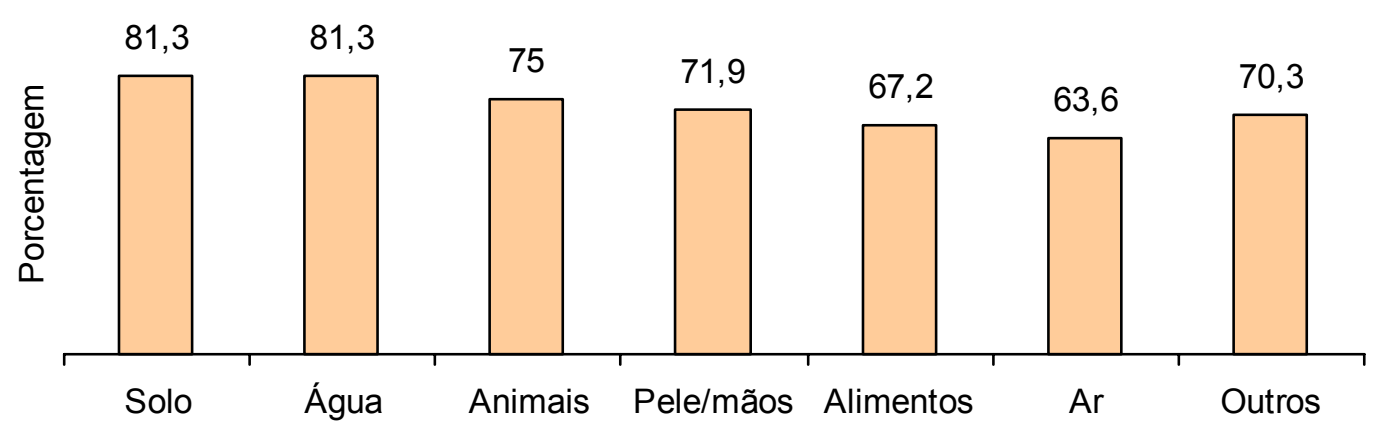

Gráfico 12- Locais onde as bactérias podem ser encontradas segundo os comerciantes da Comunidade São Remo. São Paulo, 2001.

Referindo-se à água, alguns citavam a água parada como fonte de microrganismos; a respeito dos alimentos, foram citados alimentos velhos ou frutas e verduras e com relação ao item "Outros", o mais citado era "todos os lugares", banheiro e esgoto. Dependendo do tipo de microrganismo, existem locais considerados reservatórios naturais de microrganismos, tais como o solo, reservatório natural do Bacillus cereus e dos Clostridios, seres humanos, no caso do Staphylococcus aureus, água, abrigando o $V$. cholerae, (sendo aparentemente o homem seu reservatório), animais como reservatórios do Campylobacter jejuni, entre diversos outros (Projeto APPCC Mesa, 2001). Os microrganismos citados não são encontrados exclusivamente nesses locais.

Com relação às formas de destruição das bactérias, as respostas em porcentagem encontram-se no Gráfico 13. Cozinhando, (se o alimento pudesse ser cozido): 45, Apenas 18 pessoas consideraram o resfriamento dos alimentos um bom método para se combater os microrganismos, tendo encontrado comentários de que o frio apenas 
conserva os alimentos. 43 entrevistados consideraram que lavando as mãos, as bactérias das mãos podiam ser destruídas. Se estivessem na água, 52 referiram o processamento térmico (fervura) como método de destruição, 4 pessoas mencionaram a filtração. Lavar o chão foi considerada a forma de combate das bactérias presentes neste local por 50 pessoas. Foram citados como "outros", respostas como "lavando os alimentos", uso de cloro na água, remédios e vacinas, higiene e limpeza, creolina e veneno, somando 32 respostas. Temperaturas acima de $75^{\circ} \mathrm{C}$ são capazes de destruir a maioria das formas vegetativas das bactérias constantes em todos os grupos (psicrotróficas, mesófilas-onde a maioria das patogênicas se encontra e termófilas). As formas esporuladas e as toxinas produzidas por algumas bactérias apresentam maior resistência ao calor, não sendo destruídas pela cocção (GERMANO, 2001). Quanto à refrigeração, este procedimento não tem a capacidade de destruir bactérias. Alguns grupos, como os mesófilos, psicrófilos e psicrotróficos podem multiplicar-se em temperaturas de $0^{\circ} \mathrm{C}$ ou até menos. Essas temperaturas, no entanto não são as ideais para a multiplicação destas bactérias, e portanto a velocidade de multiplicação será menor, conservando o alimento por mais tempo (GERMANO, 2001).

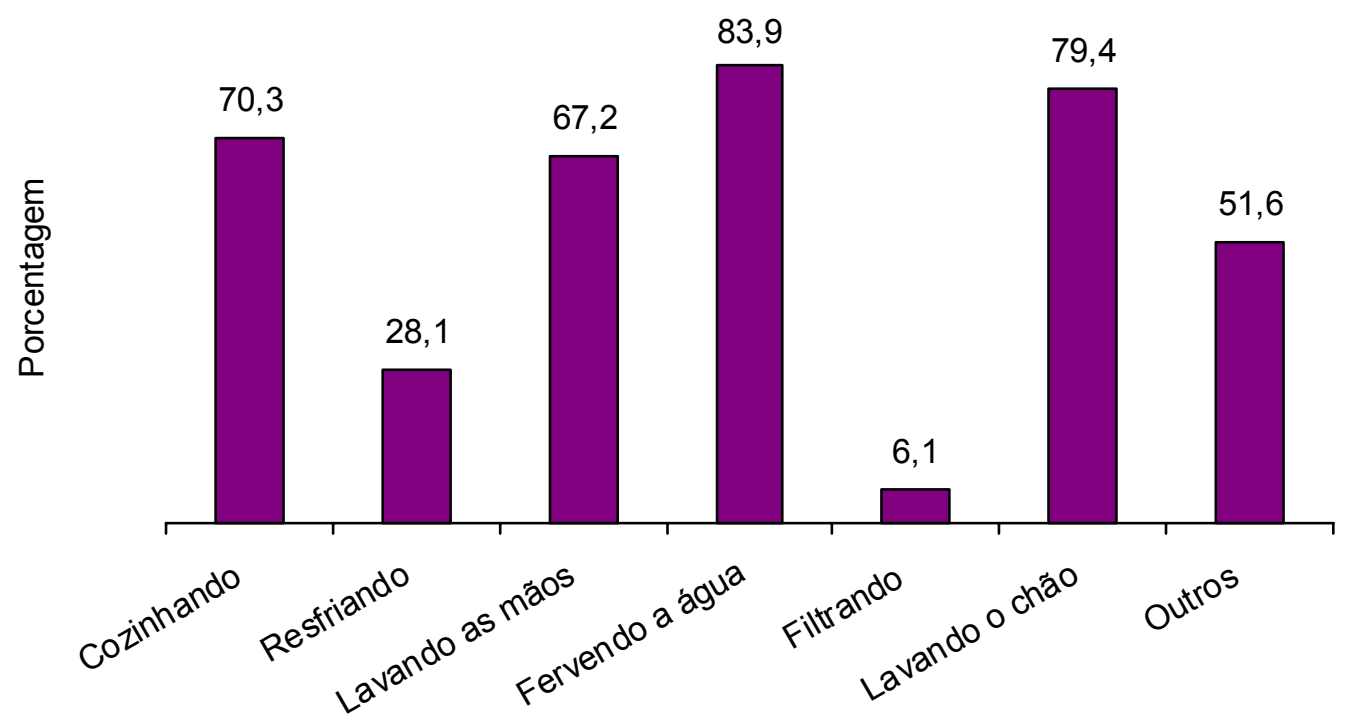

Gráfico 13- Formas para destruir as bactérias na opinião dos comerciantes de alimentos da Comunidade São Remo. São Paulo, 2001. 
O que podemos perceber, com relação às bactérias, é que a maioria sabe de sua existência, mas tem uma idéia um pouco vaga a seu respeito, não sabendo definir exatamente o que são, mas citando alguns efeitos que elas causam. Sobre os alimentos, especificamente, as pessoas em geral consideram o aquecimento e mesmo o resfriamento como técnicas para destruição dos microrganismos e esquecem de citar (e mais ainda, realizar) as boas práticas como forma de prevenir a contaminação e proliferação das bactérias nos alimentos. É essa visão de prevenção e de considerar as bactérias como um inimigo permanente e iminente na cozinha que o treinamento e as orientações devem oferecer.

Características da comunidade e das impressões do comerciante com relação à comunidade

As questões seguintes (18 a 21) têm o intuito de ouvir o que os entrevistados tem a dizer a respeito da sua Comunidade, dos problemas que ele enfrenta enquanto comerciante de alimentos e das possíveis soluções. A partir daí torna-se mais fácil o acesso e a reunião dessas pessoas, com a proposta inicial de discutir aquilo que eles consideram problema, e não aquilo determinado pelo pesquisador e que não é visto como um problema pelo comerciante. Este é um fator importante que faz com que muitos projetos de extensão não dêem certo. Segundo SAITO (in OLIVAL, 2002) um processo que não leva em conta aspectos pré-existentes de atitudes, interesses e necessidades das pessoas envolvidas, não pode ser considerado como um projeto comunicativo. Entendendo comunicação como a troca de significados entre um emissor e um receptor, num processo de interação social. 
A proposta, portanto, consiste em reunir um grupo com interesses comuns para discutir e juntos chegar a soluções comuns, introduzindo o que é considerado importante também pelo pesquisador, mas com uma postura diferente, onde ele é parte integrante do grupo, emitindo suas opiniões e ouvindo o que todos tem a dizer. Isso concorda com a idéia de FREIRE, 1999 (in OLIVAL, 2002), na qual todo educador (no caso o pesquisador) deve priorizar a participação ativa dos educandos dentro do processo educativo e de VASCONCELOS (2001), que afirma que as carências que motivam o esforço dos indivíduos e grupos passam necessariamente pela subjetividade e pela cultura. As necessidades são, portanto, também construídas e redefinidas nas práticas educativas, mas, em práticas educativas que não partam do pressuposto da existência de uma associação linear entre a vontade da população e as carências materiais definidas pela ciência (Vasconcelos, 2001).

A questão 18, referente à existência e participação do entrevistado em grupos de discussão na comunidade permite traçar mais uma característica da Comunidade: existe já um caminho aberto às discussões? Existem grupos interessados em discutir os problemas da Comunidade? A não existência destes grupos não significa exatamente falta de interesse em discutir problemas, mas principalmente falta de motivação uma vez que a maioria das reuniões é reconhecida com algo que só toma tempo e não chega a lugar nenhum. Isso porque a estrutura dos grupos de discussão e de educação necessitam de mudanças, estão ainda muito baseadas na estrutura de professor e aluno, na qual o primeiro deposita conhecimentos sobre o segundo, que os armazena, sem reflexão. Segundo FREIRE, 1979 in OLIVAL, 2002, é preciso que a educação esteja , em seus programas e métodos, adaptada ao fim que se persegue: permitir ao homem chegar a ser sujeito, construir-se como pessoa, transformar o mundo, estabelecer com os outros homens relações de reciprocidade, fazer cultura e fazer história. 
Sobre a existência de associação de comerciantes na comunidade, apenas cinco pessoas $(7,6 \%)$ responderam haver associação, uma entrevistada mencionou a existência de uma cooperativa localizada no circo escola localizado no interior desta comunidade, outro citou a existência de "combinações" entre os comerciantes, sem reuniões. Apenas duas pessoas afirmaram haver reuniões desses grupos, um deles informou horário e local e o outro afirmou que existe, mas não participa. Esses locais informados não foram investigados, mas de qualquer forma percebemos haver pouca articulação entre os comerciantes da comunidade, cada um enfrentando seus problemas e resolvendo-os individualmente, sendo que em muitos casos a união, as discussões, as conclusões atingidas e principalmente as ações tomadas pelo grupo podem ter efeito muito maior.

Os problemas existentes na comunidade, segundo os entrevistados, foram categorizados e colocados em forma de uma tabela (tabela 4). Tudo o que foi citado deve ser levado em consideração na elaboração de um projeto educativo e deve ser colocado em discussão, quando houver esta oportunidade, permitindo a troca de idéias e de experiências bem ou mal sucedidas. Um grande número de comerciantes, 57,8\%, relatou não enfrentar nenhum problema, indicando a falta de incentivo à reflexão sobre sua própria situação e conseqüentemente sobre melhores as maneiras de enfrentá-los. Como "outros", foram citados violência, crianças na rua e reclamações dos usuários.

Tabela 4- Problemas na Comunidade enfrentados pelos proprietários de estabelecimentos da Comunidade São Remo. São Paulo, 2001

\begin{tabular}{c|c|c}
\hline PROBLEMA CITADO & FREQUÊNCIA & PORCENTAGEM \\
\hline \hline Nenhum & 38 & 57,6 \\
Fiado & 7 & 10,6 \\
Usuários & 1 & 1,5 \\
Fiado e usuários & 1 & 1,5 \\
Concorrência & 5 & 7,6 \\
Outros & 13 & 19,7 \\
Não respondeu & 1 & 1,5 \\
\hline Total & 65 & 100 \\
\hline \hline
\end{tabular}


As soluções apontadas para os problemas citados (questão 20),encontram-se na tabela

5. Dentre as pessoas que responderam a essa pergunta, apenas uma citou a discussão e participação como solução. Outras respostas transferiam a solução para outras pessoas entidades ou não se vislumbrava alguma solução possível. Quando esses problemas são discutidos em grupo, percebe-se que não é um problema isolado e diversas soluções possíveis começam a surgir.

Tabela 5- Soluções apontadas pelos proprietários de estabelecimentos da Comunidade São Remo. São Paulo, 2001

\begin{tabular}{ccc}
\hline SOLUÇÕES CITADAS & FREQUÊNCIA & PORCENTAGEM \\
\hline \hline Não vender fiado, atender bem & 5 & 7,6 \\
Discutir, participar & 1 & 1,5 \\
Governo, Deus, esperar & 8 & 12,1 \\
Não tem solução, não se mete & 6 & 9,1 \\
Não sabe, outros & 5 & 7,6 \\
Não respondeu & 41 & 62,1 \\
\hline Total & 66 & 100 \\
\hline \hline
\end{tabular}

A questão 21 era sobre o que o proprietário mudaria em seu estabelecimento. $32,3 \%$ (21) não querem mudar nada, estão satisfeitos com seu estabelecimento; $40 \%$ realizariam reformas no sentido de ampliar ou mudar o visual do comércio; 18,5\% (12 pessoas) querem mudar o tipo de comércio, porém, continuando a comercializar alimentos; 3,1\% (2) querem mudar o tipo de comércio não mais comercializando alimentos (gráfico 14). Levando em conta que a maioria dos comerciantes de alimentos deseja manter este comércio e muitos planejam inclusive promover reformas, percebemos a importância de um projeto educativo que consiga incrementar a qualidade dos alimentos comercializados na comunidade. A edificação deve ser discutida, tentando adequar ao máximo o estabelecimento na legislação vigente. 


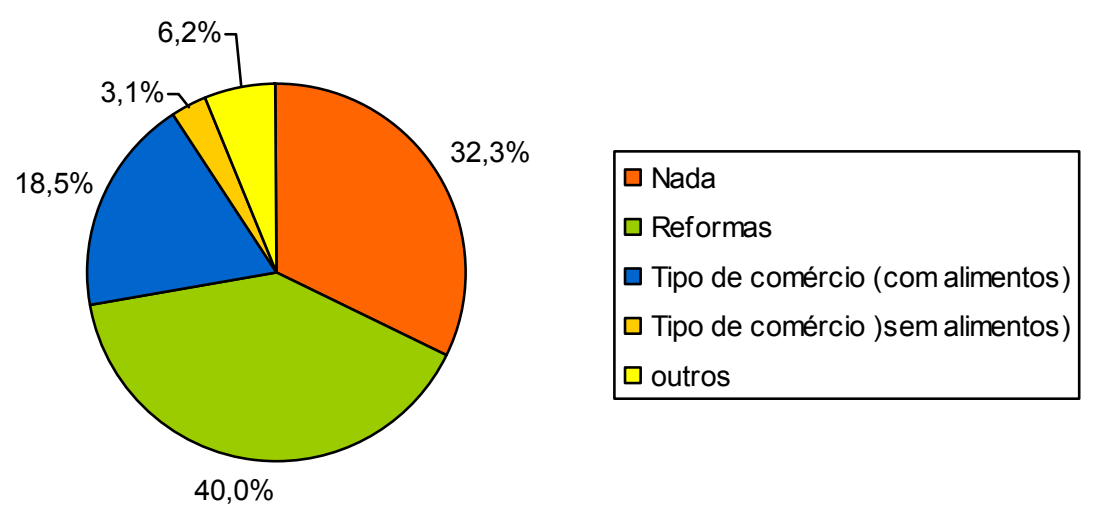

Gráfico 14- Alterações que os proprietários gostariam de fazer em seus estabelecimentos, São Remo, São Paulo, 2001.

Receptividade para projetos educativos

Após cerca de 15 a 30 minutos de entrevista, os entrevistados estavam ou mais interessados no assunto ou bastante dispersos. A questão 22 desejava saber se há interesse em discutir mais a respeito dos alimentos, uma vez que essas pessoas serão nosso público-alvo. Quarenta e quatro entrevistados $(67,7 \%)$ tem interesse em saber mais sobre a questão da higiene com os alimentos. A questão 23 era a respeito do profissional indicado para falar sobre esse assunto, onde $37,9 \%$ responderam saber qual era o profissional, tendo sido citados: nutricionista 46,4\% (13), médicos, biólogos e outros profissionais de saúde 7,1\% (2), feirante, cozinheiro ou pessoa que trabalha com alimentos 25\% (7), 10,7\% (3 pessoas apenas) citaram uma pessoa conhecida da comunidade ou da própria família. Conhece-se muito pouco o papel do médico veterinário na área de alimentos e esta seria também uma oportunidade de divulgar mais esta área de atuação. Além disso, todos os citados tem algum conhecimento sobre os alimentos e pode expor seu ponto de vista durante o processo educativo. 
Noções de legislação, vigilância sanitária e análise de alimentos

As questões referentes a legislação na área de alimentos (questão 24) e ao serviço de vigilância sanitária (questão 25) foram feitas porque existem diversas leis na área de alimentos e porque o serviço de vigilância sanitária existe há muito tempo e todos os estabelecimentos de alimentos deveriam conhecer essas leis e esse serviço, preocupando-se em estar e manter-se adequado. Do total de entrevistados, $65,2 \%$ nunca ouviu falar em legislação na área de alimentos. Dos 34,8\% que já ouviram falar, apenas $8(34,8 \%)$ relataram ter acesso a elas, tendo sido referidas as seguintes fontes: Sindicato dos comerciantes e Procom, além de alguns terem citado o emprego anterior. 95,5\% dos proprietários nunca foram vistoriados pela vigilância sanitária. As respostas afirmativas foram três, uma delas afirmou já ter sido vistoriada 5 a 6 vezes, outro, 2 vezes e uma comerciante relatou ter sido vistoriada há dois anos.

Sobre análise dos alimentos (questões 26), 36,9\% dos entrevistados não sabe para que serve análise de alimentos. Para os que responderam afirmativamente, o gráfico 15 ilustra a finalidade das análises de alimentos:
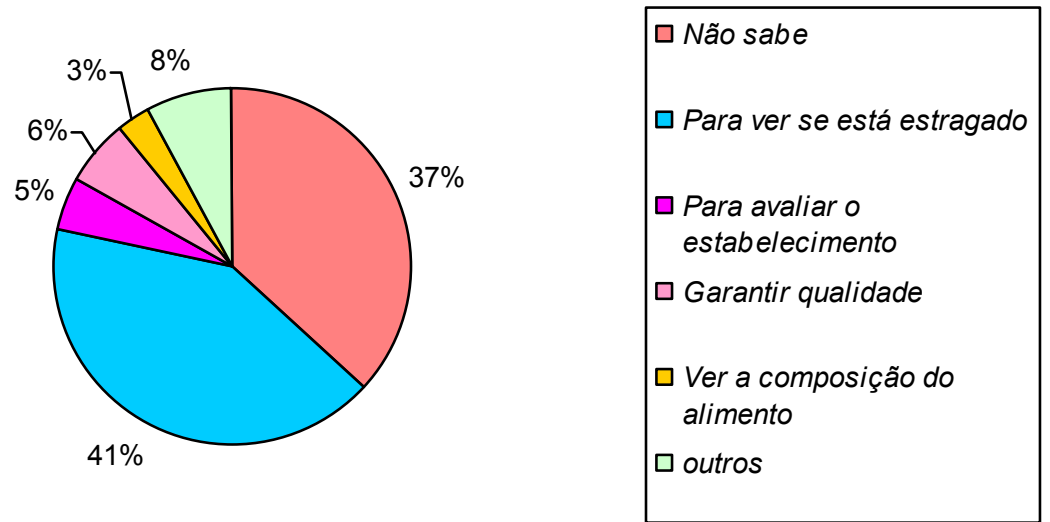

Gráfico 15- Opinião dos comerciantes da Comunidade São Remo sobre para o que serve as análises realizadas nos alimentos. São Paulo, 2001. 
Os entrevistados foram questionados se desejavam realizar análise de algum alimento (questão 27). Vinte e sete pessoas (52,9\% dos que responderam à pergunta), gostariam e autorizaram a análise de seus produtos inclusive alguns sugeriram alimentos para serem analisados. Como a colheita de amostra foi feita após as entrevistas, esta pergunta foi feita apenas para sondar se os comerciantes autorizariam este procedimento. Apesar do grande número de respostas negativas, ao retornar ao local, na fase de colheita de amostra, muitos comerciante acabaram por ceder a mesma para a pesquisa. Segundo o MANUAL de elemento de apoio para o sistema APPCC, (2001), a análise microbiológica é de fundamental importância na verificação da eficácia do Plano APCC e na avaliação das condições higiênico-sanitárias e das Boas Práticas nos estabelecimentos. Entretanto, é um recurso oneroso e que não se justifica por si só, sendo mais importante o controle higiênico-sanitário em todas as etapas e produção, com garantia de um produto final de qualidade. 


\subsection{ENTREVISTAS COM A POPULAÇÃO DA COMUNIDADE SÃO REMO}

Foram entrevistados 240 pessoas de diferentes domicílios e ambos os sexos, sendo aproximadamente $24,0 \%$ do total de domicílios.

Caracterização dos entrevistados

Do total de entrevistados, $214(89,2 \%)$ eram do sexo feminino contra apenas 26 entrevistados $(10,8 \%)$ do sexo masculino. Nota-se a inversão com relação aos comerciantes. No caso em questão, predominam pessoas do sexo feminino, responsáveis pela casa e pela manipulação dos alimentos. Com relação a idade, 74 entrevistados tinham idade entre 20 e 30 anos; 33, menos de 20 anos; 55, entre 30 e 40 anos; 43 entre 40 e 50 anos e 35 com mais de 50 anos. Predominam as mulheres jovens, entre 20 e 40 anos.(gráfico 16). Em pesquisa realizada em 1993 na mesma Comunidade, por (OLIVEIRA et al, 1998), a média de idade das mulheres entrevistadas era de 37 anos, estando dentro da faixa etária predominante neste estudo.

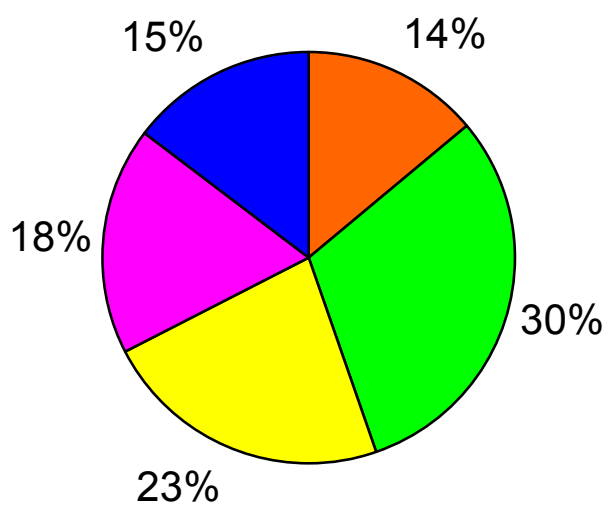

$\square$ Menor de 20 anos $\square$ Entre 20 e 30 anos $\square$ Entre 30 e 40 anos $\square$ Entre 40 e 50 anos

$\square$ Maior de 50 anos

Gráfico 16- Caracterização dos moradores da Comunidade São Remo quanto à idade. São Paulo, 2001. 
Quanto ao grau de instrução, temos 29 pessoas (12,1\%) que não estudaram, 160 (66,7\%) tem o ensino fundamental (completo ou não), 49 (20,4\%) cursaram ou estão cursando o ensino médio e uma pessoa tem ensino superior (Gráfico 17).

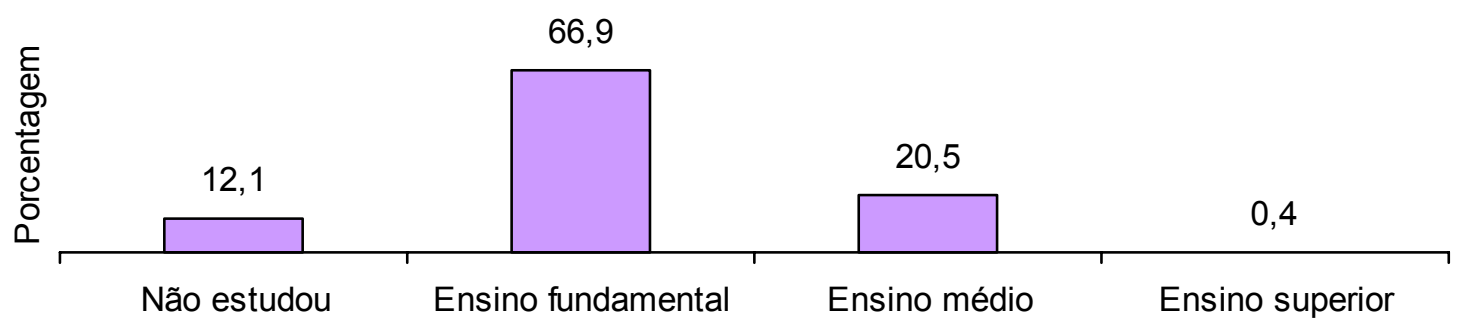

Gráfico 17- Grau de instrução da população entrevistados na Comunidade São Remo, São Paulo, 2001.

O gráfico 18 refere-se à ocupação dos entrevistados. Percebemos que a maioria das pessoas trabalha e alguns têm trabalho relacionado com a área de alimentos. Foram encontradas empregadas domésticas que relataram preparar a refeição no local onde trabalham. Ainda no trabalho de Oliveira, (1998), foram entrevistadas 4 donas de casa, equivalendo a cerca de $36,3 \%$ e a mesma porcentagem de pessoas trabalhando no setor informal, com vendas, costura ou serviço de manicure. Foram encontrados casos de desemprego e de famílias que mantinham algum tipo de comércio dentro da Comunidade.

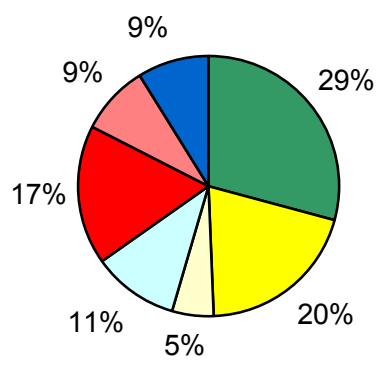

$\square$ Dona de casa
$\square$ Empregada doméstica, babá
$\square$ Estudante
$\square$ Desempregado, aposentado
$\square$ Funcionário da USP
$\square$ Emprego relacionado à área de
alimentos
$\square$ Autônomo

Gráfico 18- Ocupação dos entrevistados na Comunidade São Remo. São Paulo, 2001. 
Caracterização dos domicílios

Com relação ao número de moradores por domicílios, observamos que em 151 residências havia menos de quatro moradores, e em 89, mais de 4 moradores (questão $\mathrm{n}^{\mathrm{o}}$ 01). Dos que responderam a pergunta adequadamente, observamos que em 59 domicílios não há crianças (considerando crianças até 15 anos de idade); em 132 há até 4 crianças e em apenas 7 há mais de 4 crianças. Considerando o total de pessoas envolvidas inclusive indiretamente na entrevista, temos 1035 pessoas, cerca de 550 adultos e 300 crianças (muitos não informaram a idade dos moradores). A questão 2 procurava identificar quem era o responsável pelo preparo dos alimentos na casa. Dos 240 entrevistados, $159(66,3 \%)$ realizavam essa tarefa, em 52 (21,7\%) domicílios essa tarefa é dividida com uma ou mais pessoas, em 25 é realizada por outra pessoa, que não é o entrevistado.

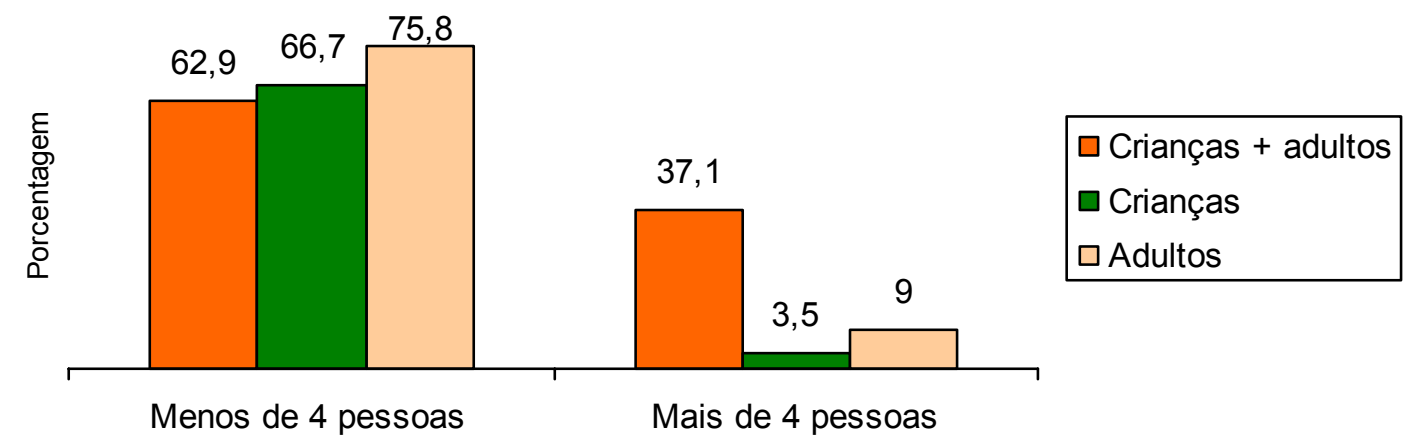

Gráfico 19- Número de pessoas que residem nos domicílios entrevistados da Comunidade São Remo, São Paulo, 2001.

Em $145(60,4 \%)$ domicílios os alimentos são preparados para menos de 4 pessoas (em geral para o número de moradores da casa), e em 94 (39,2\%) para mais de 4 pessoas (questão $\mathrm{n}^{\mathrm{o}}$ 03). Com as informações acima é possível observar o número de pessoas que dependem de uma boa conduta de higiene do cozinheiro a fim de garantir sua segurança alimentar. A quantidade de crianças é um número importante, uma vez 
que elas são mais suscetíveis às toxinfecções alimentares, além dos idosos, gestantes, pacientes com diversos problemas de saúde e imunossuprimidos (SHEWMAKE, 1998).

Caracterização dos alimentos consumidos

Os alimentos mais freqüentemente preparados são arroz e feijão $(94,2 \%)$, carne (73,3\%), salada (46,3\%) (questão nº 05). Segundo Oliveira, 1998, na Favela São Remo, o prato principal é composto pelo arroz e feijão, acompanhados de carne bovina ou frango, salada de alface ou tomate, totalizando cerca de $82 \%$ das entrevistadas.

Os alimentos são preparados todos os dias em 176 domicílios (73,3\%), contra $52(21,7 \%)$ em dias alternados (questão 4). Sendo assim, deverá haver uma conduta adequada para aproveitar as sobras de alimentos, basicamente guardando os mesmos imediatamente em geladeira ou após resfriamento rápido e reaquecendo até $74{ }^{\circ} \mathrm{C}$ no interior do alimento para o consumo (Portaria CVS 06/99). Esses procedimentos impedem a exagerada multiplicação bacteriana (que ocorre livremente em temperatura ambiente) e a provável produção de toxinas. O calor consegue eliminar a maioria das bactérias, mas não elimina esporos (formas de resistência) e toxinas, por isso a manutenção dos alimentos em refrigeração é importante.

A questão 6 refere-se ao local de aquisição dos alimentos (gráfico 20). As matérias primas são adquiridas em supermercados ou mercados (85\%); 14 (5,8\%) recebem cesta básica Com relação aos produtos de origem animal (questão 7), a carne é adquirida em açougues (94 respostas), em mercados e supermercados (153) e 33 adquirindo em outros locais, sendo os mais citados as peixarias e vendedores ambulantes. Em alguns questionários foi possível definir se os estabelecimentos citados pertenciam ou não à São Remo. Quando perguntados com relação a isso, alguns 
relataram nunca adquirirem seus produtos na comunidade, enquanto outros compram a maioria dos produtos nos locais mais próximos e também na própria comunidade. Quanto ao leite, 21 entrevistados adquirem em padarias, 183 em mercados e supermercados, 15 em pontos de distribuição gratuita localizados no interior da comunidade e 19 em outros locais, como o programa leve leite.

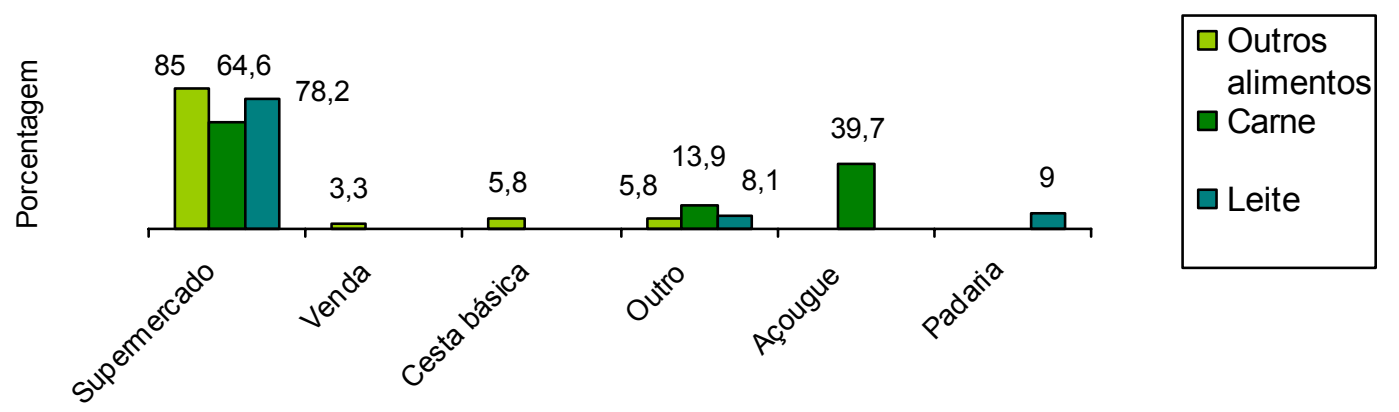

Gráfico 20- Local onde a população entrevistada da Comunidade São Remo adquire os alimentos. São Paulo, 2001.

A detecção do tipo de estabelecimento fornecedor da matéria prima que os moradores da São Remo consomem é importante para avaliarmos o papel do comércio da comunidade na dinâmica dos alimentos ali circulantes e o número de pessoas suscetíveis à boa manipulação e armazenamento correto de cada estabelecimento. De acordo com OLIVEIRA (1998), 91\% das moradoras da Comunidade São Remo entrevistadas adquire produtos em supermercados, 100\% em feiras, 64\% em Padarias, 91\% em açougues, $45,4 \%$ em bares e $54,5 \%$ em sacolões. No presente trabalho houve uma maior concentração da compra em supermercados, diminuindo a aquisição em açougues e padarias, provavelmente porque o primeiro, por comercializar uma quantidade maior de produtos, tem preços mais baixos. Muitos entrevistados citaram grandes estabelecimentos, como supermercados de rede e um grande açougue localizado em Pinheiros/SP. Os estabelecimentos maiores, via de regra procuram ter um 
procedimento de higiene mais rigoroso, sendo portanto uma boa fonte de aquisição de produtos.A questão 8 tratava da procura de informações presentes no rótulo dos alimentos pelos entrevistados (gráfico 21$) .169$ entrevistados (70,4\%) costumam ler o rótulo dos produtos quando adquirem ou em casa. Comparando com os dados obtidos em pesquisa realizada em 2002 na Inglaterra (FOOD STANDARDS AGENCY, 2002), onde $82 \%$ dos entrevistados observavam o rótulo dos alimentos com alguma freqüência (ocasionalmente (22\%), freqüentemente (31\%) ou sempre(29\%), e nos E.U.A., onde $60 \%$ responderam afirmativmente, (BRHUN, 1997), nota-se que há certa uniformidade de respostas. Porém, quanto ao que é observado no rótulo, na pesquisa Inglesa, 66\% afirmaram atentar para a data de validade, $47 \%$ observam a quantidade de calorias, $36 \%$ procuram instruções sobre o preparo e/ou armazenamento, 37\% informações sobre a presença de aditivos (corantes e conservantes) e 24\% sobre o País de origem do produto. De todos estes, os de maior importância são a data de validade, a origem do produto (não tanto o País, mas a procedência e registro no órgão competente, quando necessário) e o modo de preparo e armazenamento, sendo que este último não foi mencionado por nenhum entrevistado deste trabalho. Este assunto deve ser abordado em projetos educativos voltados para a população uma vez que a inocuidade da refeição começa com a aquisição de matérias - primas de qualidade.
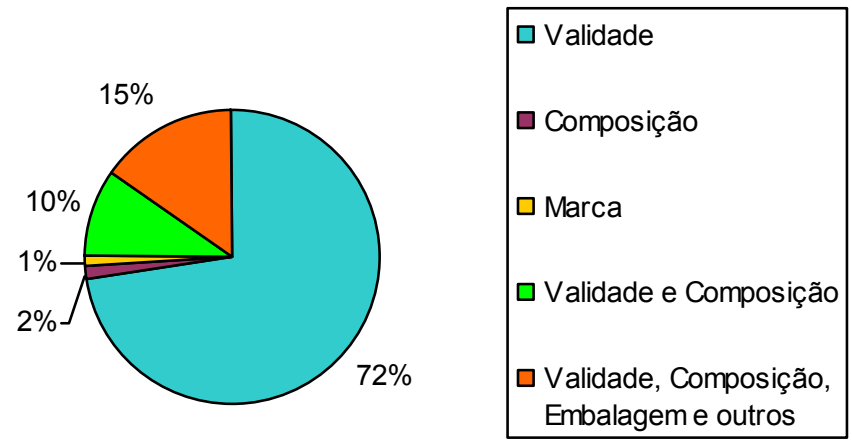

Gráfico 21- Características observadas no rótulo das mercadorias compradas pelos moradores da Comunidade São Remo, São Paulo, 2001. 
A questão 10 era sobre a duração dos alimentos adquiridos. Para 68,8\% dos entrevistados, a maioria dos alimentos é adquirida para durarem um mês; para 12,5\% uma semana; para 9,6\% quinze dias; para 2,5\% apenas um dia. No momento de responder, muitos entrevistados tinham respostas diferentes para os alimentos perecíveis e para os não perecíveis. Em geral, os produtos cárneos eram adquiridos com maior freqüência e em quantidades menores. Esta é uma característica bastante importante já que uma quantidade menor de produtos armazenados representa menor possibilidade de deterioração do alimento e também de manipulação desnecessária.

Relação com os alimentos, idéias sobre os alimentos

As questões a seguir serviram para introduzir a idéia de microrganismos em alimentos. No início, as perguntas não mencionavam bactérias e microrganismos, a fim de não influenciar a resposta dos entrevistados. É sempre um assunto bastante sutil falar sobre os conceitos contaminado e estragado (ou deteriorado). Os alimentos deteriorados apresentam, em geral, alterações organolépticas, ou seja, da cor, sabor, aspecto, cheiro e gosto, que permitem que o processo de deterioração seja detectado e alguma providência seja tomada. Já nos alimentos contaminados com as chamadas bactérias patogênicas, nada disso pode ser detectado, e portanto, fica difícil acreditar que um alimento com características organolépticas normais possa oferecer risco à saúde.

Com relação à questão 9, sobre a ocorrência de devolução ou inutilização de alimentos adquiridos pelo entrevistado, $143(59,6 \%)$ pessoas nunca tiveram que desprezar (jogar fora ou trocar) algum alimento. Das 97 (40,4\%) que já tomaram essa atitude, os produtos desprezados foram os seguintes (Gráfico 22): 


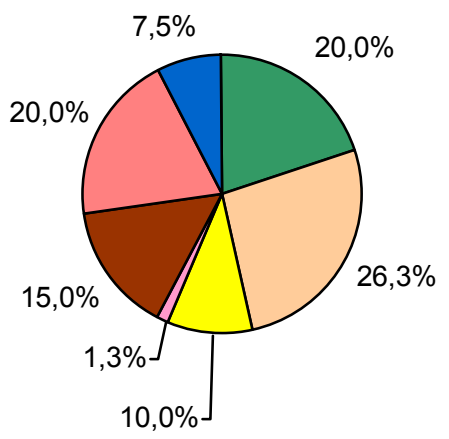

Carne e derivados e ovos

$\square$ Leite e derivados

$\square$ Refeições

$\square$ Vegetais

๑ Farináceos

$\square$ Enlatados e outros

industrializados

๑ Não lembra/outros

Gráfico 22- Alimentos que já foram desprezados por algum motivo pelos moradores da Comunidade São Remo, São Paulo, 2001.

O motivo alegado para tal atitude foi: Produto estava vencido $(38,2 \%)$, alimento estragado ou velho $(53,9 \%)$, embalagem danificada $(2,2 \%)$. Nota-se que os perecíveis como cárneos (crus ou cozidos) e lácteos foram os mais citados apenas confirmando a ação que os microrganismos deteriorantes tem sobre os alimentos com alta atividade de água e outras características intrínsecas que favorecem o crescimento bacteriano.

A maioria dos entrevistados não tem muita perda com alimentos estragados 89,2\%, (questão 11). As medidas tomadas para que isso não aconteça (questão 13) são: guardar os alimentos em geladeira ou freezer (122 respostas afirmativas ou 48,3\%); não comprar ou não preparar quantidades muito grandes de alimentos (100 respostas afirmativas, 42,4\% do total); 13 pessoas afirmaram não tomar nenhuma atitude para evitar que isso aconteça.

Ao serem indagados sobre a razão pela qual os alimentos estragam (questão 12), as respostas dadas constam no gráfico 23: 


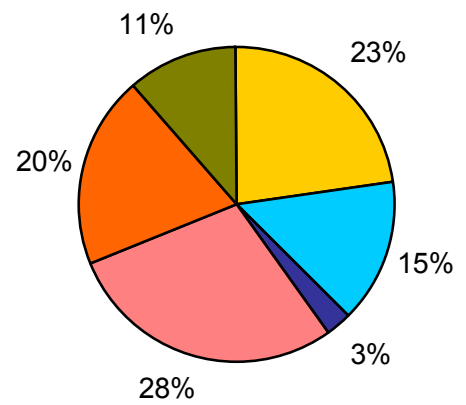

\begin{tabular}{|l|}
\hline Não Sabe \\
$\square$ Porque estão vencidos \\
$\square$ Tem má qualidade \\
$\square$ Ficam mal armazenados \\
$\square$ Porque ficam velhos \\
$\square$ Outros
\end{tabular}

Gráfico 23- Razões pelas quais os alimentos estragam, segundo os entrevistados na Comunidade São Remo, São Paulo, 2001.

Em nenhuma entrevista foi citada a ação dos microrganismos deteriorantes, mostrando a falta de associação feita entre microrganismos (seres invisíveis) e alterações visíveis nos alimentos.

Respondendo à questão 14, sobre se elas acham que alguns alimentos estragam mais rápido que outros, 208 pessoas $(87,8 \%)$ acham que sim, e dentre os alimentos que estragam mais rápido, os mais citados foram (Gráfico 24):

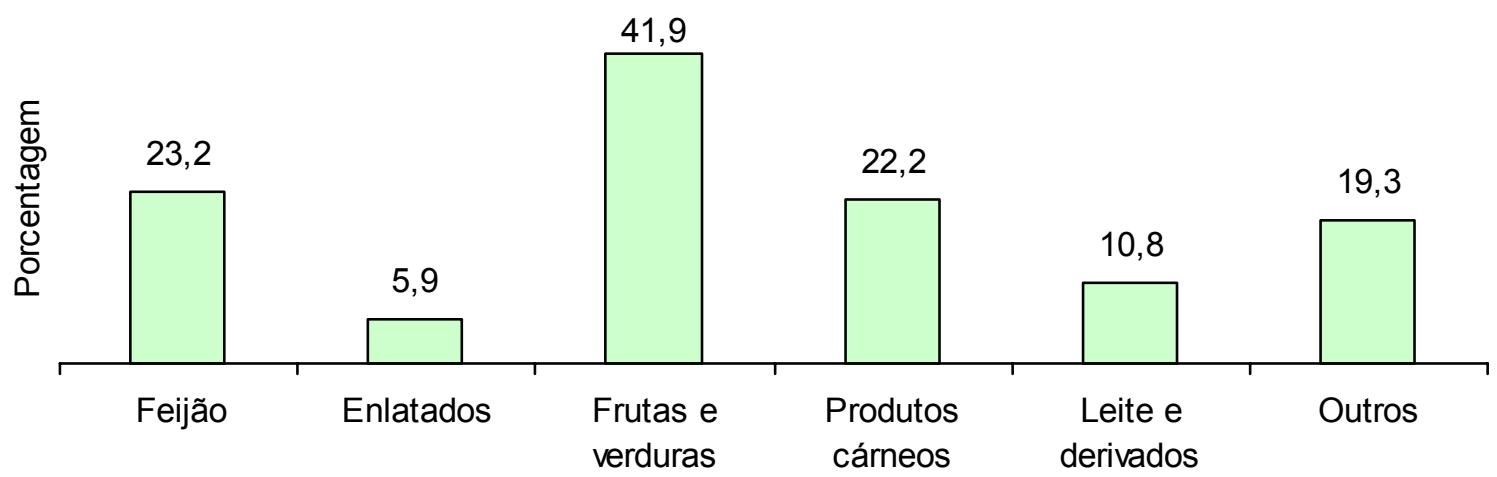

Gráfico 24- Alimentos que estragam mais rápido, segundo os entrevistados da Comunidade São Remo, São Paulo, 2001.

Com relação à razão pela qual alguns alimentos estragam mais rápido do que outros, as respostas obtidas encontram-se no gráfico 25 . 


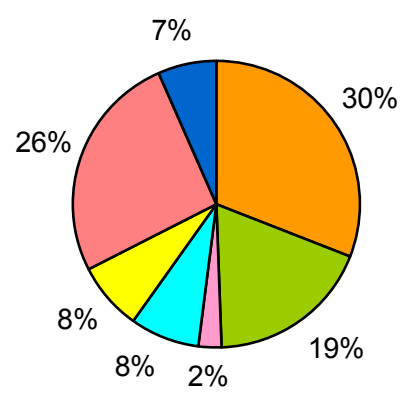

\begin{tabular}{|l|}
\hline$\square$ Porque ficam fora da geladeira \\
$\square$ Porque ficam velhos \\
$\square$ Por falta de cuidado \\
$\square$ Porque é um alimento frágil \\
$\square$ Por causa dos conservantes/Temperos \\
$\square$ Não sabe \\
$\square$ Outros
\end{tabular}

Gráfico 25- Razão pela qual alguns alimentos estragam mais rápido que outros, segundo a população entrevistada na Comunidade São Remo, São Paulo, 2001 .

As respostas foram sempre genéricas e superficiais. As pessoas percebem que os alimentos estragam e que alguns estragam mais rapidamente que outros. Dentre os exemplos citados, produtos com grande quantidade de água, como vegetais e ricos em nutrientes, como os de origem animal apareceram com maior frequência. Falta relacionar essas características (intrínsecas) com a ação das bactérias sobre elas. A visualização deste inimigo invisível contribuiria para elucidar uma série de "mistérios" que cercam os alimentos.

A questão 15, "O que você considera falta de higiene na hora de cozinhar?" era uma pergunta aberta (não estruturada), e as respostas foram categorizadas de forma a obter o que consta no Gráfico 26:

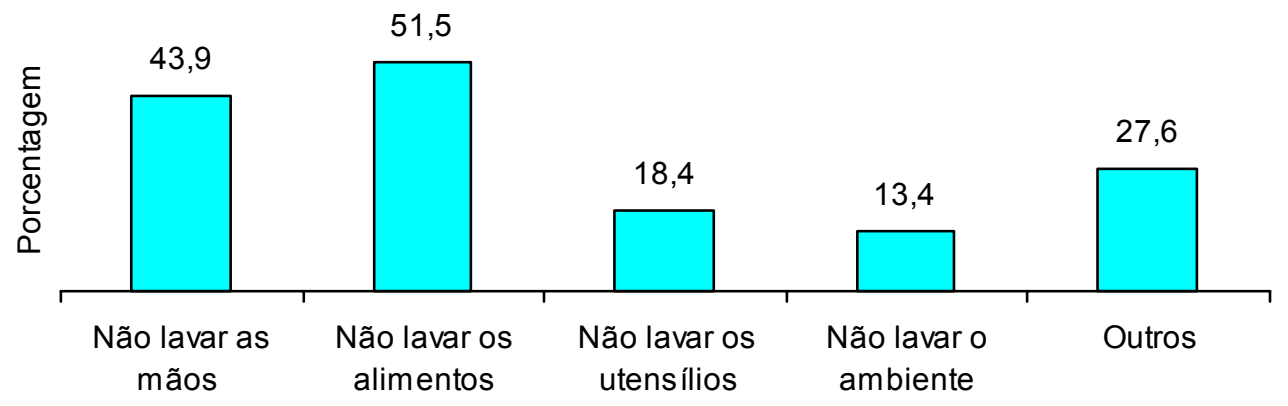

Gráfico 26- O que é considerado falta de higiene, na opinião dos moradores da Comunidade São Remo, São Paulo, 2001. 
As conseqüências que a falta de higiene pode trazer, na opinião dos entrevistados (questão 16), são : Contaminação, sujeira, bactérias, micróbios $(22,9 \%)$, doenças (alguns citaram doenças específicas) $(57,6 \%)$, comida estragada $(6,9 \%)$, atrair mosquitos, cair cabelo (4,8\%), entre outros. Aqui as bactérias aparecem, mostrando que elas não são um personagem completamente desconhecido. Além disso, as respostas são coerentes com a realidade, ou seja, falhas de higienização do manipulador, dos alimentos, equipamentos, ambiente e utensílios, aliada à manutenção dos alimentos em temperatura inadequada (fora de refrigeração), cozimento insuficiente e contaminação cruzada, pode levar à contaminação dos alimentos e todas as conseqüências relatadas.

Epidemiologia das toxinfecções alimentares na Comunidade São Remo

As questões relacionadas à ocorrência de intoxicação alimentar foram as de número 17 e 18. Dentre os 240 entrevistados, 99 (41,3\%) já apresentaram sintomatologia de intoxicação ou infecção após a ingestão de alimentos. Na pesquisa Inglesa mencionada anteriormente, FOOD STANDARDS AGENCY, (2002), 11\% dos entrevistados tinham apresentado sintomas gastrointestinais nos últimos doze meses. Os alimentos envolvidos nos episódios relatados neste trabalho constam no gráfico 27 :
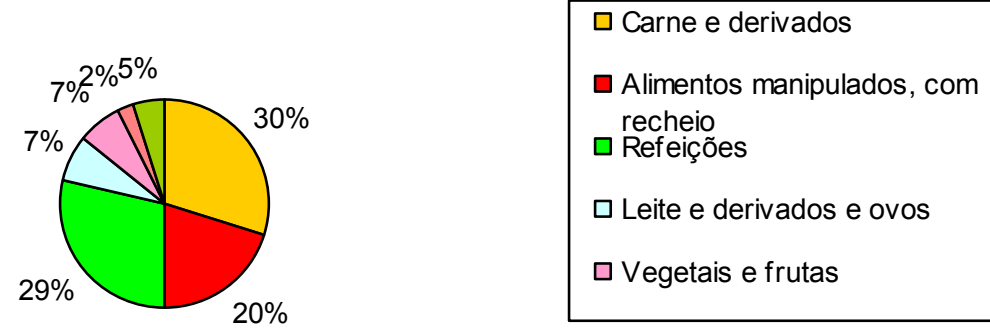

Gráfico 27- Alimentos suspeitos de terem causado intoxicação alimentar nos entrevistados da Comunidade São Remo, São Paulo, 2001. 
Sobre o item refeições, o mesmo referia-se a mais de um tipo de alimento, não sendo possível incriminar apenas um. Exemplos de alimentos elaborados com recheio são salgadinhos e sanduíches, incluindo o cachorro quente, citado oito das vinte vezes em que este item apareceu.

Segundo GERMANO (2001), os locais de alimentação coletiva como cantinas, refeitórios de indústrias e restaurantes ainda representam a maioria dos surtos notificados. Dos 198 surtos ocorridos no município de São Paulo nos anos de 1990 e 1991, 26,8\% ocorrerem em ambientes domiciliares, contra 27,8\% nos restaurantes, $9,1 \%$ em lanchonetes, 7,1\% em refeitórios, 4,5\% em rotisserias e 3,0\% em hospitais. Concordando com os dados do SIRVETA (Sistema de Informação Regional para a vigilância das doenças transmitidas por alimentos), coordenado pelo Instituto PanAmericano de Proteção de Alimentos e Zoonoses (INPPAZ), representando América Latina e Caribe notificou, no ano de 2000, 538 surtos de DTA, sendo que 196 deles ocorreram em domicílios, contra 39 em restaurantes, 93 em refeitórios e 48 em escolas, entre outros (OPAS/OMS, 2001).

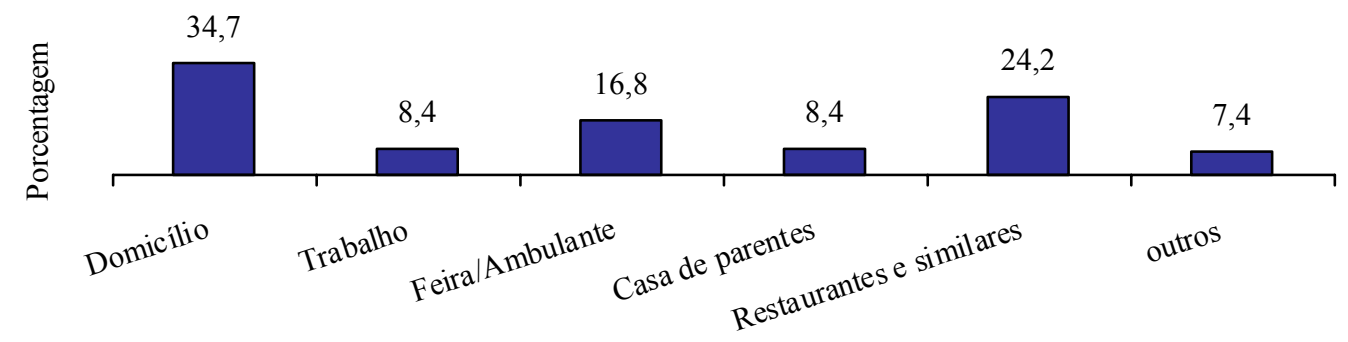

Gráfico 28- Locais onde os alimentos suspeitos de terem causado intoxicação alimentar foram ingeridos. São Paulo, 2001.

Nos dados obtidos pelo presente trabalho, a maioria das ocorrências se deu nos domicílios (Gráfico 28). De acordo com BRHUN (1997), grande parte dos consumidores acredita que os casos de toxinfecção alimentar em que estavam 
envolvidos foram causados por alimentos preparados em outros lugares que não sua própria casa. Entretanto, especialistas afirmam que casos esporádicos e pequenos surtos em casa ocorrem com muito mais freqüência do que os surtos reconhecidos.

Os sintomas relatados foram na maioria gastrointestinais clássicos, como diarréia, vômito, náusea, mal estar, dor de cabeça e dor no estômago. Outros sintomas, como reações alérgicas, foram citados (gráfico 29). Esses dados são muito importantes em uma investigação epidemiológica de surtos de intoxicação alimentar, pois de acordo com o alimento ingerido e os sintomas presentes (inclusive o tempo de aparecimento dos sintomas após a ingestão do alimento) é possível descobrir ou pelo menos sugerir o microrganismo responsável e qual procedimento foi o responsável pela sua aparição ali.

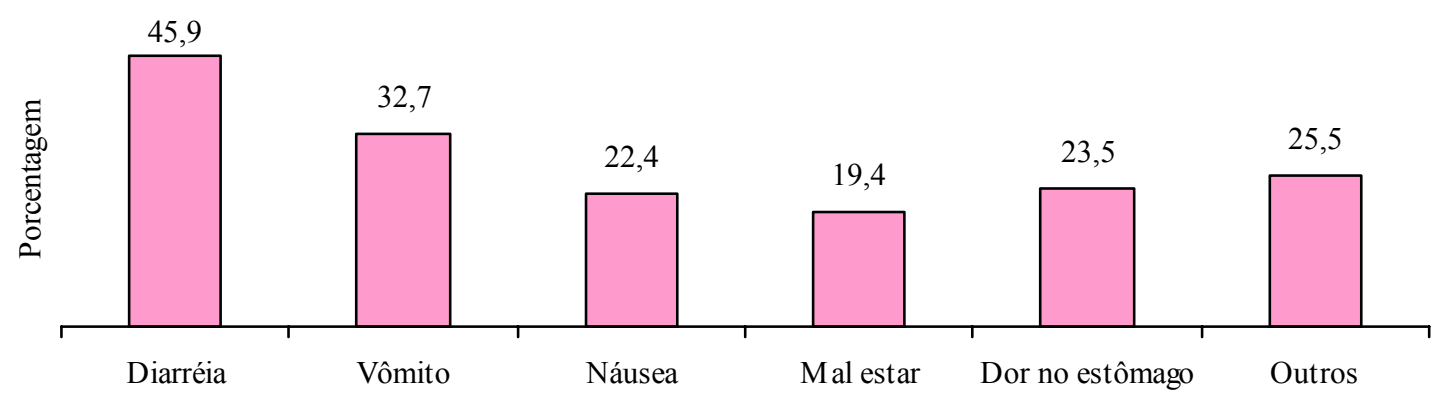

Gráfico 29- Sintomas apresentados após a ingestão de alimentos suspeitos. São Paulo, 2001.

Dos 99 acometidos, apenas $40(40,4 \%)$ foram ao médico (questão 18). Os $59,6 \%$ que não procuraram assistência médica alegaram ter melhorado $(23,1 \%)$, terem se auto-medicado $(69,2 \%)$ outras respostas $(7,7 \%)$. Este dado confirma a subnotificação dos casos de intoxicação. Menos da metade procurou o médico e destes, podemos supor que nem todos foram diagnosticados como intoxicação alimentar, e dos que foram não sabemos quantos destes casos foram notificados à vigilância epidemiológica. Um estudo realizado na Inglaterra mostrou que para cada caso detectado em laboratórios de 
Vigilância, existem mais 136 casos na comunidade (FORSYTHE, 2002). Segundo GERMANO (2001), estima-se que apenas 1 a $10 \%$ dos casos são computados por estatísticas oficiais.

Conhecimentos sobre Microbiologia geral e dos alimentos

A questão 19 perguntava se os entrevistados já tinham ouvido falar em micróbios ou bactérias e a questão 20 era sobre a primeira palavra que vinha à cabeça quando pensava nos microrganismos. Grande parte dos entrevistados já ouviu falar em micróbios e bactérias (230 pessoas, ou 95,8\%). A primeira palavra que vem à cabeça encontra-se no gráfico 30 .
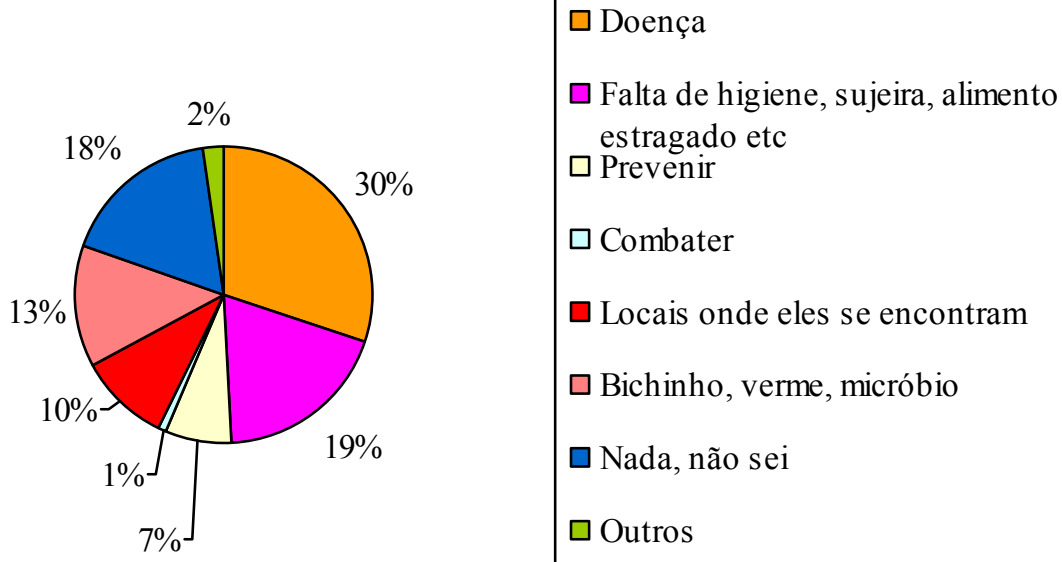

Gráfico 30- Palavras que vem à cabeça dos entrevistados quando pensam em bactérias. São Paulo, 2001.

Nesta questão, percebemos que muitos entrevistados não sabem exatamente o que são as bactérias, citando palavras genéricas ou parasitas visíveis a olho nu, como vermes, larva do mosquito da dengue, entre outros. É de fundamental importância, portanto, o esclarecimento desta questão em projetos educativos uma vez que as bactérias, dentre os demais microrganismos são o elemento-chave na contaminação dos 
alimentos e, portanto o principal inimigo (invisível) das pessoas envolvidas com os alimentos. Em 1255 surtos registrados no Paraná entre 1978 e 1996, 98,1\% dos que foi possível identificar o agente causador tiveram origem bacteriana. (GERMANO, 2001). Em outros trabalhos envolvendo entrevistas com a população, eram citados alguns microrgansimos e questionado se as pessoas conheciam estes patógenos e qual alimento estava relacionado a ele (ANGELILLO, 2001),onde revelou-se a falta de conhecimento com relação a maioria dos patógenos relacionados aos alimentos: apenas $36 \%$ conheciam todos os microrganismos citados pelos pesquisadores. Já segundo ALTEKRUSE (1995), um grande número de entrevistados conheciam a Salmonella spp e o Clostridium botulinum.

Com relação aos locais onde essas bactérias podem ser encontradas (questão 21), $94,9 \%$ citaram espontaneamente ou concordaram com a afirmação de que as bactérias nos seguintes locais (gráfico 31):

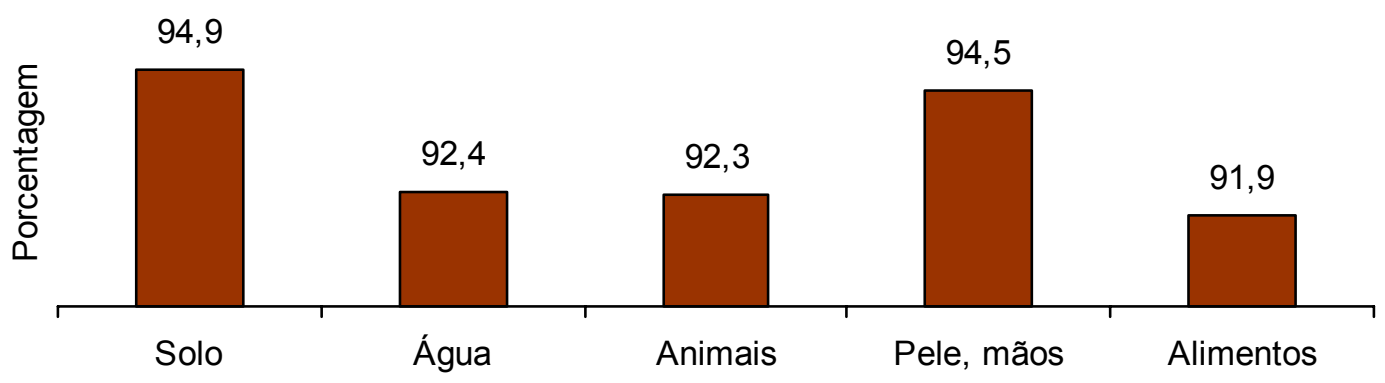

Gráfico 31- Locais onde as bactérias podem ser encontradas, segundo os moradores da Comunidade São Remo, São Paulo, 2001.

Outras respostas apareceram espontaneamente, tais como: banheiro $(14,5 \%)$, sujeira $(11 \%)$, ar $(11,4 \%)$, todos os lugares $(24,6 \%)$. Apesar da maioria das respostas serem corretas, alguns comentários que se seguiam às respostas mostravam a fragilidade deste conhecimento: "estão presentes na água parada”, "Na minha mão ou no meu cachorro não tem bactérias”. Para que as bactérias sejam destruídas (questão 
22), levando em conta o local onde podem ser encontradas, as respostas foram (gráfico 32):

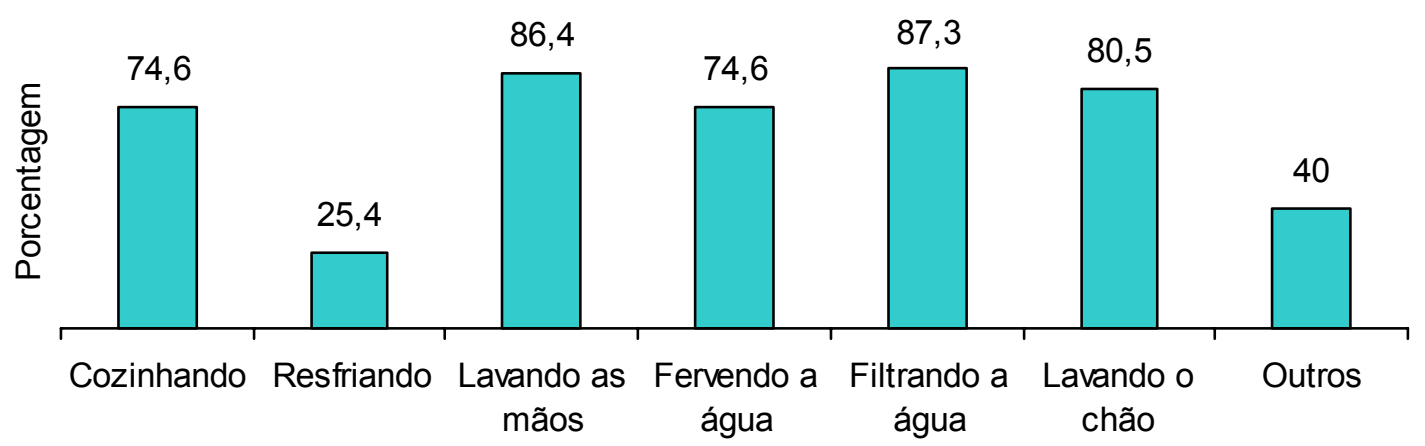

Gráfico 32- Formas de destruir as bactérias de acordo com os locais onde se encontram, segundo os moradores entrevistados da Comunidade São Remo, São Paulo, 2001.

Muitas pessoas citaram "lavar os alimentos", inclusive cárneos como uma forma de destruir as bactérias e outros citaram usar "remédio" para destruir as bactérias das mãos ou da pele, imaginando que as bactérias só estão presentes nas pessoas quando elas estão doentes. O resfriamento foi novamente citado como forma de destruir as bactérias. É necessário discutir este e outros conceitos com a população a fim de esclarecer a contribuição que cada um destes procedimentos descritos exerce sobre os alimentos. Em pesquisa realizada com donas de casa por WOODBURN (1997), métodos ineficazes como o resfriamento e congelamento também foram citados pelos entrevistados como forma de destruir algumas bactérias específicas.

Com relação à questão 23: "Você acha que os alimentos podem estar estragados e não apresentar nenhuma alteração visível ?’. Apesar de 74,7\% (177) das pessoas terem respondido que sim, ao serem perguntadas sobre a razão deste fenômeno, 40 $(23,7 \%)$ acabaram citando alguma alteração que o alimento iria apresentar, como cheiro ou gosto estranhos. Outras respostas para essa questão encontram-se no gráfico 33: 


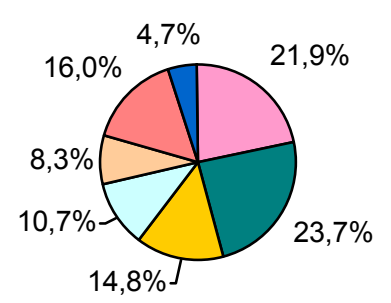

$\square$ Não sabe

๑ Tem alguma alteração no interior do alimento

$\square$ Não percebe que está estragado

$\square$ Pode ter bactéria

$\square$ Procedência ruim

$\square$ Alimento velho, mal conservado, estragado

$\square$ Produtos químicos, corante outros

Gráfico 33- Razões pelas quais o alimento pode estar estragado sem ter qualquer alteração organoléptica, na opinião dos moradores da Comunidade São Remo, São Paulo, 2001.

O conceito de contaminação também não está claro na cabeça das pessoas, pois era sempre mencionada alguma característica organoléptica alterada, sendo este fenômeno peculiar da ação dos microrganismos deteriorantes. É difícil conceber a presença de seres microscópicos no alimento e ainda sem dar qualquer sinal de sua presença ali.

Procedimentos na hora de cozinhar

Os principais cuidados que as pessoas tem na hora de cozinhar (questão 24) são, de acordo com as respostas: (161) cuidados com os alimentos, incluindo cozinhar bem, lavar bem e armazenar adequadamente; (101) higiene pessoal, considerando lavar as mãos e prender os cabelos; (56) cuidados com os utensílios e higiene do ambiente: 30 pessoas. Os valores em porcentagem encontram-se no gráfico 34. Nota-se de forma generalizada uma imprecisão nas respostas indicando que o tema não é por completo desconhecido, porém não se tem conhecimento preciso "do que" deve ser feito e o "porquê" deve-se adotar determinadas práticas durante a manipulação e preparação de 
alimentos. Um dos entrevistados relatou que deve ser feita a higienização dos utensílios previamente à sua utilização em tipos diferentes de alimentos. Apesar de saber que esta é uma prática correta, o indivíduo não soube explicar o porquê de tal conduta, que é essencial para evitar a contaminação cruzada entre os alimentos.

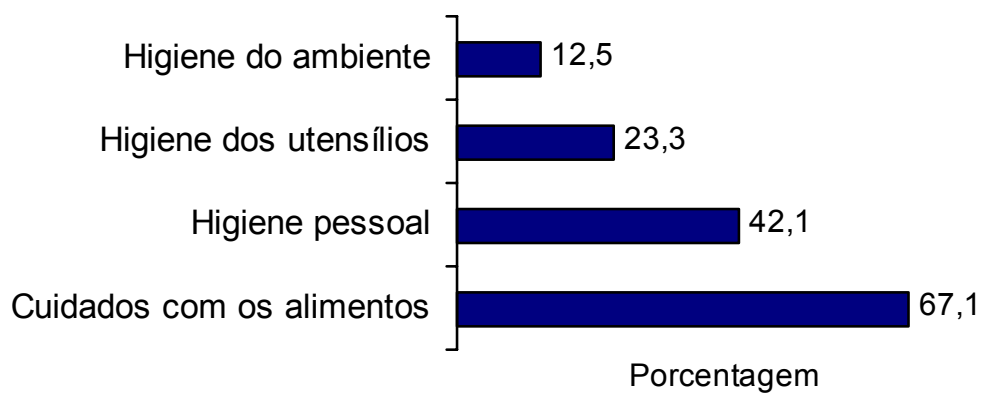

Gráfico 34- Principais cuidados que os entrevistados tem na hora de cozinhar. São Paulo, 2001.

A questão 25, citava três procedimentos realizados na cozinha e perguntava qual deles era o mais importante, sendo possível escolher mais de um item. 97,5\% dos entrevistados consideraram que lavar as mãos é a prática mais importante; $45 \%$ citaram o uso de avental e $87,1 \%$ disseram que prender o cabelo é importante. Ao comentar a baixa escolha do uso do avental, os entrevistados relatavam que o mesmo servia apenas para proteger a roupa, que era só tomar cuidado, ou que ao invés de usar avental, colocavam uma roupa limpa para manipular a refeição. $O$ fato das pessoas considerarem a higienização das mãos algo muito importante não significa que elas tenham este hábito. Segundo ALTEKRUSE, (1995), entrevista feita com consumidores mostrou que $86 \%$ das pessoas que preparam alimentos sabem que lavar as mãos reduz o risco de contaminação dos alimentos, mas apenas 66\% lavam as mãos após manipular carne crua ou frango. 
Doenças transmitidas pelos alimentos

Noventa e nove pessoas $(41,3 \%)$ conhecem alguma doença que pode ser transmitida através dos alimentos (questão 26). Foram citadas as seguintes: verminose (onde estão incluídas respostas como "verme da carne de porco" e outras relacionadas à carne de porco); diarréia, cólera, hepatite, giárdia etc; outras (como colesterol, gastrite, câncer e micose) (Gráfico 35). Aqui percebemos que o conhecimento é bastante difuso a respeito das doenças transmitidas pelos alimentos. Em primeiro lugar porque a carne de porco ainda é vista com vilã causadora de cisticercose quando este alimento é responsável pela transmissão da teníase (GERMANO, 2001). Não devemos, no entanto, desprezar esse conhecimento, e sim realizar um projeto educativo no sentido de aprimorá-lo, incluindo o importante papel dos vegetais crus e do homem no complexo teníase-cisticercose. As DTAs de origem bacteriana, foram citadas como diarréia, mas é importante conhecer os principais agentes envolvidos, em que tipo de alimento eles se encontram e se desenvolvem melhor e como fazer para evitar que eles cheguem até lá.
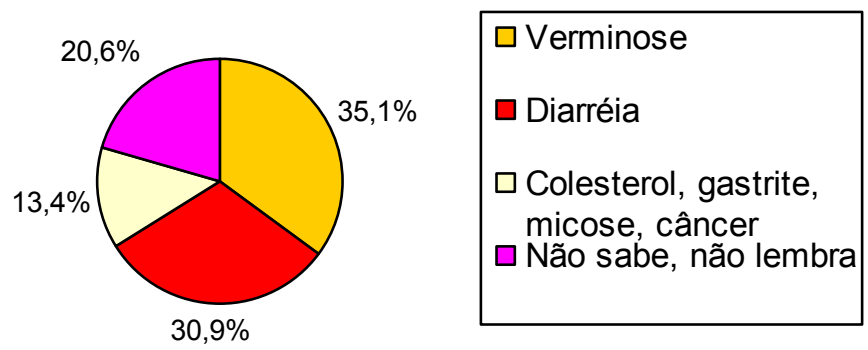

Gráfico 35- Doenças que podem ser transmitidas pelos alimentos, segundo a população da Comunidade São Remo, São Paulo, 2001.

De 92 pessoas que responderam a questão anterior, 50 (54,3\%) afirmam conhecer alguém que já apresentou a doença citada (questão 27). 85,6\% afirmaram saber como evitar e as formas de prevenção citadas foram as que constam no gráfico 
36. Como a cisticercose foi bastante citada, o procedimento de cozinhar bem ou ferver o alimento apareceu com maior freqüência, mostrando que a população está bem informada sobre a prevenção, mas não sabe bem o que está sendo prevenido com este procedimento. As práticas educativas devem preocupar-se em não apenas modoficar o hábito da população, mas fazê-las conscientes dessas mudanças e participantes ativas na diminuição das ocorrências de DTAs.

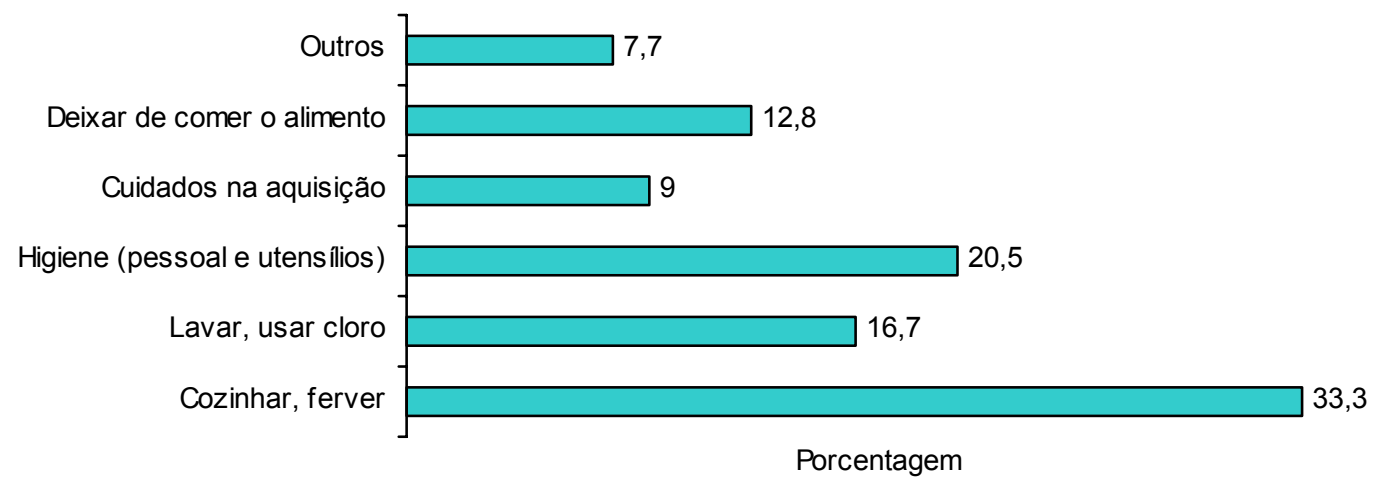

Gráfico 36- Como evitar as doenças transmitidas pelos alimentos de acordo com os moradores da Comunidade São Remo, São Paulo, 2001.

Quando perguntados sobre quais alimentos o entrevistado considerava mais perigoso (questão 29), as carnes bovina e suína foram citadas 101 vezes, sendo que a carne suína foi citada 82 vezes, demonstrando que a carne suína é vista de maneira cautelosa pelos consumidores desta comunidade (Gráfico 37).

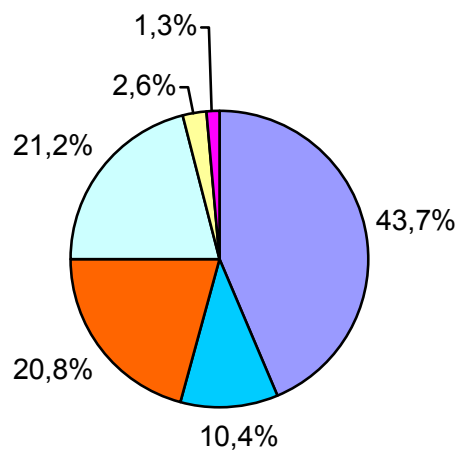
$\square$ Carne bovina e suína
$\square$ Outros produtos de origem animal, enlatados, refeições
$\square$ Vegetais
$\square$ Nenhum, não sabe
$\square$ Alimentos de rua, mal lavados
$\square$ Alimentos vencidos, estragados

Gráfico 37- Alimentos que os entrevistados consideram perigosos. São Paulo, 2001. 
Por que os alimentos citados eram considerados perigosos: por terem micróbios, sujeira ou produtos químicos: $36,4 \%$; porque são mal conservados ou porque estragam fácil e requerem cuidados: 11,1\%; porque provocam doenças: 29\%; porque não gosta, é muito "carregado": 16,7\%. Do ponto de vista higiênico-sanitário, os alimentos mais comumente envolvidos em surtos e com características intrínsecas mais favoráveis ao crescimento de microrganismos são os de origem animal (carne e derivados, leite e derivados e ovos) ou preparações contendo esses alimentos, tais como cremes com ovos ou leite (GERMANO, 2001). As razões pelas quais os alimentos foram citados como perigosos estão muito confusas, mas algumas mencionam a conservação inadequada e a contaminação de origem do alimento. Este tema deve ser desenvolvido em projetos educativos a partir deste ponto.

A questão 30 , a respeito da função da geladeira, foi feita a fim de detectar a importância dada pelo entrevistado a esse eletrodoméstico, uma vez que a conservação dos alimentos deve ser feita em geladeira, até sete graus ou acima de 65 graus, sendo, portanto um equipamento de suma importância para a obtenção de um alimento seguro. Além disso, por ser o local uma comunidade carente, a questão tinha por objetivo sondar se as pessoas possuem este aparelho, para que a prática de refrigerar os alimentos possa ser discutida sem obstáculos. As respostas encontradas foram: Conservar os alimentos: 92,9\%; guardar os alimentos: 22,1\%; gelar ou congelar os alimentos: $17,5 \%$. As respostas não revelaram nenhum aspecto inesperado, ou seja a maioria dos entrevistados reconhece a importância da geladeira com forma de conservar o alimento. Interessante seria discutir, em projetos posteriores, o papel da temperatura na multiplicação bacteriana, quando será possível entender o tipo de conservação do alimento que a geladeira promove. 
Relação do entrevistado com a comunidade e seus problemas

Apenas 13 pessoas, ou 5,4\% freqüentam a associação de moradores (questão 31). Entre outras formas de grupos que as pessoas freqüentam, catorze pessoas citaram igreja ou escola e 210 pessoas $(87,9 \%)$ não freqüenta nenhum tipo de grupo ou associação. As razões dadas por quem não freqüenta são: Falta de tempo: $44 \%$,falta de interesse: $31,9 \%$. O mesmo número de pessoas (31,9\%) afirmam nunca terem sido convidadas. A existência de grupos ou associações é comum nas Comunidades e representa uma forma bastante viável de acesso do pesquisador-educador à população. O fato de que poucas pessoas têm interesse em participar desses grupos, pode ter diversos significados, mas o importante é procurar abordar assuntos de interesse geral e de forma que as pessoas participem de forma ativa, escutando opiniões diversas e formando sua própria opinião a respeito dos assuntos. É com essa filosofia que um projeto educativo tem chance de dar certo, gerando ação e principalmente mudança de comportamento dos participantes.

Sobre o item c) da questão 31 , a respeito dos resultados que as discussões produzem, 90\% (dezoito pessoas) dos freqüentadores da associação ou outros grupos afirmaram que as discussões realizadas entre o grupo produzem resultados, citando exemplos de melhorias das ruas, conquistadas pela comunidade. Isso mostra que as pessoas que se reúnem para discutir, quando possuem um interesse comum, conseguem chegar a conclusões e promover mudanças em sua comunidade.

Com relação aos problemas existentes na Comunidade (questão 32, tabela 6), os mais citados foram com relação ao local (falta de creche, esgoto, presença de lixo), às pessoas (falta de educação e falta de higiene) e à situação (pobreza, miséria, desemprego, drogas, violência). 
Tabela 6- Principais problemas existentes na Comunidade São Remo segundo os moradores. São Paulo, 2001

\begin{tabular}{c|c|c}
\hline PROBLEMA CITADO & FREQUÊNCIA & PORCENTAGEM \\
\hline \hline $\begin{array}{c}\text { Relacionado às pessoas } \\
\text { (educação, higiene) }\end{array}$ & 38 & 15,8 \\
Relacionado ao ambiente \\
(falta de creche, esgoto, lixo)
\end{tabular}

Foram citados problemas inerentes à condição de vida precária dos moradores, como falta de rede de esgoto e coleta de lixo. Estes problemas também estão relacionados com a higiene e proteção dos alimentos. Assim, seria natural que uma discussão visando solucionar ou contornar estes problemas enfocasse a higiene dos alimentos. As soluções citadas, referentes ainda a questão 32, encontram-se na tabela 7:

Tabela 7- Soluções apontadas pelos moradores para os problemas existentes na Comunidade São Remo. São Paulo, 2001

\section{SOLUÇÃO CITADA}

FREQUÊNCIA PORCENTAGEM

\begin{tabular}{ccc}
\hline Prefeitura, presidente da Associação de & 21 & 8,8 \\
moradores & & \\
Participar, colaborar, conscientizar & 35 & 14,6 \\
Melhorias & 22 & 9,2 \\
Cada um cuida do que é seu & 12 & 5,0 \\
Educação, orientação, policiamento etc & 22 & 9,2 \\
Não sabe, não tem & 21 & 8,8 \\
Não respondeu & 133 & 44,6 \\
\hline Total & 240 & 100 \\
\hline
\end{tabular}

A questão foi categorizada de forma a agrupar respostas que citavam: a solução sendo trazida por uma pessoa de fora; a solução sendo fruto da participação e colaboração de toda a Comunidade; a solução vista como algo individual, ou seja, cada um cuidando dos seus próprios problemas e por fim, a citação do objeto que seria a 
solução, sem mencionar como isso seria alcançado, como por exemplo a construção de creches para solucionar o problema da falta de creches. Cerca de $25 \%$ das pessoas que responderam a essa pergunta citaram a participação e colaboração da Comunidade como uma forma de solucionar os problemas, mas, somando as outras respostas, percebemos que a maioria das pessoas tende a transferir a solução dos problemas para terceiros. Isso mostra um certo distanciamento e uma falta de comprometimento com as causas, ao mesmo tempo evidencia que a comunidade não tem noção do seu poder para solucionar problemas, inclusive acionando o poder público quando se juntam em grupos e discutem os assuntos. É de grande importância, portanto, a existência de uma associação de moradores na comunidade, e a mesma deve inserir todos os cidadãos e deve representar a opinião da comunidade como um todo e lutar pelas prioridades apontadas pela mesma. Para isso é fundamental que ocorram reuniões e discussões, que devem ser conduzidas de modo a ouvir e discutir as opiniões dadas por todas as pessoas.

Meios de comunicação utilizados, interesse em projetos educativos, sugestões para intervenção educativa:

Os meios de comunicação são um importante aliado na disseminação da informação e, portanto é importante saber com quais deles teremos um bom alcance da população-alvo. Os meios utilizados pelos entrevistados para obter informação (questão 33) são o que mostra o gráfico 38: 


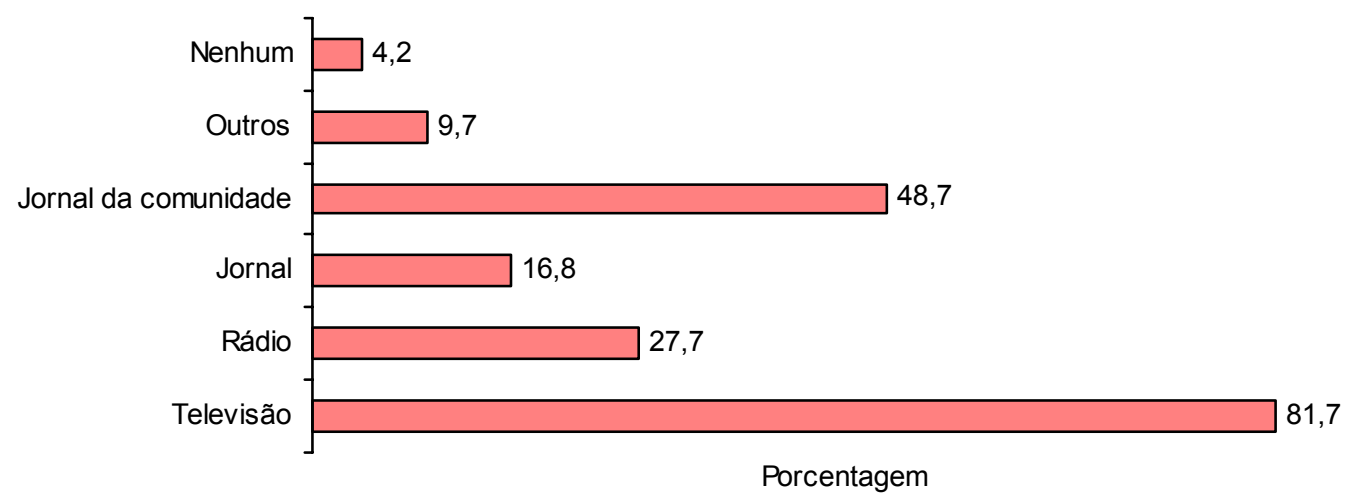

Gráfico 38- Veículos de comunicação utilizados pelos entrevistados para obter informação, na Comunidade São Remo, São Paulo, 2001.

Os meios incluídos na categoria outros foram Internet e "diálogos". Os jornais citados foram os de grande circulação, como O Estado de São Paulo, Folha de São Paulo, entre outros. A televisão representa o veículo mais difundido na Comunidade. Percebe-se o grande poder da televisão como disseminadora de informação. Devemos considerar a grande importância deste veículo ns dias atuais, considerar o poder de manipulação que tem este veículo e colocá-lo como nosso aliado no processo de educação. Isto requer educação da população no sentido de lançar um olhar crítico a respeito do que é visto e ouvido, não considerando tudo como verdade absoluta. Uma discussão mais aprofundada sobre o assunto pode ser encontrada em SOARES (1996), Que comenta que o 'homem audiovisual' ainda não faz um verdadeiro ato de reflexão, está apenas no estágio de um sincretismo e precisa romper com a fé originada da percepção e adotar a respeito dela uma atitude crítica: reflexão (conceituação, apropriação, julgamento crítico). Com relação ao Jornal da Comunidade, que é elaborado por estudantes do curso de jornalismo da Escola de Comunicação e Artes ECA-USP, este é lido por quase $50 \%$ das pessoas podendo ser uma ferramenta importante para difundir as atividades referentes à comunidade, principalmente devido à facilidade de acesso por parte dos pesquisadores e dos próprios moradores. 
Do total de entrevistados, $77,9 \%$ afirmaram que gostariam de saber mais sobre a higiene de alimentos (questão 34) e 52,6\% afirmaram saber qual era o profissional indicado para falar sobre esse assunto (questão 35), sendo o mais citado a nutricionista, com $41,2 \%$ das respostas. Mais uma vez constata-se a falta de conhecimento a respeito da atuação do médico veterinário nesta área. Por outro lado podemos nos aliar aos outros profissionais citados uma vez que há confiança no que é dito por eles.

Segue abaixo uma lista das dúvidas citadas pelos entrevistados que desejam saber mais sobre a higiene e conservação dos alimentos (tabela 8).

Tabela 8 - Dúvidas apontadas pelos moradores sobre a questão dos alimentos. São Remo, 2001.

DÚVIDAS SOBRE O ASSUNTO FREQÜÊNCIA

Alimentos saudáveis Alimentos orgânicos 4

Aprender pratos diferentes, receitas 2

"Esse negócio da carne de porco"

Sobre produtos embalados

Água

4

Sobre validade, se faz mal comer alimentos

vencidos

O que é bactéria?

1

$\mathrm{O}$ que são radicais livres?

1

Sobre as frutas e verduras (agrotóxicos, como

conservar, por que tem bichos etc)

Formas de conservação/ cuidados

Sobre as novidades

O que é mais perigoso, que tem mais

contaminação, alimentos que causam doenças, como

evitar.

O que acontece com os alimentos, por que estragam/ por que estragam tão rápido?

\section{Limpeza}

Como fazer o melhor processamento dos alimentos?

Como manter vitaminas após cozinhar

"Por que os meus filhos são muito magros?".

Produtos para limpeza dos alimentos

Relação da comida com nosso corpo

Como mastigar os alimentos 
DÚVIDAS SOBRE O ASSUNTO

(continuação)

Curiosidades sobre os alimentos (maçã, uva, leite, iogurte e feijão)

Carnes vindas do açougue não oferecem risco(são idôneas)?

Nutrição de crianças

Alimentos dietéticos para diabéticos

Porque algumas comidas dão enxaqueca?

Qualidade

\section{FREQUÊNCIA}

3

1

1

1

1

1

Como eliminar formigas e ratos?

Total 66

Em Food Standards Agency (2002), entrevistados ingleses citaram dúvidas a respeito da vaca louca (ou BSE); intoxicação alimentar; pesticidas, aditivos e antibióticos nos alimentos; alimentos saudáveis entre outros.

A questão 36 perguntava sobre a melhor forma de abordar o assunto higiene de alimentos, sendo os meios mais citados, os constantes no gráfico 39.

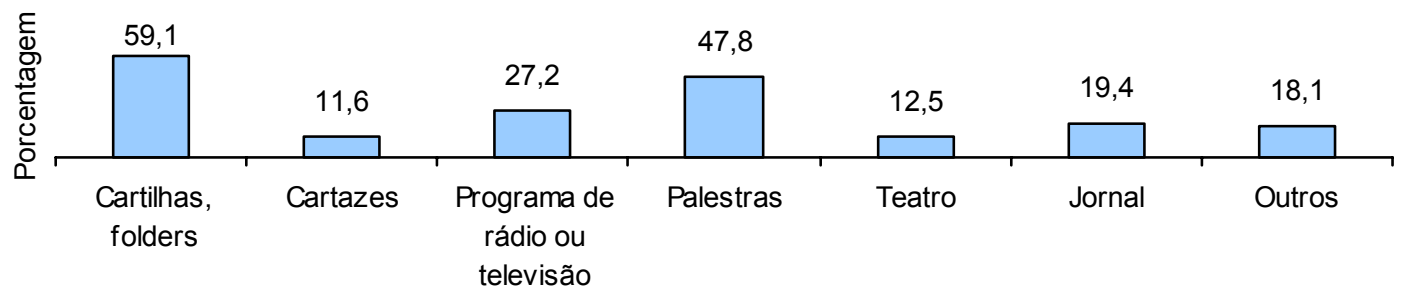

Gráfico 39- Melhor forma de aprofundar os conhecimentos sobre higiene de alimentos na Comunidade São Remo, São Paulo, 2001.

Como "outros", foram citados reuniões, ir de casa em casa etc. Essa opinião será muito valiosa na elaboração do projeto e, de alguma maneira, concorda com a nossa proposta, que pretende usar meios escritos, mas principalmente falados, para atingir inclusive as pessoas que não sabem ler. Dos meios falados, o rádio é de grande importância e as reuniões (não exatamente na forma de palestras) devem ser a essência de qualquer projeto educativo. 


\subsection{ANÁLISE MICROBIOLÓGICA DOS ALIMENTOS}

Os alimentos foram colhidos nos estabelecimentos constantes na figura 2:

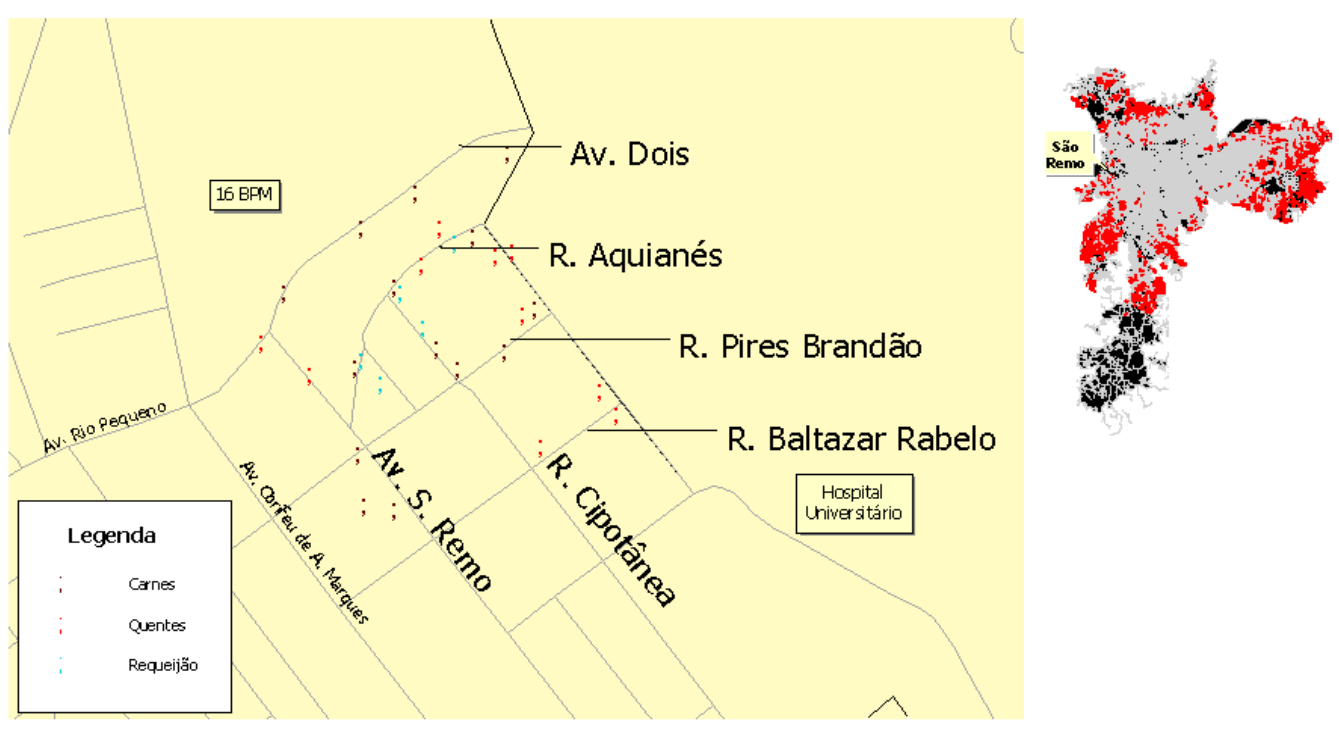

Figura 2- Estabelecimentos onde foram obtida amostras e os tipos de alimentos colhidos para análise microbiológica . São Paulo, 2001

Características do armazenamento:

No momento da colheita, foi possível observar algumas características do armazenamento e processamento dos alimentos, que constam nas tabelas 9 e 10. É importante salientar que algumas amostras foram colhidas no mesmo estabelecimento, e, portanto, o total de estabelecimentos com amostra coletada não é 40. 
Tabela 9- Características do armazenamento dos alimentos in natura nos estabelecimentos de alimentos da Comunidade São Remo. São Paulo, 2001

\begin{tabular}{ccccc}
\hline $\begin{array}{c}\text { No da } \\
\text { amostra }\end{array}$ & Alimento & $\begin{array}{c}\text { Tipo de } \\
\text { estabelecimento }\end{array}$ & Procedência & Refrigeração? \\
\hline \hline 1. & carne seca & Bar & SIF & Não \\
2. & carne seca & Bar & $\begin{array}{c}\text { Sem } \\
\text { embalagem }\end{array}$ & Não \\
& & & Sem rótulo & Não \\
3. & carne seca & "Casa do norte" & Não & Sim \\
4. & carne seca & Quitanda & visualizada & \\
& & & Sem rótulo & Não \\
5. & carne seca & Mercearia & Sem rótulo & Sim \\
6. & Requeijão & Mercado & SIF & Não \\
7. & Requeijão & Padaria & SIF & Não \\
8. & Requeijão & "Casa do norte" & SIF & Não \\
9. & Requeijão & Mercearia & Sem rótulo & Sim \\
10. & Requeijão & Bar & Sem rótulo & Não \\
11. & Lingüiça(paio) & Bar & Sem rótulo & Não \\
12. & Lingüiça(paio) & Mercearia & SIF & Sim \\
13. & Lingüiça fresca & Bar & SIF & Sim \\
14. & Lingüiça (paio) & Avícola & Sim \\
15. & Frango temp. & "Casa do norte" & Sem rótulo & Sim \\
16. & Frango fresco & Avícola & Sem rótulo & Não \\
17. & Frango temp. & Mercado & Sem rótulo & Sim \\
18. & Frango temp. & Bar & Sem rótulo & Sim \\
19. & Tilápia inteira & Peixaria & Sem rótulo & Congelado \\
20. & Corvina inteira & Peixaria & Sem rótulo & Não \\
21. & Bife (c. duro) & Mercado & Sem rótulo & Sim \\
22. & Braço (pedaço) & Açougue & Sem rótulo & Sim \\
23. & Braço (moído) & Açougue & Sem rótulo & Sim \\
24. & Carne moída & Mercado & Sem rótulo & Sim \\
25. & Bife (patinho) & Mercado & Sem rótulo & Não \\
\hline & & & &
\end{tabular}

Os locais onde estes alimentos estão sendo comercializados são permitidos pela legislação (Decreto Estadual 12.342/78), havendo exigências quanto à estrutura e dimensões obrigatórias para a atividade, com exceção das avícolas, que são proibidas desde 1978 pelo Decreto Estadual 12.342/78, artigos 463 e 464 onde consta que é proibida a comercialização de aves vivas e abatidas no mesmo local. A comercialização de frango temperado em bares e casas do norte também não são permitidas, e aos açougues, somente é possível comercializa-la quando o manipulador possui um certificado de treinamento para carne temperada. Com relação às condições em que eram armazenadas, percebemos irregularidades em $24 \%$ dos estabelecimentos, a saber: 
na avícola, onde a ave era abatida, embalada e comercializada sem qualquer etapa que permitisse a diminuição da temperatura da carcaça; em uma peixaria, onde o produto foi encontrado congelado porém exposto à venda em recipiente aberto e em temperatura ambiente; em um açougue, no qual as peças eram retiradas da vitrine e deixadas em bancadas a temperatura ambiente e na maioria das amostras de queijo tipo requeijão do norte, que eram mantidas fora de refrigeração. A manutenção das matérias-primas em temperatura inadequada comprometem a qualidade do produto final representando risco ao consumidor. Com relação à origem dos produtos de origem animal, foram encontrados apenas 6 produtos $(24 \%)$ com embalagem e carimbo do Serviço de Inspeção Federal (SIF), que garante a qualidade do produto em questão. Não foi solicitado, no entanto notas fiscais referentes aos produtos sem embalagem, como cárneos e frango temperado, e portanto esse valor pode ser maior.

Tabela 10- Características do armazenamento dos alimentos prontos para o consumo nos estabelecimentos. São Paulo, 2001

\begin{tabular}{|c|c|c|c|c|}
\hline $\begin{array}{c}\mathrm{N} \circ \mathrm{da} \\
\text { amostra }\end{array}$ & Alimento & $\begin{array}{c}\text { Tipo de } \\
\text { estabelecimento }\end{array}$ & Preparação & $\begin{array}{c}\text { Forma de } \\
\text { conservação }\end{array}$ \\
\hline 26. & Pastel de carne & Ambulante & Outro local & $\begin{array}{l}\text { Temperatura } \\
\text { ambiente }\end{array}$ \\
\hline 27. & Pastel de Bauru* & Ambulante & Outro local, & $\begin{array}{l}\text { Temperatura } \\
\text { ambiente }\end{array}$ \\
\hline 28. & Pastel de carne & Padaria & No local & Geladeira** \\
\hline 29. & Pastel de Bauru* & Padaria & No local & Geladeira** \\
\hline 30 . & Pastel de frango & Ambulante & No local & Geladeira** \\
\hline 31. & Coxinha de frango & Bar & No local & Estufa \\
\hline 32. & Coxinha de frango & Bar & No local & Geladeira** \\
\hline 33. & Esfiha de carne & Bar & No local & Estufa \\
\hline 34. & Salgado de frango & Bar & No local & Estufa \\
\hline 35. & $\begin{array}{c}\text { Salgado de pres. e } \\
\text { queijo }\end{array}$ & Bar & No local & Estufa \\
\hline 36. & Cachorro quente & Bar & No local & Estufa \\
\hline 37. & Cachorro quente & Ambulante & No local & Banho-maria \\
\hline 38. & $\begin{array}{l}\text { Maionese de } \\
\text { legumes }\end{array}$ & Restaurante & No local & $\begin{array}{l}\text { Temperatura } \\
\text { ambiente }\end{array}$ \\
\hline 39. & $\begin{array}{l}\text { Carne seca } \\
\text { acebolada }\end{array}$ & Restaurante & No local & Banho-maria \\
\hline 40. & Bife acebolado & Restaurante & No local & Geladeira** \\
\hline
\end{tabular}

*Pastel de Bauru: recheio a base de queijo tipo mussarela e presunto ou apresuntado cozido.

**Frito sob pedido do cliente 
Com relação aos alimentos prontos para o consumo notou-se um maior número de irregularidades com relação aos in natura. $40 \%$ dos pastéis eram guardados em uma gaveta e deixados durante todo o dia em temperatura inadequada; $80 \%$ dos salgados como coxinha, esfiha e risoles eram mantidos em estufa que não conseguem manter sua temperatura acima de $65^{\circ}$, conforme exige a legislação (Portaria CVS 06/99) o mesmo vale para as amostra de cachorro quente armazenada da mesma forma. A maionese de legumes, produto muito manipulado e, portanto com risco de contaminação estava sendo mantido, juntamente com as outras saladas, em temperatura ambiente.

\section{Análise Microbiológica dos Alimentos}

Os resultados das análises realizadas encontram-se nas tabelas 11 a 14, separados pelo tipo de alimento. Os resultados da pesquisa de Staphylococcus foi apresentado como coagulase positiva e negativa pois obteve-se um grande número de amostras com crescimento em placa mas sem confirmação na coagulase e preferimos manter esses resultados para discuti-los. O resultado da enumeração de coliformes totais e fecais foi dado em numero mais provável por grama (NMP/g).

Tabela 11- Resultado das análises feitas em amostras de Carne Seca, São Paulo, 2001

\begin{tabular}{ccccc}
\hline Amostra & $\begin{array}{c}\text { C. totais } \\
(\mathbf{N M P / g )}\end{array}$ & $\begin{array}{c}\text { C. fecais } \\
(\mathbf{N M P} / \mathbf{g})\end{array}$ & $\begin{array}{c}\text { Staphylo coag. } \\
(+) \text { ou (-) }\end{array}$ & $\begin{array}{c}\text { Bolores e } \\
\text { leveduras (UFC) }\end{array}$ \\
\hline \hline 1. & $<3$ & $<3$ & $(-) 1,5 \times 10^{3}$ & $1,7 \times 10^{3}$ \\
2. & 9 & $<3$ & $(-) 9,4 \times 10^{2}$ & $4,7 \times 10^{2}$ \\
3. & 9 & $<3$ & $(-) 1,2 \times 10^{2}$ & $8,5 \times 10$ \\
4. & 9 & $<3$ & $(-) 7,5 \times 10$ & $4,5 \times 10$ \\
5. & $<3$ & $<3$ & $(-) 1,9 \times 10^{2}$ & $3,5 \times 10$ \\
\hline $\begin{array}{c}\text { Limites } \\
\text { estabelecidos pela } \\
\text { legislação }\end{array}$ & Não há & $10^{2}$ & $(+) 10^{3}$ & Não há \\
\hline
\end{tabular}


Tabela 12- Resultados das análises feitas em amostras de Requeijão do Norte, São Paulo, 2001

\begin{tabular}{cccc}
\hline Amostra & C. totais (NMP/g) & C. fecais (NMP/g) & $\begin{array}{c}\text { Staphylococcus } \\
\text { Coagulse (+)ou(-) }\end{array}$ \\
\hline \hline 6. & $1,1 \times 10^{4}$ & $9,310^{2}$ & $(-) 1,6 \times 10^{6}$ \\
7. & $<3$ & $<3$ & $(-) 8,5 \times 10^{6}$ \\
8. & $\geq 2,4 \times 10^{5}$ & $<3$ & $(-) 1,5 \times 10^{7}$ \\
9. & $\geq 2,4 \times 10^{5}$ & $9,3 \times 10^{2}$ & $(+) 5,0 \times 10^{4}$ \\
10. & $2,4 \times 10^{2}$ & $2,3 \times 10^{2}$ & $(-) 1,1 \times 10^{5}$ \\
\hline \hline $\begin{array}{c}\text { Limites } \\
\text { estabelecidos pela } \\
\text { legislação }\end{array}$ & Não há & $5 \times 10^{3}$ & $(+) 10^{3}$ \\
\hline
\end{tabular}

De acordo com a legislação RDC 12 de 2001, apenas uma amostra de Requeijão do Norte apresenta-se em desacordo, em virtude da presença em altas concentrações Staphylococcos coagulase positiva (Tabela 12). As demais amostras de Requeijão e as de carne seca (tabela 11), apesar de apresentarem altas contagens, foram negativas no teste da coagulase. É importante atentar para este alto número de amostras coagulase negativa. Quase 60\% das amostras submetidas a esta análise apresentaram resultado positivo sendo $43 \%$ delas com concentrações muito elevadas, acima de $10^{4}$ e $57 \%$ até $10^{3}$.Este dado é bastante importante uma vez que estudos mostram a existência de bactérias do gênero Staphylococcus com reação negativa no teste da coagulase produzindo toxinas e sendo incriminadas em surtos de intoxicação alimentar e também parece com freqüência como oportunista causando infecções hospitalares. Dessa forma, apesar da legislação não incluir limites para a presença destes microrganismos, o risco é grande e faz-se necessário a mudança nos protocolos de análise, realizando os testes complementares inclusive para as colônias coagulase negativa (MIWA, 2001). Convém comentar que a amostra positiva para Staphylococcus coagulse positiva era a única amostra de requeijão do norte fatiado. É possível que as condições gerais de higiene que envolvem a manipulação e fatiamento do produto tenham colaborado para aumentar a contaminação, uma vez que este equipamento permanece durante todo o dia 
com resíduos de diversos alimentos muito ricos em nutrientes e em temperatura ideal para a proliferação de bactérias.

Os valores encontrados na pesquisa de bolores e leveduras para as amostras de carne seca estão dentro dos padrões estabelecidos pela legislação. Esses microrganismos podem ser encontrados em alimentos com baixa atividade de água, como é o caso da carne seca e são indicativos de armazenamento e manipulação inadequada (MESA SESC, SEBRAE...). É importante adquirir este alimento de fornecedores idôneos, com fiscalização do serviço de inspeção federal (SIF) ou estadual e armazenar o produto em local fresco e arejado.

Tabela 13- Resultados da pesquisa de Coliformes totais e fecais (NMP/g) realizadas nas amostras dos demais alimentos in natura.São Paulo, 2001

\begin{tabular}{cccc}
\hline Número da amostra & Alimento & C.totais (NMP/g) & $\begin{array}{c}\text { C. fecais } \\
\text { (NMP/g) }\end{array}$ \\
\hline \hline 11. & Lingüiça tipo paio & $<3$ & $<3$ \\
12. & Lingüiça tipo paio & $4,6 \times 10^{2}$ & $<3$ \\
13. & Lingüiça fresca & $<3$ & $<3$ \\
14. & Lingüiça tipo paio & $<3$ & $<3$ \\
15. & Frango temperado & $2,4 \times 10^{2}$ & 9,0 \\
16. & Frango fresco & $4,6 \times 10^{3}$ & $4,6 \times 10^{3}$ \\
17. & (abatido) & & \\
18. & Frango temperado & $4,6 \times 10^{2}$ & $4,6 \times 10^{2}$ \\
19. & Frango temperado & $\geq 2,4 \times 10^{3}$ & $9,3 \times 10$ \\
20. & Corvina inteira & $<3$ & $<3$ \\
21. & Tilápia inteira & $4,3 \times 10$ & $2,3 \times 10$ \\
22. & Bife (coxão duro) & $1,5 \times 10$ & $<3$ \\
23. & Braço (pedaço) & 9,0 & 4,0 \\
24. & Braço moído & $2,4 \times 10^{4}$ & $2,4 \times 10^{2}$ \\
25. & Carne moída & $1,5 \times 10^{5}$ & $4,3 \times 10^{2}$ \\
\hline \hline & Bife (patinho) & $2,4 \times 10^{2}$ & $<3$ \\
\hline \hline Limites estabelecidos & Lingüiça tipo paio & & $10^{3}$ \\
pela legislação & Frango temperado & & $10^{4}$ \\
& Peixe congelado & Não há & $10^{2}$ \\
& Carne bovina & & Não há \\
\hline
\end{tabular}

Com relação à enumeração de coliformes totais, amostras de requeijão do Norte (tabela 12), frango temperado e carne moída (tabela 13), apresentaram valores de até 
$10^{5} \mathrm{NMP} / \mathrm{g}$, chegando a $10^{3} \mathrm{NMP} / \mathrm{g}$ para coliformes fecais. Esses valores, embora elevados não estão fora dos padrões especificados pela legislação. No caso da carne bovina, por exemplo, não há padrões mínimos estabelecidos para esses indicadores. Os alimentos in natura serão provavelmente submetidos a algum processamento térmico e devem atingir temperaturas acima de $74^{\circ}$, quando esses microrganismos serão inativados. Nas amostras 22 e 23, referentes ao mesmo produto, porém em diferentes apresentações (inteiro e moído), podemos notar o aumento significativo de contaminação entre uma e outra. O moedor aparece como única via de contaminação, já que o produto foi moído na hora.

Quanto às amostras pesquisadas para presença de Salmonella spp, não foi observado resultado positivo, tendo algumas mostrado crescimento até a etapa anterior (TSI), sendo negativas para o teste da soroaglutinação. O teste de soroaglutinação é um tanto subjetivo, pois depende da interpretação de que o está realizando. Outros métodos podem ser mais eficazes e confiáveis, como a série bioquímica, por exemplo.

Tabela 14- Resultado das análises realizadas em alimentos preparados, São Paulo, 2001

\begin{tabular}{ccccc}
\hline $\begin{array}{c}\text { Número da } \\
\text { amostra }\end{array}$ & Alimento & $\begin{array}{c}\text { C.totais } \\
(\text { NMP/g) }\end{array}$ & $\begin{array}{c}\text { C. fecais } \\
(\text { NMP/g) }\end{array}$ & $\begin{array}{c}\text { Staphylococcus } \\
\text { coag. (+) ou ( -) }\end{array}$ \\
\hline \hline 26. & Pastel de carne & $<3$ & $<3$ & Ausência \\
27. & Pastel de bauru & $<3$ & $<3$ & Ausência \\
28. & Pastel de carne & $<3$ & $<3$ & Ausência \\
29. & Pastel de Bauru & $<3$ & $<3$ & Ausência \\
30. & Pastel de frango & $<3$ & $<3$ & Ausência \\
31. & Coxinha de frango & $9,3 \times 10$ & $<3$ & $1,1 \times 10^{7}$ \\
32. & Coxinha de frango & $<3$ & $<3$ & $2,0 \times 10^{3}$ \\
33. & Esfiha de carne & $<3$ & $<3$ & Ausência \\
34. & Salgado de frango & $<3$ & $<3$ & Ausência \\
35. & Salgado de pres. e queijo & $<3$ & $<3$ & Ausência \\
36. & Cachorro quente & 4,0 & $<3$ & $2,7 \times 10^{2}$ \\
37. & Cachorro quente & $9,3 \times 10$ & $<3$ & $1,19 \times 10^{4}$ \\
38. & Maionese de legumes & $<3$ & $<3$ & $2,9 \times 10^{2}$ \\
39. & Carne seca acebolada & $<3$ & $<3$ & Ausência \\
\hline Limites & Bife acebolado & $<3$ & $<3$ & Ausência \\
estabelecidos & Pastel/Salgado/cachorro & Não há & $10^{2}$ & $10^{3}$ \\
pela legislação & quente & Não há & $2 \times 10$ & $10^{3}$ \\
& Refeições & & & \\
\hline \hline
\end{tabular}


Com relação aos alimentos que sofreram processamento térmico (tabela 14), notou-se um baixo crescimento bacteriano exceto nas amostras número 31 e 32 de coxinha de frango, 36 e 37 de cachorro quente e 38 de maionese. Todos estes produtos têm a característica de serem muito manipulados e não atingirem nem serem mantidos em temperatura adequada, daí a possibilidade de contaminação, principalmente pelo manipulador e da proliferação bacteriana pela manutenção em temperaturas inadequadas. No caso dos pastéis, até mesmo as amostras que estavam mantidas em temperatura ambiente, dentro de gavetas, antes da fritura, apresentaram crescimento baixíssimo para todos os microrganismos pesquisados. Isso comprova que as altas temperaturas da fritura são eficientes na eliminação dos mesmos. Os mesmos alimentos acima pesquisados provavelmente apresentariam resultados diferentes do observado se fossem pesquisadas a presença de esporos ou toxinas. Algumas bactérias tem capacidade de adquirir uma forma de resistência às condições não favoráveis à sua sobrevivência, denominada esporo e outras produzem toxinas durante a multiplicação. Os esporos e algumas toxinas são termorresistentes, e portanto não são destruídos pelo cozimento, fritura e outros processamentos térmicos. 


\section{CONCLUSÕES}

Quanto aos estabelecimentos de alimentos, conclui-se:

○ Foram encontrados 100 estabelecimentos de alimentos, entre bares, açougues, mercados, padarias, quitandas entre outros, tendo 66 sido submetidos a entrevista;

- a maioria dos entrevistados era do sexo masculino;

- os entrevistados tem baixo grau de escolaridade (Ensino fundamental completo ou incompleto em sua maioria);

- a maioria dos entrevistados tem acima de 30 anos;

- a maioria dos estabelecimentos são bares e botecos, considerados de baixa complexidade e existem há menos de 5 anos;

○ quase $50 \%$ dos entrevistados já trabalhou na área de alimentos anteriormente;

○ poucos comerciantes receberam algum tipo de treinamento na área de alimentos e um número ainda menor instrui seus funcionários com relação a higiene;

○ é necessário maior atenção aos estabelecimentos que realizam etapas de manipulação do alimento;

○ os comerciantes tem uma idéia mito vaga sobre os microrganismos;

○ deve ser elaborado um projeto educativo abordando as boas práticas em todas as etapas de produção do alimento, desde o fornecedor até a distribuição do mesmo, independente da possibilidade de realização de todas estas práticas no dia-a-dia; 
○ o que foi apontado como problemas na Comunidade devem ser usados a fim de iniciar um grupo de discussão para tentar resolver estes problemas, oportunidade que será aproveitada para inserir os conceitos de higiene alimentar;

○ a participação deve ser o eixo principal de qualquer projeto educativo;

Quanto aos moradores da Comunidade, observamos:

- A maioria dos entrevistados é do sexo feminino com idade entre 20 e 40 anos;

- os entrevistados preparam alimentos para o resto da família, incluindo crianças;

○ os entrevistados não sabem identificar quando um alimento está contaminado, apenas deteriorado;

○ pouco se sabe sobre os microrganismos e sobre os que são veiculados pelos alimentos;

○ existem muitas dúvidas que envolvem os alimentos e as doenças causadas pelos alimentos;

$\circ \quad$ o fato das pessoas não participarem em reuniões de associações ou outros grupos não significa que não haja interesse;

○ é preciso iniciar grupos de discussão abertos a debater questões de interesse da Comunidade;

○ a televisão é o meio mais utilizado pelos moradores para obter informação e pode ser explorado para abordar o tema higiene dos alimentos, sem esquecer a necessidade de participação ativa da comunidade na geração (inclusive)das informações; 
Com relação aos alimentos analisados, encontramos:

○ apenas uma amostra de alimento apresentou resultado fora dos padrões especificados por lei: queijo com altas concentrações de Staphylococcos aureus, representando risco real de intoxicação;

○ as amostras de carne bovina apresentaram altos valores de bactérias do grupo coliformes (fecais e totais), não estando, entretanto, desobedecendo aos padrões da legislação;

○ não foi encontrado valor considerável de microrganismos nas amostras de alimentos prontos para o consumo. Não sendo possível afirmar, no entanto que esses alimentos não apresentam nenhuma contaminação, uma vez que apenas alguns grupos de microrganismos foram pesquisados; 


\section{BIBLIOGRAFIA:}

ABDUSSALAM, M.; KÄFERSETEIN, F. K. Food safety: safety of street foods. World Health Forum v. 14, p.191-194, 1993.

ALTEKRUSE, S. F.; STREET, D. A.; FEIN, S. B.; LEVY,A. Consumer Knowledge of foodborne microbial hazards and food-handling practices. Journal of Food Protection, v. 59, n. 3, p. 287-294, 1995.

ANGELILLO, I. F.; FORESTA, M. R.; SCOZZAFAVA, C.; PAVIA, M. Consumers and foodborne diseases: knowledge, attittudes and reported bahavior in one region of Italy, International Journal of Food Microbiology, 64, p.161-166, 2001.

ASSOCIAÇÃO BRASILEIRA DE PROFISSIONAIS DA QUALIDADE DE ALIMENTOS-PROFIQUA Manual de boas práticas de fabricação para empresas processadoras de alimentos, Campinas: PROFIQUA, 1995, 4 ed.,24 p. (Manual-Série Qualidade).

ASSOCIAÇÃO BRASILEIRA DE PROFISSIONAIS DA QUALIDADE DE ALIMENTOS-PROFIQUA Higiene e sanitização para as empresas de alimentos, Campinas: PROFIQUA, 1995, 1 ed., 32p.(Manual-Série Qualidade).

ASSUMPÇÃO, E. G.; PICCOLI-VALLE, R. H.; HIRSCH, D. Fontes de contaminação por Staphylococcus aureus na linha de processamento de queijo prato. Arq. Bras. Med. Vet. Zootec., , v.55, n.3, p.366-370, 2003.

BALABAN, N.; RASOOLY, A. Review: Staphylococcal enterotoxins. International Journal of food Microbiology, 61, p. 1-10, 2001.

BRASIL, Métodos de análise microbiológica para alimentos. Ministério da Agricultura do Abastecimento e da Reforma Agrária, 1992.

BRASIL, Portaria Estadual CVS 06 de 10 de Março de 1999. Disponível em http://www.cvs.saude.sp.gov.br/legis.asp?classe=legis al2\&name=Alimentos Acesso em $15 / 05 / 2002$.

BRASIL, Portaria CVS 16 de 24 de Outubro de 2003. Disponível em: http://www.cvs.saude.sp.gov.br/03pcvs16.html Acesso em 01/11/2003.

BRASIL, Agência Nacional de Vigilância Sanitária (ANVISA) Resolução RDC n. 12 de 2 de Janeiro de 2001. Aprova o regulamento técnico sobre padrões microbiológicos para alimentos. Disponível em : $<\underline{\mathrm{http}}$ ://www.anvisa.gov.br/legis/resol/12 01rdc.htm. $>$ Acesso em: 21 de Outubro de 2002. 
BRASIL, Código de defesa do consumidor- Lei 8078/90, Rio de Janeiro: DP \& A, 2001.3 ed, p.11.

BRUHN, C. M. Consumer concerns: motivating to action. Emerging Infectious Diseases. v. 3, n. 4, 1997. Disponível em :

<http://www.cdc.gov/ncidod/eid/vol3no4/bruhn.htm> Acesso em :10 mar. 2001.

CALIFANO, A. N.; De ANTONI, L.; MASCHERONI, R. H. Prevalence of Unsafe Practices during home preparation of food in Argentina, Dairy Food and Environmental Sanitation, v. 20, n. 12, p. 934-943, Dec, 2000

DANIELS, R. W. Home food safety. Food technology, v. 52, n. 2, p. 54-52, Feb, 1998.

FEIN, S. B.; LIN, C.T.J.; LEVY, A.S. Foodborne Illness: Perceptions, experience and preventive behaviors in the United States. Journal of food protection, v. 58 n. 12, p. 1405-1411, Dec, 1995.

FEUERSTEIN, M. Avaliação:como avaliar programas de desenvolvimento com a participação da comunidade. São Paulo: Edições Paulinas, 1990, 184 p.

FOOD STANDARDS AGENCY Consumer attitudes to food standards- wave 2, London, 2002, $42 \mathrm{p}$.

FORSYTHE, S. J. Microbiologia da segurança alimentar. 1 ed, Porto Alegre: Artmed, 2002, $424 \mathrm{p}$.

FRANCO, R. M.; ALMEIDA, L. E. F. Avaliação microbiológica de queijo ralado, tipo parmesão, comercializado em Niterói, RJ. Revista Higiene Alimentar, São Paulo, v. 6, n. 21, p. 33-36. mar. 1992.

FRANCO, B. D. G. M.; LANDGRAF, M. Microbiologia dos alimentos. São Paulo: Atheneu, 1996,182 p.

FREIRE, P. Extensão ou comunicação? 11 ed., Rio de Janeiro: Paz e Terra, 1977, 93p.

FREIRE, P., Pedagogia do Oprimido, 30 ed., Rio de Janeiro: Paz e Terra, 2001, 184 p.

GERMANO, M. I. S. Promoção da saúde: desafio para os profissionais envolvidos no treinamento de manipuladores de alimentos. Tese (Doutorado em prática de saúde pública) Faculdade de Saúde Pública, Universidade de São Paulo, São Paulo, 2002 .

GERMANO, P. M. L.; GERMANO, M. I. S. Higiene e vigilância sanitária de alimentos. São Paulo: Varela, 2001, 629 p.

GIORDANO, J.C. Controle integrado de pragas em indústrias, hospitais e estabelecimentos comerciais: como e por quê contratar uma empresa controladora de 
pragas. In: CONGRESSO INTERNACIONAL DE CONTROLE DE VETORES E PRAGAS, 6.,2002, São Paulo. Anais... São Paulo: APRAG, 2002.

IBANHES, L. C. O setor informal urbano: a organização e as condições de saúde de um grupo de vendedores ambulantes. 1999. $344 \mathrm{f}$. Tese (Doutorado em prática de saúde pública) Faculdade de Saúde Pública, Universidade de São Paulo, São Paulo, 1999.

IGBEDIOH, S. O.; AKINYELE, I. O. What future for food control in developing countries? Some lessons from Nigeria. Ecology for Food Nutrition. v. 27, p. 127-132, 1992.

INSTITUTO PANAMERICANO DE PROTECIÓN DE ALIMENTOS Y ZOONOSIS Plan estrategico de protecion de alimentos. Disponível em:

$<$ http://<www.inppaz.org.ar>. Acesso em: 24 jan. 2001.

JÚNIOR, J. S. R.; BRANDÃO, S. C. C. Controle Industrial, garantia de qualidade e inspeção sanitária de produtos d origem animal: a responsabilidade dos setores privado e público. Revista Higiene Alimentar, São Paulo, v. 9, n. 40, p. 13-17, nov./dez. 1995.

KÄFERSTEIN, F.; ABDUSSALAM, M., Foood Safety in the 21st Century. Bulletin of the World Healyh Organization, v. 77, n. 4, p. 347-351, 1999.

KAFERSTEIN, F. K.; CLUGSTON, G. A. Human health problems related to meat production and consumption. Fleischwirtchaft, v. 75, n. 7, p. 889-892, 1995.

LERAYER, A. L. S. CARVALHO; A. F., BUCINE; A. KESTENER, B. M. A. C.; MOSQUIM, M. C. A.; NUTTI, M.R.; FILHO, P. S. Nova Legislação Comentada. São Paulo: Fonte comunicações, 1998, p. 100-101.

MALZYNER, C. Habitação, ambiente e saúde: diagnóstico de necessidades dos mutirantes da cidade de São Paulo- Região Leste 1. 2002. 152 f. Tese (doutorado em prática de saúde pública) Faculdade de Saúde Pública, Universidade de São Paulo, São Paulo, 2002.

MANNING, C. K. Food safety knowledge and attitudes of workers from institutional and temporary foodservice operations. Journal of the American Dietetic Association, v. 94 , n. 8, august 1994, p. 895-897.

MANUAL de elementos de apoio para o sistema APPCC. Rio de Janeiro: SENAC/DN, 2001, 282p (Qualidade e segurança alimentar).

MEAD, P. S.; SLUTSKER, L.; DIETZ, V.; McCAIG, L. F.; BRESEE, J. S.; SHAPIRO, C.; GRIFFIN, P. M.; TAUXE, R. Food-realated illness and death in the United States. Emerging Infectious Diseases, v. 5, n. 5 , p. 607-624, 1999.

MIGUEL, M.; LAMARDO, L. C. A.; GALVÃO, M. S.; NAVAS, S. A.; GARBELOTTI, M. L.; BRANCIFORTE,M. Legislação em higiene alimentar e suas aplicações . Revista Higiene Alimentar, São Paulo, v. 14 , n. 68/69, p. 107-114. Jan./ fev. 2000. 
MIWA, N.; KAWAMURA, A.; MASUDA, T.; AKIYAMA, M.; An outbreak of food poisoning due to egg yolk reaction-negative Staphylococcus aureus; International Journal of Food Microbiology 64, p.361-366, 2001.

MUSAIGER, A. O. Current situation of foodborne diseases in Bahrain: implications for prevention and control, Dairy Food and Environmental Sanitation, v. 15, n. 1, p. 2127, jan. 1995.

NIELLO, J. V. Papel das Comunidades na Proteção dos Alimentos, In: REUNIÃO INTERAMERICANA, A NÍVEL MINISTERIAL, SOBRE A SAÚDE E A AGRICULTURA, 12.,2001, São Paulo. Anais... São Paulo: Organização PanAmericana de Saúde, Organização Mundial da Saúde, 2001

OLIVAL, A. A.Avaliação da qualidade do leite de produtores do município de Pirassununga submetidos a um programa educativo.2002, 166 f. Dissertação (Mestrado em Nutrição Animal), Faculdade de Medicina Veterinária e Zootecnia, Universidade de São Paulo, São Paulo, 2002.

OLIVEIRA, M. K. Raciocínio e solução de problemas na vida cotidiana de moradores de uma favela. ENCONTROS DE PSICOLOGIA FACULDADE DE EDUCAÇÃO DA UNIVERSIDADE DE SÃO PAULO.1986, São Paulo, Anais... Departamento de Filosofia da Educação e Ciências da Educação, Universidade de São Paulo, 1986, 49p.

OLIVEIRA, S. P.; THÉBAUD-MONY, A. Hábitos e práticas alimentares em três localidades da cidade de São Paulo. Revista de Nutrição de Campinas, v. 11n. 1, p. 37-50, jan./jun, 1998.

OPAS/OMS, Estratégias para fomentar a promoção da proteção de alimentos através da participação comunitária, In: REUNIÃO INTERAMERICANA, A NÍVEL MINISTERIAL, SOBRE A SAÚDE E A AGRICULTURA, 12.,2001, São Paulo. Anais... São Paulo: Organização Pan-Americana de Saúde, Organização Mundial da Saúde, 2001

OPAS/OMS Notificação de surtos de DTA ao sistema de vigilância das doenças tranmitidas por alimentos (SIRVETA, 1999-2000), In: REUNIÃO INTERAMERICANA, A NÍVEL MINISTERIAL, SOBRE A SAÚDE E A AGRICUlTURA, 12.,2001, São Paulo. Anais... São Paulo: Organização PanAmericana de Saúde, Organização Mundial da Saúde, 2001.

ORGANIZAÇÃO MUNDIAL DA SAÚDE - Food safety an worldwide public health issue. Disponível em: <http:/www.who.int/fsf/fctshtfs.htm>. Acesso em: 24/jan./2001.

QUEIROS, R. P. V.; SANTOS,W. L. M.; BARBOSA, H. V.; SOUZA, R. M.; SANTOS FILHO, A. M. P. A importância do diagnóstico de cisticercose bovina. Revista Higiene Alimentar, São Paulo, v. 14, n. 77, p.12-15. out. 2000.

REICKS, M.; BOSCH,A.; HERMAN, M.; KRINKE, U.B. Efectiveness of a food safety teaching strategy promoting critical thinking. Journal of Nutrition Education, v. 26 n. 2, p.97-100, Mar-Apr 1994. 
SANTOS, M.B. Toxocaríase: avaliação do processo ensino-aprendizagem de recursos pedagógicos aplicados a crianças de ensino fundamental. 2003, $126 \mathrm{f}$. Dissertação (Mestrado em Epidemiologia experimental e Aplicada às Zoonoses), Faculdade de Medicina Veterinária e Zootecnia, Universidade de São Paulo, São Paulo, 2003.

SECRETARIA DA EDUCAÇÃO DO ESTADO DO CEARÁ; Educação Rural Integrada - A experiência de pesquisa e planejamento participativo no Ceará. Rio de Janeiro: Ed. Paz e Terra, 1983.

SESC, MESA SÃO PAULO: Ação contra a fome e o desperdício, pela qualidade de vida. São Paulo,1999, 98p)

SHEWMAKE, R., DILLN, B. Food Poisoning: causes, remedies and prevention. Postgraduate Medicine/ Food Poisoning v.103, n.6, June, 1998, p. 125-136.

SILVA, C. A.; SERAFINI, A. B. Análise microbiológica das refeições servidas no restaurante da Universidade Federal de Goiás, entre Junho e novembro de 1994. Revista Higiene Alimentar, São Paulo, v. 11, n. 48, p. 26-29, mar. /abr. 1997.

SILVA JÚNIOR, E. A. Manual de controle Higiênico-Sanitário dos alimentos. 3. ed. São Paulo: Varela, 1999. 397 p.

SOARES, I.O. Sociedade da Informação ou da Comunicação? São Paulo: Ed. Cidade Nova, 1996, 80 p.

TANAKA, M. M. S. Favela \& periferia. Estudos de recomposição urbana. 1993. 264 f. Tese (Doutorado em habitação-planejamento)- Faculdade de Arquitetura e Urbanismo, Universidade de São Paulo, São Paulo, 1993.

TASCHNER, S. P. Favelas e cortiços no Brasil: 20 anos de pesquisas e políticas. In: Cadernos de Pesquisa do LAP, n.18, São Paulo: Universidade de São Paulo, 1997. (Série Urbanização e Urbanismo), p. 11-27.

THIOLLENT, M. Metodologia da pesquisa-ação. 6 ed, São Paulo: Ed. Cortez, 1994, $107 \mathrm{p}$.

TOSIN, I.; MACHADO, R. A. Ocorrência de Campylobater spp entre manipuladores de alimentos em cozinhas hospitalares de localidade urbana da região Sul do Brasil. Rev. Saúde Pública, v.29, n.6, p.472-477, Dez 1995.

UDO, E. E.; AL-BUSTAN, M. A.; JACOB, L. E.; CHUGH, T. D. Enterotoxin production by coagulase-negative staphylococci in restaurant workers from Kwait City may be a potencial cause of food poisoning. Journal of Medical Microbiology, v.48, p.819-823, 1999.

UNGAR, L. M.; GERMANO, M. I. S.; GERMANO, P. M. L. Riscos e conseqüências da manipulação de alimentos para a saúde pública. Revista Higiene Alimentar, São Paulo, v. 6, n. 21, p. 14-17, mar, 1992. 
VALLA, V. V. Educação e favela. $1^{\text {a }}$ ed. Rio de Janeiro: Ed. Vozes, 1986. 212p.

VASCONCELOS, E. M., Educação popular e a atenção à saúde da família. 2 ed., São Paulo: HUCITEC, 2001. 336 p.

WHO, Microbial Contamination of street foods. 1996, 156 p.

WILLIAMSON, D. M.; GRAVANI, R. B.; LAWLESS, H. T. Correlating food-safety knowledge with home food preparation practices, Food Technology, p. 94-100, may 1992.

WOODBURN, M. J.; RAAB, C. A.; Household food prepare's food safety knowledge and practices following widely publicized outbreaks of foodborne illness. Journal of Food Protection, v. 60, n. 9, p. 1105-1109, 1997.

YANG, S.; LEFF, M. G.; McTAGUE, D.; HORVATH, K. A.; JACKSONTHOMPSON, J.; MURAYI, T.; BOESELAGUER, G. K.; MELNIK, T. A.; GILDEMASTER, M. C.; RIDINGS, D. L.; ALTEKRUSE, S. F.; ANGULO, F. J. Multistate surveillance for food handling, preparation, and consumption behaviorsassociated with foodborne diseases: 1995 and 1996 BRFSS Food -Safety questions. Surveillance sumaries, sep. 11, 1998. Disponível em :

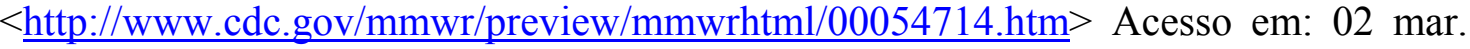
2001 .

ZACCARELli, E.; COELHO, H. D. S.; SILVA, M. E. P. O jogo, como prática educativa no treinamento para controle higiênico-sanitário, em unidades de alimentação e nutrição. Rev. Higiene Alimentar, v. 14, n. 70 p. 23-26, Março 2000. 
ANEXO A

ANEXOS

Questionário para os estabelecimentos:

Entrevistador: data / /2001 hora:

ATENÇÃO: CASO A PERGUNTA NÃO SE APLIQUE AO TIPO DE ESTABELECIMENTO VISITADO ESCREVA "NA".

Questionário para os proprietários de estabelecimentos:

Nome:

Sexo: Idade: Grau de instrução:

Nome do estabelecimento Endereço

Tipo de estabelecimento:

Bar( ) Lanchonete ( ) Restaurante( ) Mercado ( ) Açougue ( )

Outros ( ) ( especificar):

1.Há quanto tempo tem o comércio?

2.Já trabalhou com alimentos anteriormente?

( ) $\operatorname{Sim}$

( ) Não

Onde?/há quanto tempo?

3.É a única fonte de renda da família?

( ) $\operatorname{Sim} \quad$ ( ) Não

4.Quantos funcionários trabalham no estabelecimento?

Destes, quantos são familiares?

5.Quais produtos são comercializados?

6.a)Costuma ler o rótulo dos produtos?

( ) $\operatorname{Sim} \quad$ ( ) Não

b)O que você vê? ( )data de validade ( )composição

( ) outros

7.a) De onde vem a matéria -prima que você utiliza?

( ) fornecedores ( ) sai para comprar (onde?)

a) O que você observa quando vai adquirir um produto?

(como decide entre dois, por ex)

c) Já precisou devolver matéria -prima? ( ) Sim

( ) Não

por quê? 
8. Já recebeu algum tipo de treinamento ou instrução sobre a manipulação de alimentos?

( ) Sim ( ) Não Onde, quando?

9.Você passa algum tipo de instrução para os seus funcionários? Qual?

( ) Sim ( ) Não Qual?

10.Acha que a falta de higiene ao preparar os alimentos pode provocar doenças ou malestar nas pessoas?

( ) Sim ( ) Não

a)O que você considera falta de higiene ?

( ) não lavar as mãos ( )não guardar na geladeira ( )não cozinhar direito

( ) outros

11.Qual o principal cuidado que você toma ao manipular o alimento?

12.Você tem muita perda com alimentos estragados? ( ) Sim （ ） Não

a)O que faz para evitar que eles estraguem?

( ) guardo na geladeira ( ) guardo no freezer

( ) outros

13.Já observou ratos e /ou baratas em seu estabelecimento?

( ) $\operatorname{Sim}$ ( ) Não

O que fez?

14.Que produto usa para lavar seus utensílios? E o piso?

a)Com que freqüência o piso é lavado?

( ) todo o dia ( ) após o uso ( ) semanalmente ( )outros

15.Há banheiros no estabelecimento?

( ) $\operatorname{sim}($ ) não Quantos?

16. Qual é a freqüência de limpeza nos banheiros?

Qual (is) produto(s) utilizados na limpeza

17. Já ouviu falar em micróbios ou bactérias?

( ) $\mathrm{Sim}$

( ) Não

a) Você acha que eles(as) estão ( ) no solo ( ) na água ( ) nos animais ( ) na pele ( ) nos alimentos ( ) outros

PERGUNTAR SOBRE TODOS!

b) Como você acha que pode destruí-los? ( ) cozinhando os alimentos

( ) resfriando-os ( ) lavando as mãos ( ) fervendo a água

( ) lavando o chão( ) outros

PERGUNTAR SOBRE TODOS! 
c)Quando você pensa em bactérias, qual palavra vem na sua cabeça?

18.Existe algum tipo de associação entre os comerciantes da comunidade? Fazem reuniões?

( ) Sim ( ) Não

19.Quais problemas o comerciante enfrenta na comunidade?

20.Para você, qual é a solução?

21. Se você pudesse mudar alguma coisa no estabelecimento, o que mudaria? Por que?

22. Gostaria de saber mais sobre a qualidade dos alimentos conversando com um profissional?

( ) $\operatorname{Sim}$ ( ) Não

23.Você sabe qual é o profissional que pode informar a respeito da qualidade e higiene com os alimentos?

( ) Não

24. Já ouviu falar da Legislação para estabelecimentos de alimentos?

( ) $\operatorname{Sim} \quad$ ( ) Não

a) tem acesso a elas? ( ) Sim ( ) Não

25.Alguma vez foi vistoriado pela vigilância sanitária?

( ) $\operatorname{Sim} \quad$ ( ) Não

a) Se sim, quantas vezes/o que achou?

26. Sabe para que serve a análise dos alimentos?

27. Gostaria de analisar algum alimento ? ( ) Sim ～( ) Não

Tipo: autorizou?:

OBSERVAÇÕES (espaço livre para comentários de toda natureza): 


\section{ANEXO B}

\section{Questionário para a população:}

Entrevistador: data:

Nome: Endereço: no.

Sexo: Idade: Ocupação:

Estudou até que ano:

1. Quantas pessoas moram na casa? (idades/parentesco)

2. Quem cozinha na casa? ( )Ele/ela mesmo(a) ( ) outro

3. Cozinha em média para quantas pessoas?

4. Quantas vezes por semana? ( ) todos os dias ( ) dia sim, dia não

( )outra opção

5. Que comida que você mais faz?

6. Onde você compra os alimentos? ( ) supermercado ( ) venda

( ) outros

7. E a carne, o leite? ( e outros produtos de origem animal)

8. Costuma olhar o rótulo dos produtos? (Quando compra ou em casa)

( ) $\operatorname{sim}($ ) Não

a)O que você vê? ( ) data de validade ( ) composição

( ) algo mais? outros

9. Já teve que jogar fora ou trocar alguma mercadoria? ( ) sim ( ) Não

Qual foi o motivo?

10. Você compra os alimentos pra durarem quanto tempo?

( )a semana ( )o dia ( )o mês ( ) depende

11. Você tem muita perda com alimento estragado? ( ) $\operatorname{sim}(\quad)$ Não

12. Por que você acha que os alimentos estragam?

13. O que você faz para evitar que estraguem?

14. Você acha que alguns estragam mais rápido que outros? ( ) sim ( ) Não Quais, por exemplo e por quê?

15. O que você considera como falta de higiene na hora de cozinhar? 
16. Que conseqüências isso pode trazer?

17. Já passou mal ao ingerir alimento? ( ) sim ( ) Não

Se sim, onde foi , qual alimento ingeriu e quais sintomas apresentou?

ONDE QUAL

SINTOMAS

18. Você precisou ir ao médico? ( ) sim ( ) Não

Por Quê?

19. Já ouviu falar em micróbios e bactérias? ( ) sim ( ) Não

20. Qual a primeira palavra que te vem na cabeça quando pensa em bactéria?

21.Onde você acha que elas estão? ESPERAR A RESPOSTA E DEPOIS PERGUNTAR UM POR UM.

( ) no chão ( ) na água ( ) nos alimentos ( ) nos animais ( ) nas nossas mãos ANOTAR OS COMENTÁRIOS!

22. Com elas podem ser destruídas? ASSOCIAR COM A QUESTÃO ANTERIOR

( )Calor (aquecendo os alimentos) ( ) colocando na geladeira (frio) ( ) produtos de limpeza (para o chão) ( ) lavando as mãos ( ) fervendo a água

( )outros

23. Você acha que o alimento pode estar estragado sem ter nenhuma alteração visível? ( ) $\operatorname{sim}($ ) Não Por que?

24. Qual o principal cuidado que você tem na hora de cozinhar?

25. Qual destes procedimentos é o mais importante na hora de cozinhar?

( ) lavar as mãos ( ) colocar um avental ( ) prender o cabelo ( )outro

Por que de cada resposta, do sim ou do não:

26. Conhece alguma doença transmitida pelos alimentos?

( ) $\operatorname{sim}($ )Não Qual? (Qual alimento?)

27. Conhece alguém que já teve alguma dessas? ( ) sim ( ) Não

Quem? Como?

28. Sabe como evitar? ( ) sim ( ) Não Como?

29. Qual alimento você considera mais perigoso ( que pode transmitir doenças) e POR QUE?

30. Na sua opinião, para que serve a geladeira?

( ) para os alimentos não estragarem ( ) para guardar a comida

( ) para gelar o alimento ( ) outros 
31. Costuma freqüentar algum tipo de grupo ou associação que discute os problemas da comunidade?

( ) Sim ( ) Não Por que não?

a) Que tipo? ( ) igreja ( ) escola ( ) associação de moradores

( ) outros

b)Quais os problemas discutidos?

c) Acha que as discussões produzem algum resultado?

( ) $\operatorname{Sim}$ ( ) Não

d)Por quê?

32. O que você considera como o principal(is) problema(s) na sua comunidade?

Quais são, para você, as soluções?

33. Qual é o seu meio principal de obter informação?

( ) televisão(CANAL) ( ) rádio (QUAL) （）JORNAL DA COMUNIDADE

( ) Jornal (QUAL) （ ) Nenhum

( ) outros

34. Você gostaria de saber mais sobre esse assunto(alimentos)?

( ) Sim ( ) Não Algo em especial?

35. Quem você acha que é a pessoa ( profissional) indicado para falar sobre este assunto? ( ) não sei

Resposta livre: Por quê?

36. Qual seria a melhor forma?

( )cartilha ( ) palestra ( ) cartazes ( )teatro ( ) programa de rádio ou TV

( ) outros

Observações de qualquer natureza, (o entrevistado, a situação, impressões, etc) 
ANEXO C

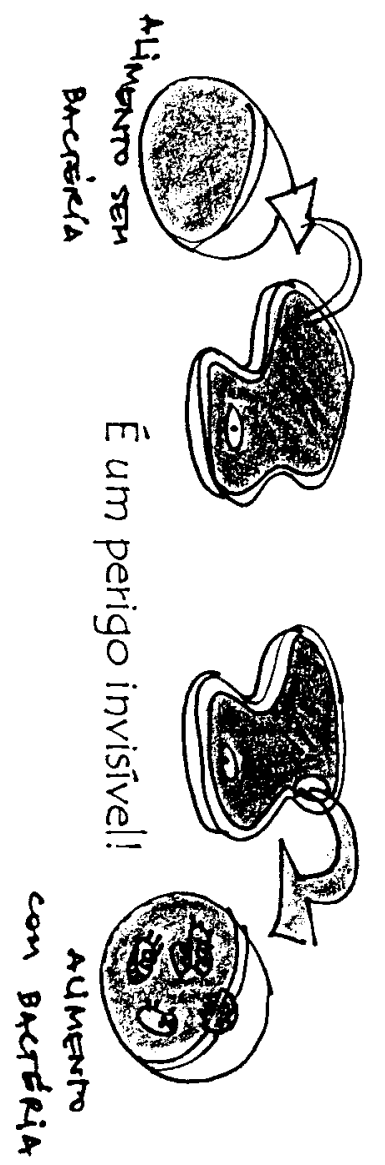

ento

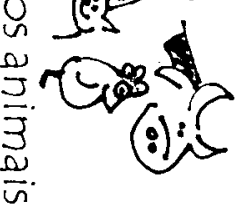

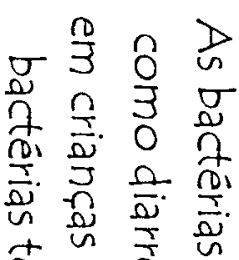

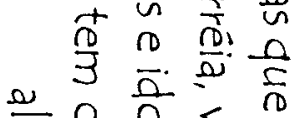

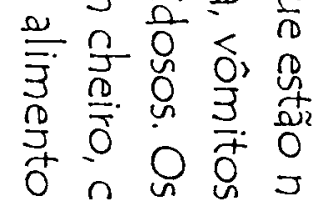

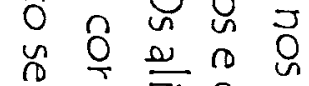

\begin{tabular}{ccccc}
3 & 0 & $\overline{3}$ & 0 & 0 \\
\hline & 0 & 0 & 0 & $\overline{3}$
\end{tabular}

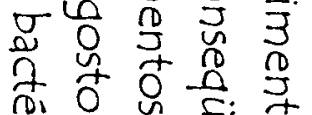

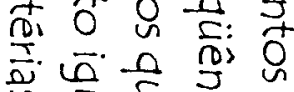

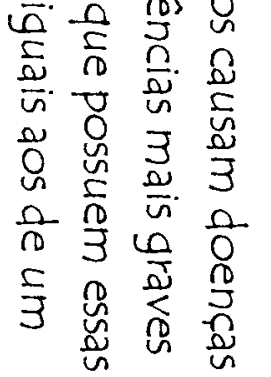

مै
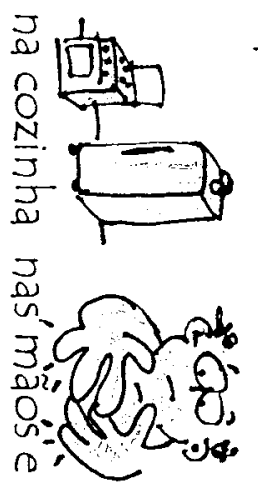

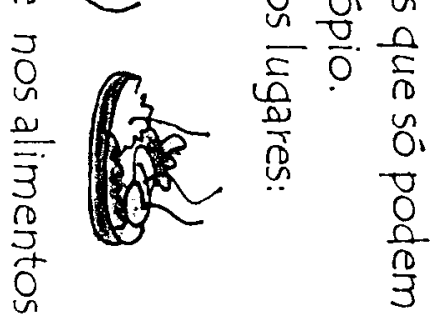

3

8 品 $\frac{1}{\Gamma}$

की ०ी 0

103 प 0

$\frac{\bar{n}}{\frac{0}{5}} \frac{0}{\frac{1}{5}}$

․․․ $\frac{0}{21}$

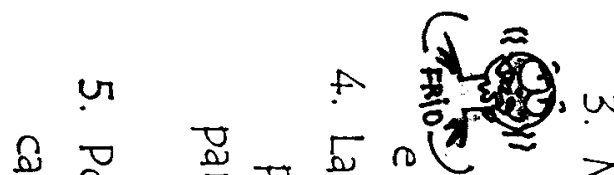

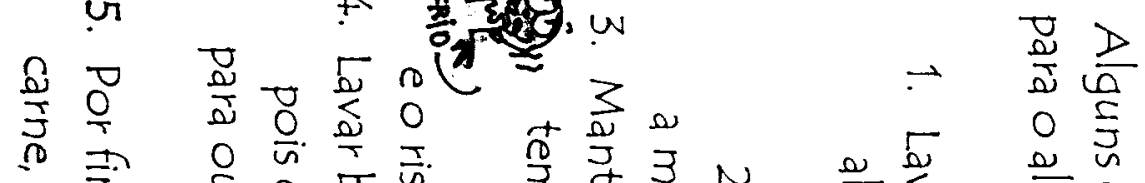

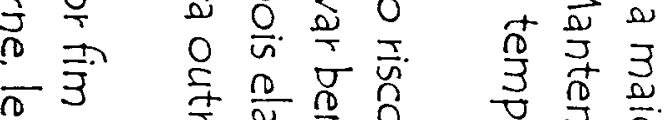

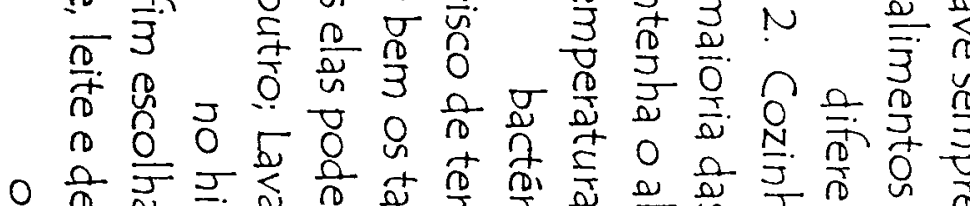

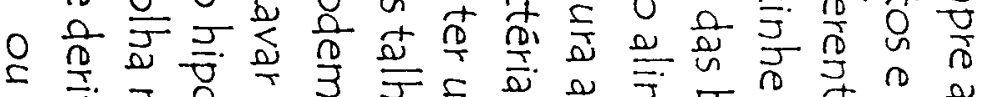

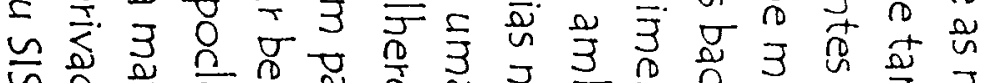

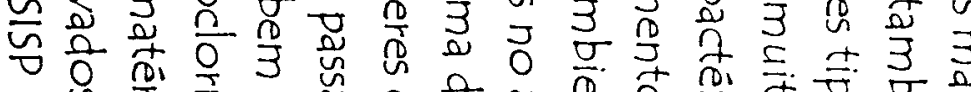

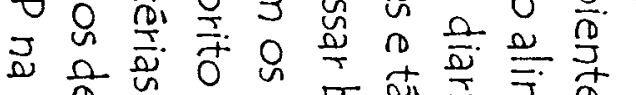

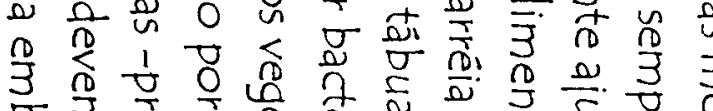

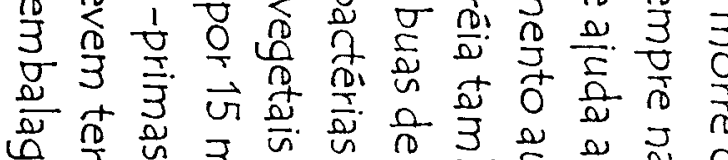

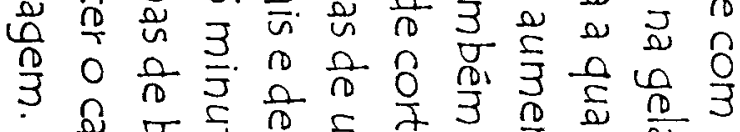

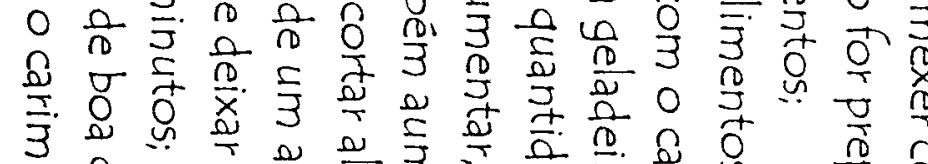

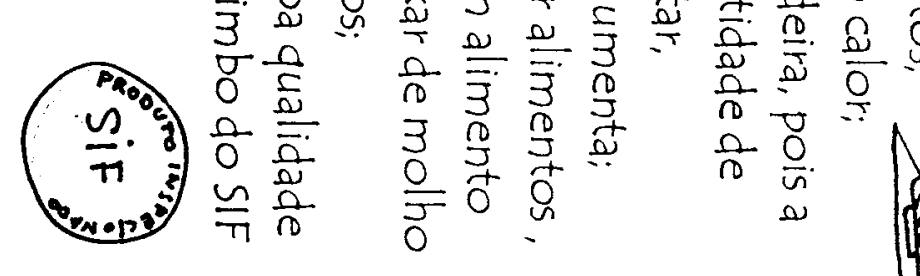

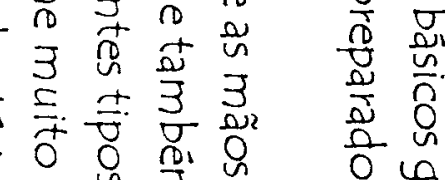

今

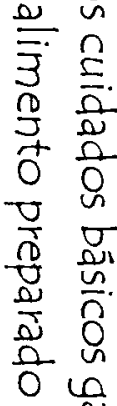

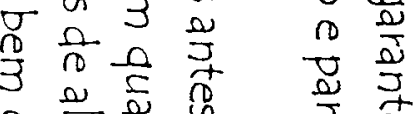

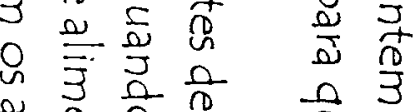

8

A1 